The University of Washington Press is the oldest and largest publisher of scholarly and general interest books in the Pacific Northwest.

We publish compelling and transformative work with regional, national, and global impact. We are committed to the idea of scholarship as a public good and work collaboratively with our authors to produce books that meet the highest editorial and design standards. We value and promote equity, justice, and inclusion in all our work.

\section{PUBLISHER FOR THE UNIVERSITY OF WASHINGTON}

The press serves the research, education, and outreach missions of the University of Washington by publishing vital new work for an international community of scholars, students, and intellectually curious readers.

\section{PUBLISHING PROGRAM}

We publish books in the following core academic areas:

American Studies

Anthropology

Art History / Visual Culture

Asian American Studies

Asian Studies

Critical Ethnic Studies

Environmental History

Native American and Indigenous Studies

US History

Women's, Gender, and Sexuality Studies

We also publish vibrant nonfiction about the Pacific Northwest and beyond, often in partnership with museums, cultural organizations, and Indigenous nations and communities.

\section{SUPPORT THE PRESS!}

We rely on generous gifts and grants from individuals and foundations to publish the books you see in this catalog and on our website. Partner with us by making a tax-deductible gift. For information about ways to give, please contact Nicole Mitchell at nfmm@uw.edu or make a gift online at www.uw.edu/giving/uwpress.

\section{W \\ UNIVERSITY of WASHINGTON}

\section{UNIVERSITY LIBRARIES}

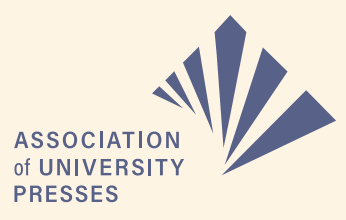

The University of Washington Press is a founding member of the Association of University Presses.

FRONT COVER: Women's deer-hide dance dress, with abalone pendants and shell decoration, Lane family home, Siletz, Oregon, 2016. Photograph by Frank Miller. Courtesy of Frank Miller and Willamette University.

BACK COVER: Japanese laborers working at a loading ramp, Pacific National Lumber Company, early twentieth century. University of Washington Libraries, Special Collections, C. Kinsey 2609. 


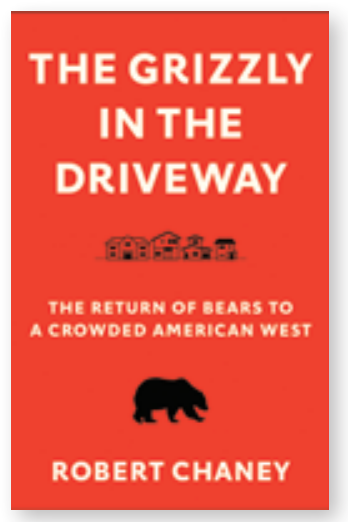

The Grizzly in the Driveway The Return of Bears to a Crowded American West

Robert Chaney

FIRST HONORABLE MENTION FOR THE 2021 RACHEL CARSON ENVIRONMENT BOOK AWARD, SOCIETY OF ENVIRONMENTAL JOURNALISTS

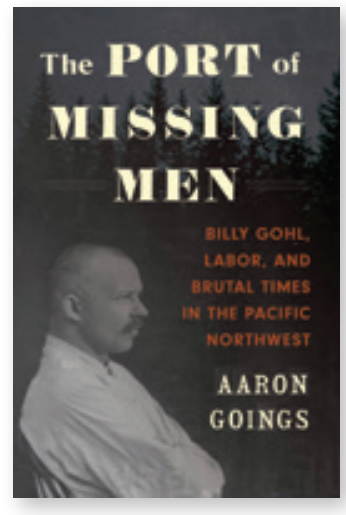

The Port of Missing Men

Billy Grohl, Labor, and Brutal Times in the Pacific Northwest

Aaron Coings

WINNER OF THE 2021 SALLY AND KEN OWENS AWARD FOR BEST BOOK ON THE HISTORY OF THE PACIFIC WEST, WESTERN HISTORY ASSOCIATION

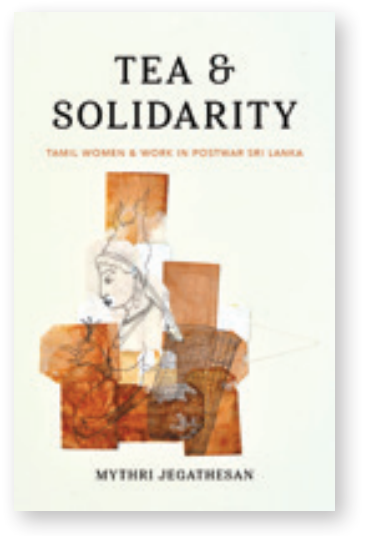

Tea and Solidarity

Tamil Women and Work in Postwar Sri Lanka

Mythri Jegathesan

WINNER OF THE 2021 MICHELLE Z. ROSALDO BOOK PRIZE IN FEMINIST ANTHROPOLOGY, ASSOCIATION OF FEMINIST ANTHROPOLOGY

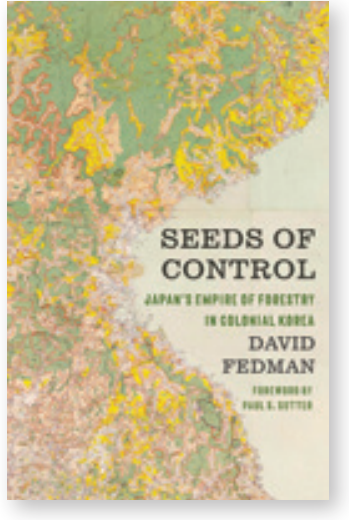

\section{Seeds of Control}

Japan's Empire of Forestry in Colonial Korea

David Fedman

WINNER OF THE 2021 CHARLES A. WEYERHAEUSER BOOK AWARD, FOREST HISTORY SOCIETY

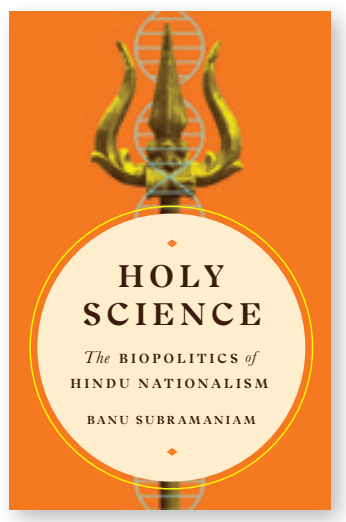

\section{Holy Science}

The Biopolitics of Hindu Nationalism Banu Subramaniam

WINNER OF THE 2020 SLSA MICHELLE KENDRICK MEMORIAL BOOK PRIZE, SOCIETY FOR LITERATURE, SCIENCE, AND THE ARTS 

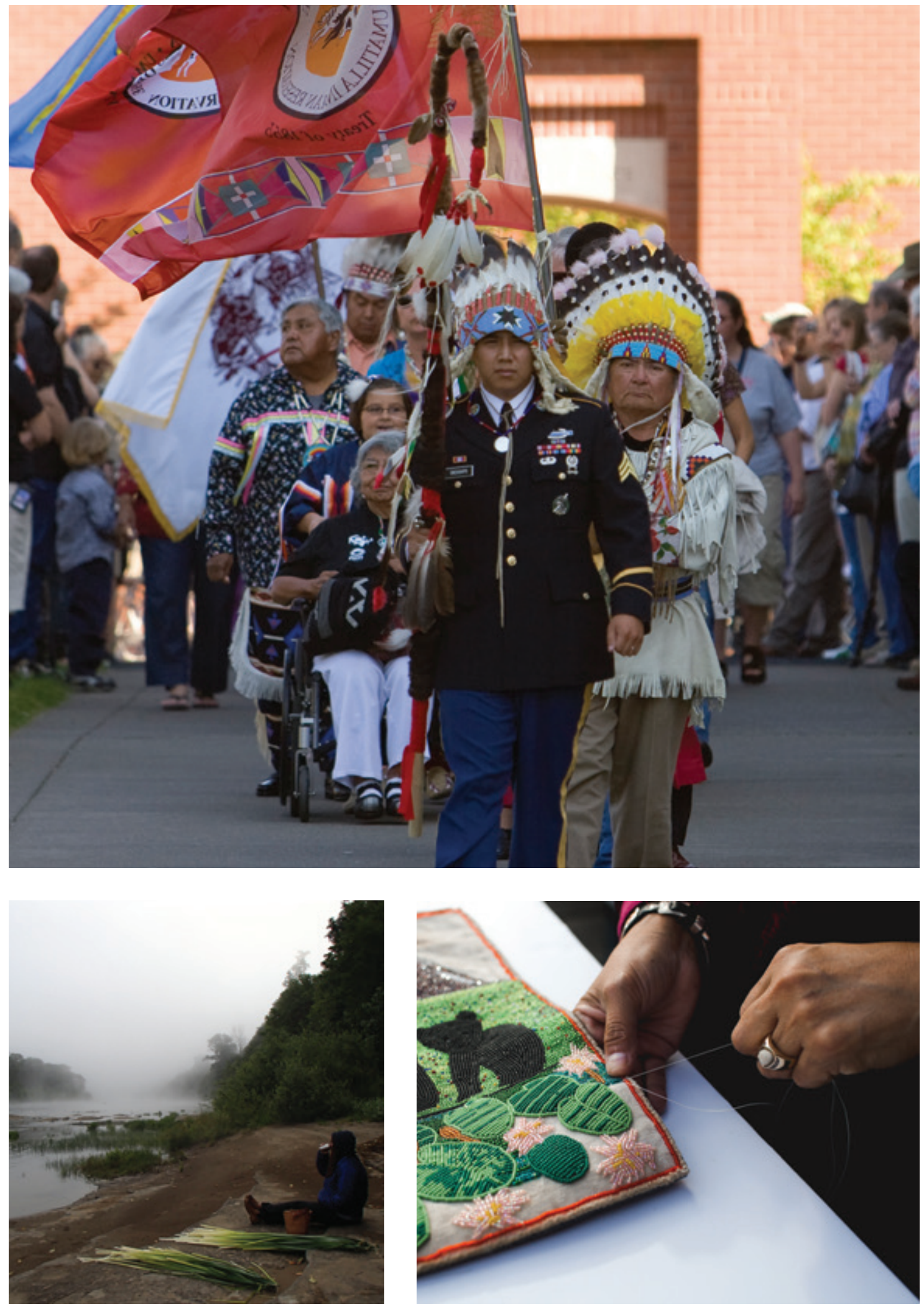


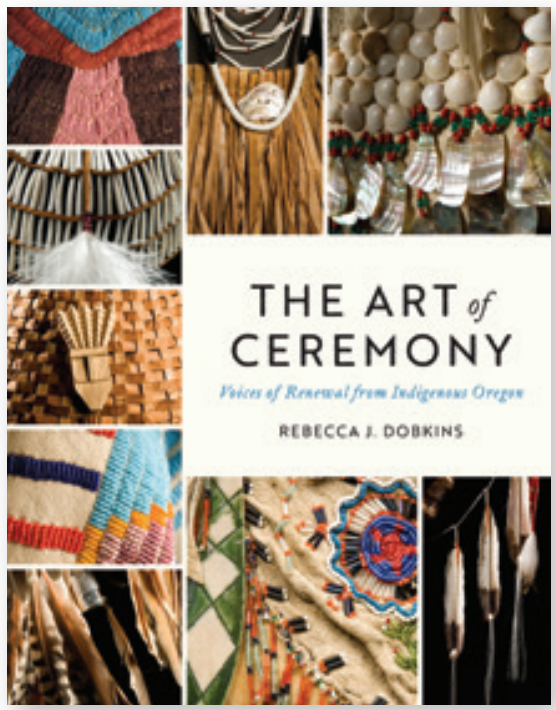

\title{
The Art of Ceremony
}

\author{
Voices of Renewal from Indigenous Oregon
}

Rebecca J. Dobkins

CELEBRATES THE POWER OF INDIGENOUS RENEWAL

THROUGH CEREMONY

NATIVE AMERICAN AND INDIGENOUS ART | PACIFIC NORTHWEST

$\$ 99.00 x$ / £79.00 HC / ISBN 9780295750309

$\$ 34.95$ / £26.99 PB / ISBN 9780295750668

$\$ 34.95$ / £26.99 EB / ISBN 9780295750316

FOR TWENTY-FIRST CENTURY OREGON TRIBES, CEREMONY involves renewing and building relationships between and among the land and its beings, work that reflects constant change even as it draws upon deep relationships going back millennia. Ceremony may involve intricate and spectacular regalia as well as simple tools such as a plastic bucket for harvesting huckleberries or a river rock that holds heat for sweat. The Art of Ceremony offers rich conversations with members of the nine federally recognized tribes in Oregon, who share their commitments to ceremonial practices that are inextricably linked to language, art, kinship relations, ecological systems, and political and legal sovereignty.

Vivid photographs illuminate the ties between land and people at the heart of such practice, and each chapter features specific ceremonies chosen by tribal co-collaborators, such as the Siletz Nee Dosh (Feather Dance), the huckleberry gathering of the Cow Creek Umpqua, and the Klamath Return of C'waam (sucker fish) Ceremony. Part of a larger global story of Indigenous rights and cultural resurgence in the twenty-first century, The Art of Ceremony celebrates the power of Indigenous renewal, sustainable connection to the land, and the ethics of responsibility and reciprocity between the earth and all its inhabitants.

Rebecca J. Dobkins is curator at the Hallie Ford Museum of Art and professor of anthropology at Willamette University and coauthor of Crow's Shadow Institute of the Arts at 25.
"A beautifully facilitated gathering of Tribes of Oregon in a book that is itself a kind of ceremony, honoring the regalia alongside many responsibilities, relationships, and rights that Tribes renew each year."

-BROOK COLLEY (Wasco/Warm Springs/Eastern Cherokee, Enrolled Eastern Band of Cherokee Indians), Southern Oregon University

"Weaves a strong argument about the historical and contemporary effects of unequal power relations on Oregonian tribes and the resulting push for Indigenous resurgence and selfgovernance."-]ENNIFER KRAMER, University of British Columbia

JACOB LAWRENCE SERIES ON AMERICAN ARTISTS

\section{A HELEN MARIE RYAN WYMAN BOOK}

JULY

280 pp., 123 color illus., $7.25 \times 9$ in. 


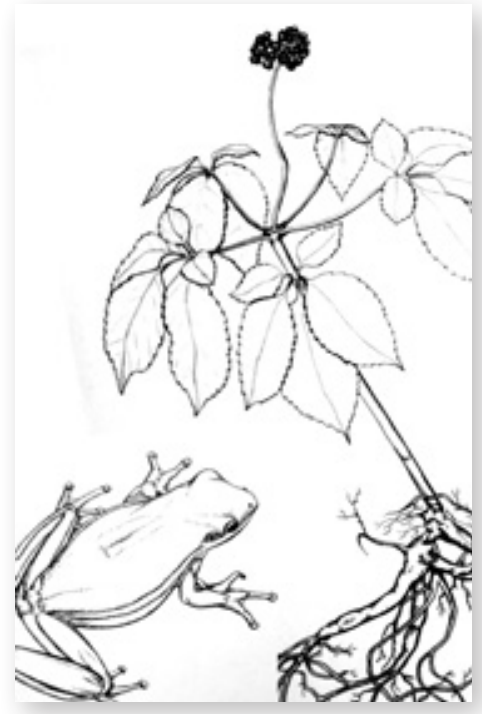

\title{
Cherokee Earth Dwellers
}

\author{
Stories and Teachings of the Natural World
}

\section{Christopher B. Teuton and Hastings Shade}

With Loretta Shade and Larry Shade

A RICH PORTRAIT OF THE CHEROKEE COSMOS

AND ALL OF ITS LIFE FORMS

NATIVE AMERICAN AND INDIGENOUS STUDIES | NATURE AND ENVIRONMENT $\$ 99.00 x$ / f79.00 HC / ISBN 9780295750163 $\$ 34.95$ / £26.99 PB / ISBN 9780295750187

$\$ 34.95$ / £26.99 EB / ISBN 9780295750194

AYETLI GADOGV-TO "STAND IN THE MIDDLE"-IS AT THE heart of a Cherokee perspective of the natural world. From this stance, Cherokee Earth Dwellers offers a rich understanding of nature grounded in Cherokee creature names, oral traditional stories, and reflections of elders and knowledge holders. During his lifetime, elder Hastings Shade created booklets with over six hundred Cherokee names for animals and plants. With this foundational collection at its center, and weaving together a chorus of voices, this book emerges from a deep and continuing collaboration between Christopher B. Teuton, Hastings Shade, Loretta Shade, and others.

Positioning our responsibilities as humans to our more-thanhuman relatives, this book presents teachings about the body, mind, spirit, and wellness that have been shared for generations. From clouds to birds, oceans to quarks, this expansive Cherokee view of nature reveals a living, communicative world and humanity's role within it.

Christopher B. Teuton (Cherokee Nation) is professor of American Indian Studies at the University of Washington. He is author of Cherokee Stories of the Turtle Island Liars' Club. Hastings Shade (1941-2010) was deputy chief of the Cherokee Nation (1999-2003) and named a Cherokee National Treasure in 1991. Loretta Shade (1946-2021) was a master-level speaker of the Cherokee language and named a Cherokee National Treasure in 2018. Larry Shade (Cherokee Nation) is an educator and cultural traditionalist.
"A collaborative effort rooted in Indigenous thought, Cherokee Earth Dwellers shares knowledge of our world as a relational realm that includes humans but does not center them. Works like this are direly needed to counteract an increasing global deficiency in ecological morality." - CLINT CARROLL (Cherokee Nation), University of Colorado Boulder

"With signature wit and clarity, Teuton and Shade help Cherokee people to practice Keetoowah ways in and through our language. These are the Keetoowah teachings we need at just the right time."-ELLEN CUSHMAN (Cherokee Nation), Northeastern University

SUPPORTED BY THE JILL AND JOSEPH MCKINSTRY BOOK FUND

AUGUST

320 pp., 66 b\&w illus., $7 \times 10$ in. 


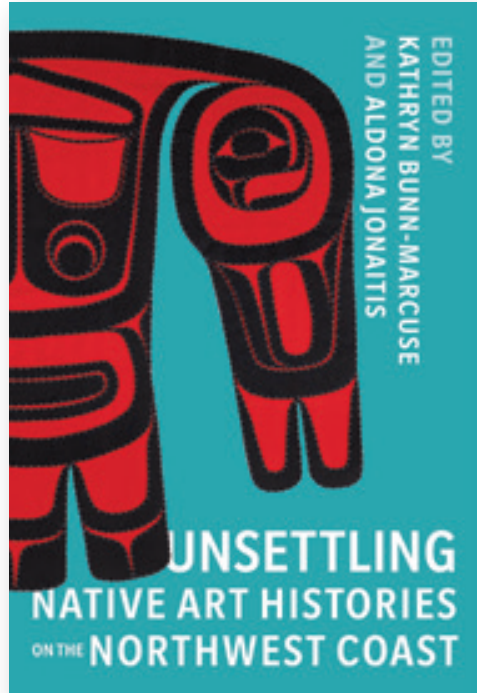

\title{
Unsettling Native Art Histories on the Northwest Coast
}

\author{
Edited by Kathryn Bunn-Marcuse and Aldona Jonaitis \\ NEW ESSAYS ACKNOWLEDGE NATIVE AUTHORITY, INDIGENIZE \\ CULTURAL NARRATIVES, AND DISRUPT THE COLONIALIST LECACY
}

NATIVE AMERICAN AND INDIGENOUS ART | PACIFIC NORTHWEST

$\$ 29.95$ / £22.99 PB / ISBN 9780295750705

INSEPARABLE FROM ITS COMMUNITIES, NORTHWEST COAST art functions aesthetically and performatively beyond the scope of non-Indigenous scholarship, from demonstrating kinship connections to manifesting spiritual power. Contributors to this volume foreground Indigenous understandings in recognition of this rich context and its historical erasure within the discipline of art history.

By centering voices that uphold Indigenous priorities, integrating the expertise of Indigenous knowledge holders about their artistic heritage, and questioning current institutional practices, these new essays "unsettle" Northwest Coast art studies. Key themes include discussions of cultural heritage protections and Native sovereignty; re-centering women and their critical role in transmitting cultural knowledge; reflecting on decolonization work in museums; and examining how artworks function as living documents. The volume exemplifies respectful and relational engagement with Indigenous art and advocates for more accountable scholarship and practices.

Kathryn Bunn-Marcuse is director of the Bill Holm Center for the Study of Northwest Native Art, curator of northwest Native art at the Burke Museum, assistant professor of art history at the University of Washington, and coeditor of In the Spirit of the Ancestors. Aldona Jonaitis is former director of the University of Alaska Museum of the North, professor of anthropology at the University of Alaska Fairbanks, and author of Art of the Northwest Coast.

Contributors: Karen Benbassat Ali, Janet Catherine Berlo, Iljuuwaas Tyson Brown (Haida Nation), Jisgang Nika Collison (Haida Nation), Karen Duffek, Sharon Fortney (Klahoose), Christopher Green, Denise Nicole Green, Ishmael Hope (Inupiaq and Tlingit), Lily Hope (Tlingit), Kaitlin McCormick, Emily Moore, Peter Morin (Tahltan Nation), Lou-ann Ika’wega Neel (Kwakwakka'wakw), Duane Niatum (Jamestown S'Klallam), Megan Smetzer, Robert Starbard (Xunaa Tlingit), Evelyn Vanderhoop (Haida Nation), and Lucy Fowler Williams.

\section{NATIVE ART OF THE PACIFIC NORTHWEST: A BILL HOLM CENTER SERIES}

SUPPORTED BY THE JILL AND JOSEPH MCKINSTRY BOOK FUND

\section{MARCH}

344 pp., 121 color illus., $7 \times 10$ in. 

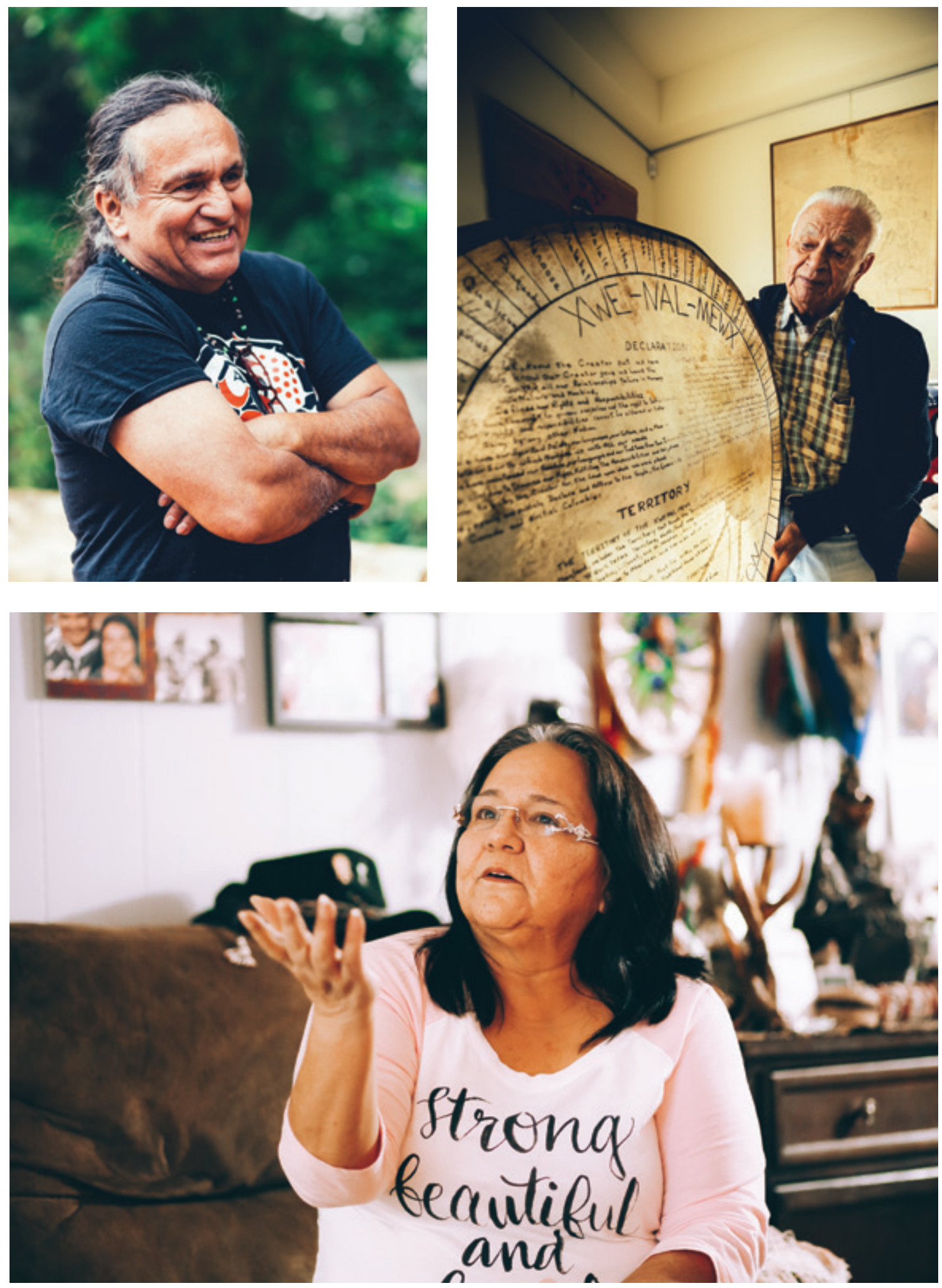


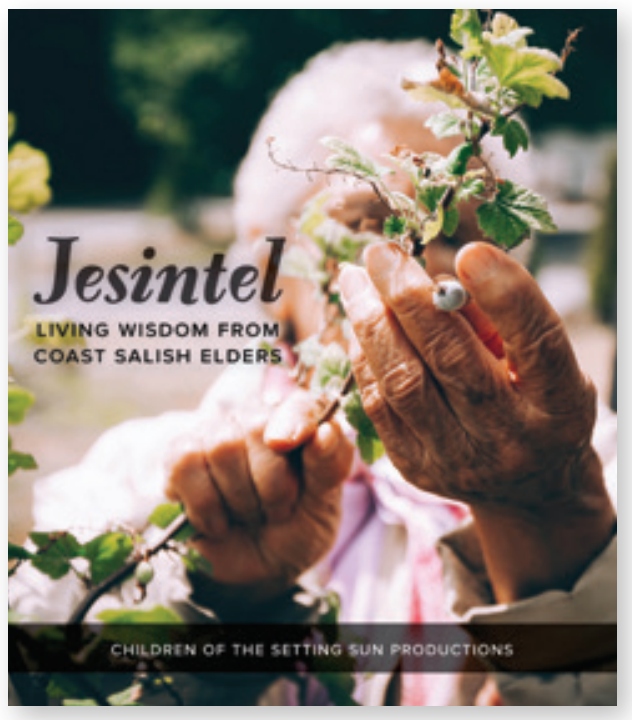

\section{Jesintel}

Living Wisdom from Coast Salish Elders

Children of the Setting Sun Productions

Edited by Darrell Hillaire and Natasha Frey

Photographs by Fay "Beau" Garreau Jr.

A GATHERING OF STORIES FOR ALL GENERATIONS, PAST, PRESENT, AND FUTURE

NATIVE AMERICAN AND INDIGENOUS STUDIES | BIOCRAPHY | PACIFIC NORTHWEST

$\$ 34.95$ / £26.99 PB / ISBN 9780295748641

$\$ 34.95$ / £26.99 EB / ISBN 9780295748658
DYNAMIC AND DIVERSE, COAST SALISH CULTURE IS CONNECTED BY shared values and relations that generate a resilient worldview. Jesintel- "to learn and grow together" - characterizes the spirit of this book, which brings the teachings of elders to new generations.

Featuring interviews that share powerful experiences and stories, Jesintel illuminates the importance of ethical reciprocal relationships and the interconnectedness of places, land, water, and the spirit within all things. Elders offer their perspectives on language revitalization, Coast Salish naming practices, salmon, sovereignty, canoe racing, and storytelling. They also share traumatic memories, including of their boarding school experiences and the epidemics that ravished their communities. Jesintel highlights the importance of maintaining relations and traditions in the face of ongoing struggles and honors the boundless relations of Coast Salish people and their territories.

Children of the Setting Sun Productions (CSSP) is a Native-owned and -operated production company headquartered in Bellingham, Washington. Darrell Hillaire (Lummi) is executive director of CSSP, and Natasha Frey is principal of Setting Sun Institute, a subsidiary of CSSP. Fay "Beau" Garreau Jr. is Hunkpapa and Mnicoujou Lakota and a member of the Cheyenne River Sioux Tribe and runs DaKO.5TUDIOS. Includes contributions by Lynda V. Mapes of the Seattle Times and Nicole Brown, associate professor at Western Washington University. Danita Washington (Lummi) contributed an afterword.
"A beautiful sharing of thriving Coast Salish communities. Indigenous elders, cultures, and languages have so much precious wisdom to share, and Jesintel celebrates these through storytelling and photos. It is a generous gift to anyone who wants to better understand the resilience of Indigenous communities." -Michelle M. JAсов (Yakama), author of The Auntie Way: Stories Celebrating Kindness, Fierceness, and Creativity

SUPPORTED BY THE JILL AND JOSEPH MCKINSTRY BOOK FUND

JULY

304 pp., 144 color illus., 1 map, $9 \times 10$ in. 


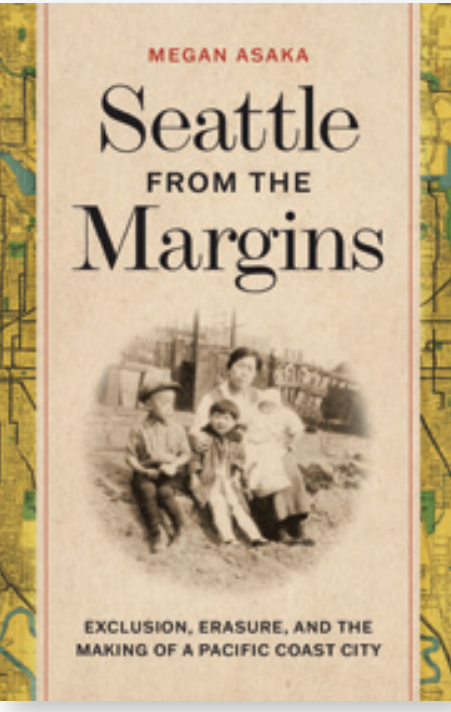

\title{
Seattle from the Margins
}

\author{
Exclusion, Erasure, and the Making of a Pacific Coast City \\ Megan Asaka
}

UNCOVERS THE ERASED HISTORIES OF COMMUNITIES THAT

BUILT SEATTLE

PACIFIC NORTHWEST | HISTORY; ASIAN AMERICAN STUDIES

$\$ 29.95$ / £22.99 HC/ ISBN 9780295750675

$\$ 29.95$ / £22.99 EB / ISBN 9780295750682

FROM THE ORIGINS OF THE CITY IN THE MID-NINETEENTH century to the beginning of World War II, Seattle's urban workforce consisted overwhelmingly of migrant laborers who powered the seasonal, extractive economy of the Pacific Northwest. Though the city benefitted from this mobile labor force that consisted largely of Indigenous peoples and Asian migrants, municipal authorities, elites, and reformers continually depicted these workers and the spaces they inhabited as troublesome and as impediments to urban progress. Today the physical landscape bears little evidence of their historical presence in the city.

Tracing the histories of unheralded sites such as labor camps, lumber towns, lodging houses, and so-called slums, Seattle from the Margins shows how migrant laborers worked alongside each other, competed over jobs, and forged unexpected alliances within the marine and coastal spaces of the Puget Sound area. By uncovering the historical presence of marginalized groups and asserting their significance in the development of the city, Megan Asaka offers a deeper understanding of Seattle's complex past.

Megan Asaka is assistant professor of history at the University of California, Riverside.
"Asaka's rigorous examination of Native, Chinese, and Japanese experiences and their relationship to a larger history of racial contestation and displacement is truly significant." -SHELLEY LEE, author of Claiming the Oriental Cateway: Prewar Seattle and Japanese America

"This deeply researched and brilliantly argued history reveals how Asian and Indigenous workers built the Emerald City—and how their labors and legacies were all but erased in the name of so-called progress."-MATTHEW KLINGLE, author of Emerald City: An Environmental History of Seattle

EMIL AND KATHLEEN SICK BOOK SERIES IN WESTERN HISTORY AND BIOGRAPHY

\section{JULY}

250 pp., 1 color illus, 27 b\&w illus., 3 maps, $6 \times 9$ in. 


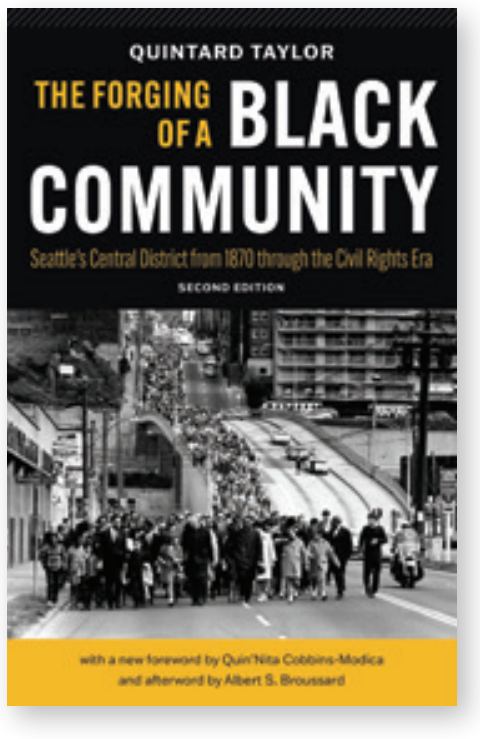

\section{The Forging of a Black Community}

\section{Seattle's Central District from 1870 through the Civil Rights Era} SECOND EDITION

Quintard Taylor

Forewords by Quin'Nita Cobbins-Modica and Norm Rice Afterword by Albert S. Broussard

\section{A CRITICALLY IMPORTANT CLASSIC ON SEATTLE HISTORY AND BLACK URBANIZATION}

PACIFIC NORTHWEST | HISTORY | AFRICAN AMERICAN STUDIES $\$ 99.00 x$ / £79.00 HC/ISBN 9780295750644 \$24.95S / £18.99 PB / ISBN 9780295750415 \$24.95s / f18.99 EB / ISBN 9780295750651
SEATTLE'S FIRST BLACK RESIDENT WAS A SAILOR NAMED MANuel Lopes who arrived in 1858 and became the small community's first barber. By the early twentieth century, black life in Seattle coalesced in the Central District, a four-square-mile section east of downtown. Black Seattle, however, was never a monolith. Through world wars, economic booms and busts, and the civil rights and black power movements of the 1960s, the African American community negotiated intragroup conflicts and used varied approaches to challenge racial inequity. Despite these differences, the community shared a distinct African American culture and black urban ethos. With a new foreword and afterword, this second edition of The Forging of a Black Community is essential to understanding the history and present of the largest black community in the Pacific Northwest.

Quintard Taylor is the Scott and Dorothy Bullitt Professor of American History and professor emeritus at the University of Washington. Quin'Nita Cobbins-Modica is assistant professor of history at Seattle Pacific University. Albert S. Broussard is Cornerstone Faculty Fellow and professor of history at Texas A\&M University. Norm Rice was Seattle's mayor from 1990 to 1997.

\begin{abstract}
"In this masterful and meticulously researched account spanning a century, Taylor weaves together a rich cultural legacy of a people, separated from the most populous black sections of the nation, who fashioned a vibrant community with scarce resources."-from the foreword by QUIN'NITA COBBINS-MODICA
\end{abstract}

"A powerful chronicle of the African American presence in Seattle over the last century."-from the foreword by NORM RICE

EMIL AND KATHLEEN SICK BOOK SERIES IN WESTERN HISTORY AND BIOGRAPHY

\section{MAY}

416 pp., 32 b\&w illus., 7 maps, 18 tables, $6 \times 9$ in. 

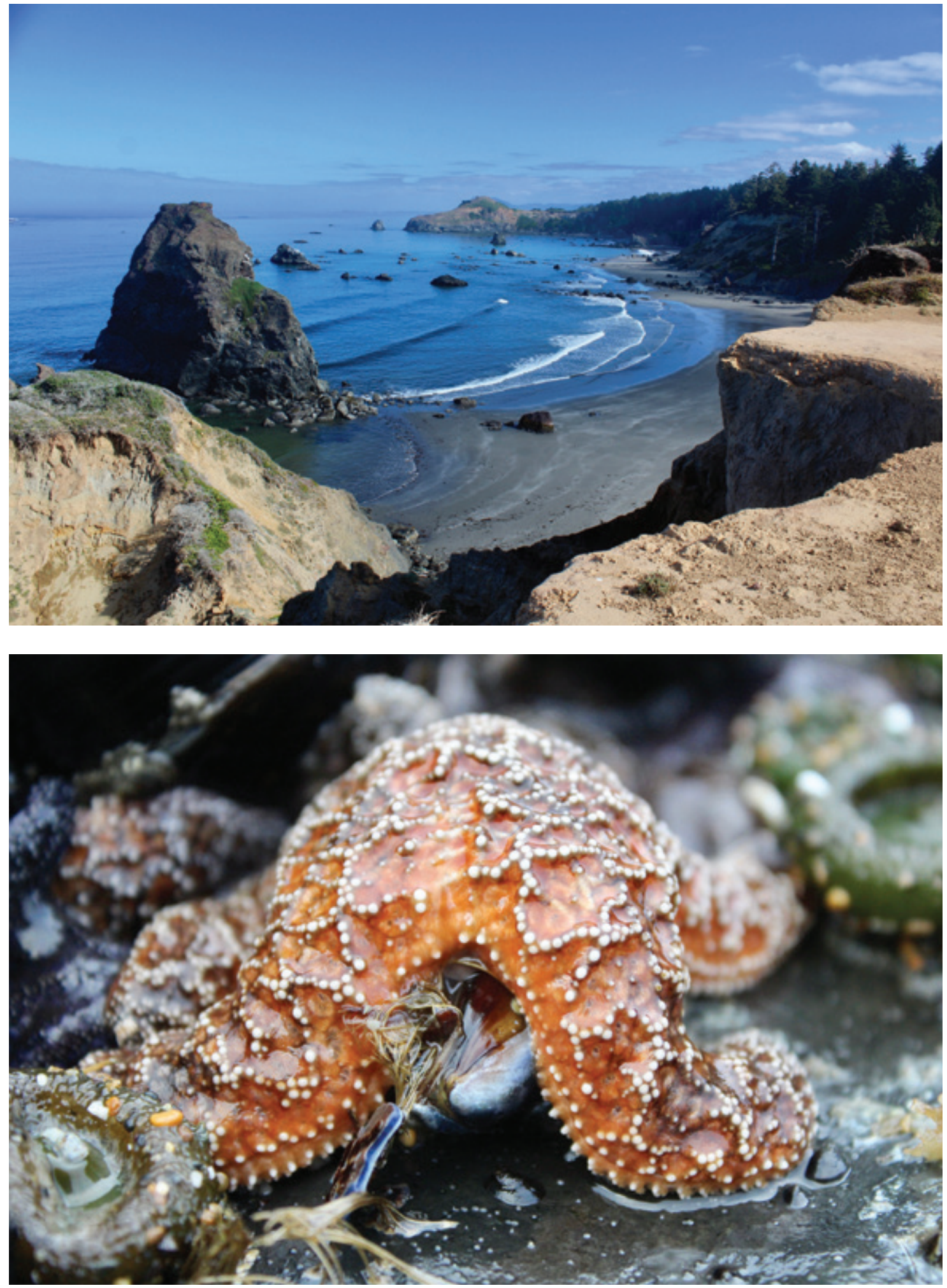


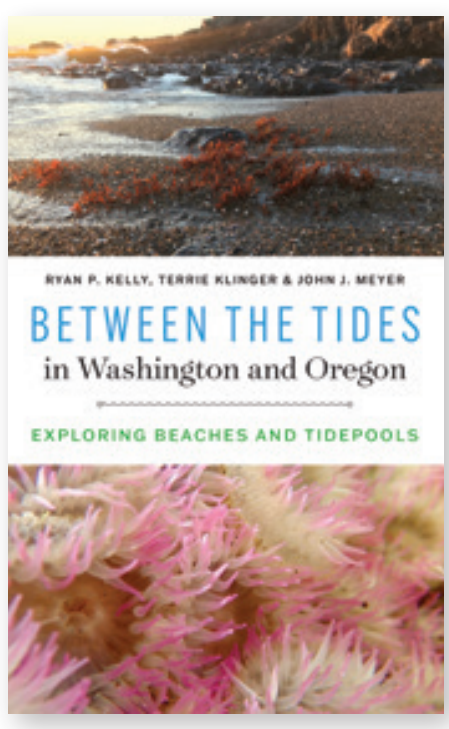

Between the Tides in Washington and Oregon

Exploring Beaches and Tidepools

Ryan P. Kelly, Terrie Klinger, and John J. Meyer

A FASCINATING GUIDE TO THE SECRET WORLDS OF THE INTERTIDAL ZONE

NATURE AND ENVIRONMENT | PACIFIC NORTHWEST

$\$ 24.95 /$ E18.99 PB / ISBN 9780295749969

$\$ 24.95$ / £18.99 EB / ISBN 9780295749976
BETWEEN THE EBB AND FLOW OF HIGH AND LOW TIDE EXIST some of the most vibrant ecosystems on Earth. A spectacular variety of life flourishes at the edge of the beach: anemones talk to each other through chemical signaling, clingfish grip rocks and resist the surging tide, and bioluminescent dinoflagellates-a kind of single-celled alga-light up disturbances in the shallow water like glowing fingerprints.

This guidebook helps readers uncover the hidden workings of the natural world of the shoreline. Richly illustrated and accessibly written, Between the Tides in Washington and Oregon illuminates the scientific forces that shape the diversity of life at each beach and tidepool-perfect for the curious beachgoer.

FEATURES INCLUDE:

- Profiles of popular and off-the-beaten-track sites to visit along the Greater Salish Sea, Puget Sound, and Washington and Oregon coasts

- Captivating stories of both common and less familiar species

- A lively introduction to how coastal ecosystems work and why no two beaches are ever alike

Ryan P. Kelly is associate professor in the University of Washington's School of Marine and Environmental Affairs. Terrie Klinger is professor in the University of Washington's School of Marine and Environmental Affairs. John J. Meyer is director of science communication in the University of Washington's College of the Environment.
"A fun and informative journey into the incredible biodiversity of the Pacific Northwest. This book will unlock curiosity in young and old alike!"-SALLY JEWELL, former US Secretary of the Interior

"This book will help you become a shoreline detective able to appreciate the joys of going to the beach. The tone is light, it's fun to read, and it'll make you want to climb out of your cozy reading chair and start exploring."-JOSEPH K. GAYDOS, VMD, PhD, coauthor of The Salish Sea: Jewel of the Pacific Northwest

A RUTH KIRK BOOK

A SAMUEL AND ALTHEA STROUM BOOK

JUNE

280 pp., 128 color illus., 5 maps, $5.5 \times 8.5$ in. 


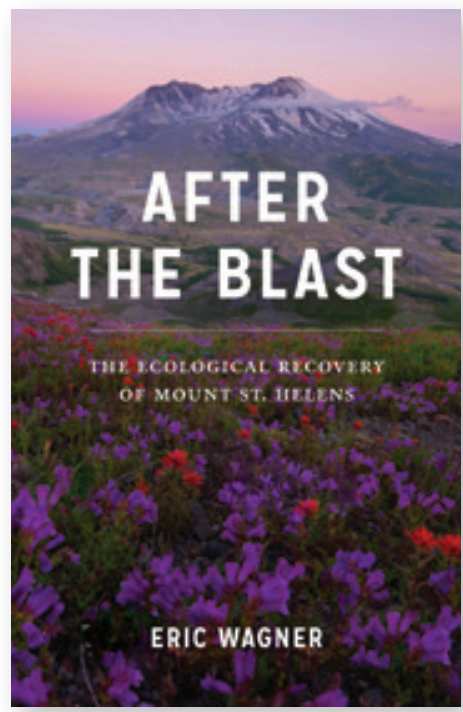

\section{After the Blast}

The Ecological Recovery of Mount St. Helens

\section{Eric Wagner}

SURVIVAL AND RETURN IN THE FACE OF

EXTRAORDINARY DESTRUCTION

PACIFIC NORTHWEST | NATURE AND ENVIRONMENT

$\$ 19.95$ / f14.99 PB / ISBN 9780295750712

ON MAY 18, 1980, PEOPLE ALL OVER THE WORLD WATCHED with awe and horror as Mount St. Helens erupted. Fifty-seven people were killed and hundreds of square miles of what had been lush forests and wild rivers were to all appearances destroyed.

Ecologists thought they would have to wait years, or even decades, for life to return to the mountain, but when forest scientist Jerry Franklin helicoptered into the blast area a couple of weeks after the eruption, he found small plants bursting through the ash and animals skittering over the ground. Stunned, he realized he and his colleagues had been thinking of the volcano in completely the wrong way. Rather than being a dead zone, the mountain was very much alive.

Mount St. Helens has been surprising ecologists ever since, and in After the Blast Eric Wagner takes readers on a fascinating journey through the blast area and beyond. From fireweed to elk, the plants and animals Franklin saw would not just change how ecologists approached the eruption and its landscape, but also prompt them to think in new ways about how life responds in the face of seemingly total devastation.

Eric Wagner, who earned a $\mathrm{PhD}$ in biology from the University of Washington, writes regularly about animals and the environment. He is author of Penguins in the Desert and coauthor of Once and Future River: Reclaiming the Duwamish. He climbs Mount St. Helens annually.
"A superb look at scientists and science at work."-Publishers Weekly

"A lively, enthusiastic look at the post-eruption landscape."

-The Oregonian

"Thoroughly reported and gracefully written-this account of scientists doing fascinating research on the ecology of Mount St. Helens is pretty much perfect."-STEVE OLSON, author of Eruption: The Untold Story of Mount St. Helens

\section{A RUTH KIRK BOOK}

\section{APRIL}

264 pp., 20 color illus., 2 b\&w illus., 1 map, $6 \times 9$ in. 


\section{SUSAN HOUGH}

The GREAT

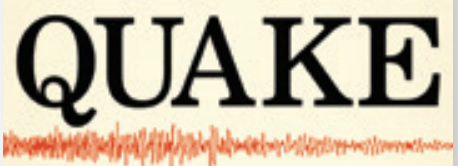

\section{DEBATE}

THE CRUSADER, THE SKEPTIC, AND THE RISE OF

MODERN SEISMOLOGY

\section{The Great Quake Debate}

The Crusader, the Skeptic, and the Rise of Modern Seismology

\section{Susan Hough}

THE STORY OF AN EPIC CLASH OVER CALIFORNIA'S

EARTHQUAKE FUTURE

NATURE AND ENVIRONMENT | SCIENCE AND TECHNOLOGY | US HISTORY

$\$ 19.95$ / f14.99 PB / ISBN 9780295750729
IN THE FIRST HALF OF THE TWENTIETH CENTURY, WHEN SEISmology was still in in its infancy, renowned geologist Bailey Willis faced off with fellow high-profile scientist Robert T. Hill in a debate with life-or-death consequences for the millions of people migrating west. Their conflict centered on a consequential question: Is Southern California earthquake country?

These entwined biographies of Hill and Willis offer a lively, accessible account of the ways that politics and financial interests influenced the development of earthquake science. During this period of debate, severe quakes in Santa Barbara (1925) and Long Beach (1933) caused scores of deaths and a significant amount of damage, offering turning points for scientific knowledge and mainstreaming the idea of earthquake safety.

The Great Quake Debate sheds light on enduring questions surrounding the environmental hazards of our dynamic planet. What challenges face scientists bearing bad news in the public arena? How do we balance risk and the need to sustain communities and cities? And how well has California come to grips with its many faults?

Susan Hough is a research seismologist in Pasadena, California. Her popular science books include Predicting the Unpredictable: The Tumultuous Science of Earthquake Prediction and Richter's Scale: Measure of an Earthquake, Measure of a Man. She is a past president of the Seismological Society of America and a Fellow of the American Geophysical Union.
"A delightful, timely glimpse into a little-known but fascinating debate among earthquake scientists regarding the seismic threat to Southern California."-ALEXANDRA WITZE, coauthor of Island on Fire: The Extraordinary Story of a Forgotten Volcano That Changed the World

"This book is historical and biographical writing at its very best."

-Environment and History

APRIL

328 pp., 18 b\&w illus., 3 maps, $6 \times 9$ in . 


\section{Charged Charged}

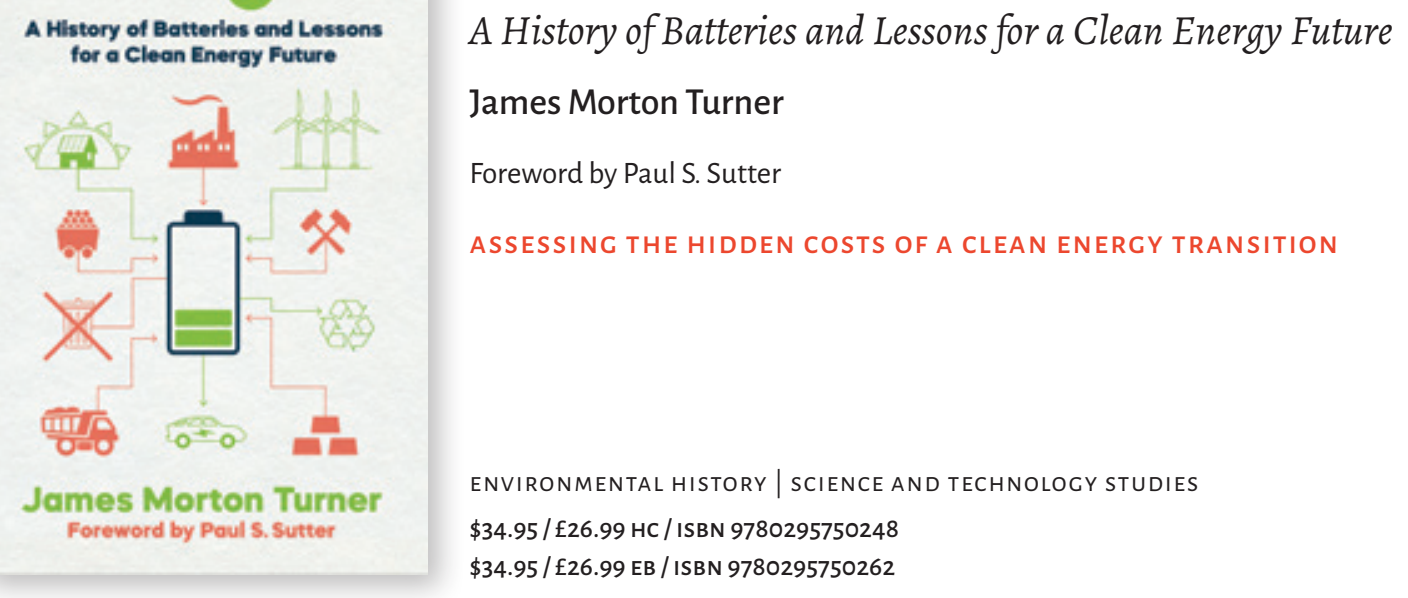

FOR A CLEAN ENERGY FUTURE, FEW TECHNOLOGIES ARE MORE important than batteries. Used for powering zero-emission vehicles, storing electricity from solar panels and wind turbines, and revitalizing the electric grid, batteries are essential to scaling up the renewable energy resources that help address global warming. But given the unique environmental impact of batteries-including mining, disposal, and more-does a clean energy transition risk trading one set of problems for another?

In Charged, James Morton Turner unpacks the history of batteries to explore why solving "the battery problem" is critical to a clean energy transition. At a time when climate activists focus on what a clean energy future will create-sustainability, resiliency, and climate justice-considering the history of batteries offers a sharp reminder of what building a clean energy future will consumelithium, graphite, nickel, and other specialized materials. With new insight on questions of justice and sustainability, Turner draws on the past for crucial lessons that will help us build a clean energy future, from the ground up.

James Morton Turner is professor of environmental studies at Wellesley College. He is author of The Promise of Wilderness: American Environmental Politics since 1964 and coauthor of The Republican Reversal: Conservatives and the Environment from Nixon to Trump.

"Turner's pathbreaking book deftly unpacks a key feature of modern history—the battery—and traces its globe-spanning material footprint. Detailing the incremental successes in battery engineering and recycling alongside the industry's persistent failures in social and environmental justice, Charged is nothing short of a manual for building a more humane clean energy future." -MEGAN A. BLACK, author of The Global Interior: Mineral Frontiers and American Power

WEYERHAEUSER ENVIRONMENTAL BOOKS
MAY

264 pp., 12 b\&w illus., 6 × 9 in. 


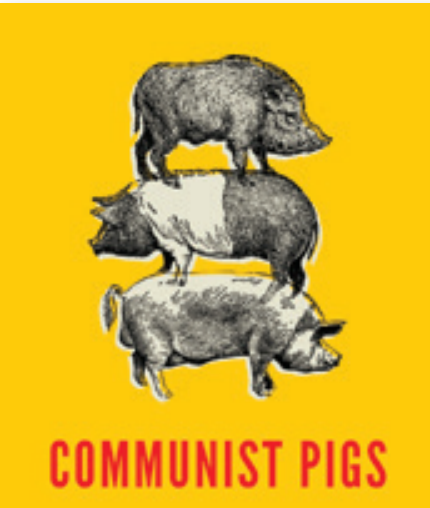

AN ANIMAL HISTORY OF EAST GERMANY'S RISE AND EALL

THOMAS FLEISCHMAK

\title{
Communist Pigs
}

\author{
An Animal History of East Germany's Rise and Fall \\ Thomas Fleischman \\ Foreword by Paul S. Sutter
}

WHAT INDUSTRIAL AGRICULTURE REVEALS ABOUT COMMUNISM-

AND CAPITALISM TOO

ENVIRONMENTAL HISTORY

$\$ 30.00$ / f22.99 PB / ISBN 9780295750699

THE PIG PLAYED A FUNDAMENTAL ROLE IN THE GERMAN DEMOcratic Republic's attempts to create and sustain a modern, industrial food system built on communist principles. By the mid-1980s, East Germany produced more pork per capita than West Germany and the UK, while also suffering the unintended consequences of manure pollution, animal disease, and rolling food shortages.

The pig is a highly adaptive animal, and Thomas Fleischman uncovers three types of pig that played roles in this history: the industrial pig, remade to suit the conditions of factory farming; the wild boar, whose overpopulation was a side effect of agricultural development and the garden pig, reflective of the regime's growing acceptance of private farming within the planned economy.

Fleischman chronicles East Germany's journey from family farms to factory farms, explaining how communist principles shaped the adoption of industrial agriculture practices. More broadly, he argues that agriculture under communism came to reflect the practices of capitalist agriculture, and that the pork industry clearly illustrates this convergence. His analysis sheds light on the causes of the country's environmental and political collapse in 1989 and offers a warning about the high cost of cheap food in the present and future.

Communist Pigs was a finalist for the Turku Book Award, European Society for Environmental History.

“Fleischman's enjoyable and intelligent study convincingly demonstrates how the pork industry was integral to the rise and fall of East German socialism."-Boston Review

"[A] fascinating and exhaustive study... An excellent storyteller, Fleischman has produced a very well-written book that will be useful to general readers and specialists alike."-Choice

WEYERHAEUSER ENVIRONMENTAL BOOKS

Thomas Fleischman is assistant professor of history at the University of Rochester. 


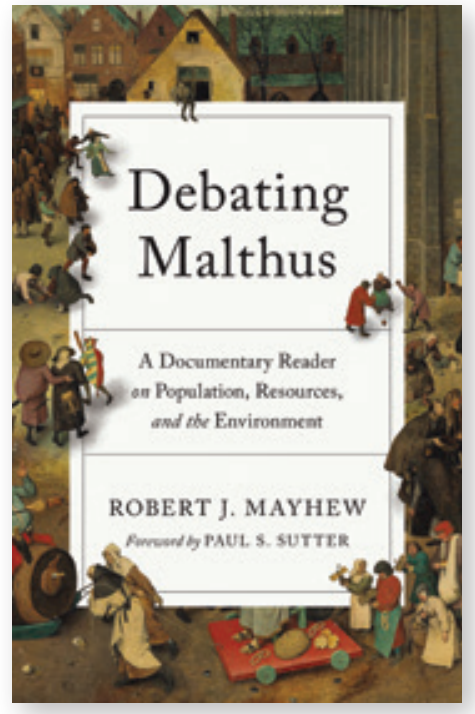

\title{
Debating Malthus
}

\author{
A Documentary Reader on Population, Resources, \\ and the Environment
}

Edited by Robert ]. Mayhew

Foreword by Paul S. Sutter

INTRODUCES READERS TO THE PLACE OF POPULATION IN

ENVIRONMENTAL THINKINC

ENVIRONMENTAL HISTORY

$\$ 99.00 x$ / £79.00 HC / ISBN 9780295749891

$\$ 30.00$ / E22.99 PB / ISBN 9780295749907

$\$ 30.00$ s / £22.99 EB / ISBN 9780295749914

FOR CENTURIES, THINKING ABOUT THE EARTH'S INCREASING

human population has been tied to environmental ideas and political action. This highly teachable collection of contextualized primary sources allows readers to follow European and North American discussions about intertwined and evolving concepts of population, resources, and the natural environment from early contexts in the sixteenth century right through to the present day.

Edited and introduced by Robert J. Mayhew, a noted biographer of Thomas Robert Malthus-whose Essay on the Principle of Population (1798), excerpted here, is an influential and controversial take on the topic-this volume explores such themes as evolution, eugenics, war, social justice, birth control, environmental Armageddon, and climate change. Other responses to the idea of new "population bombs" are represented here by radical feminist work, by Indigenous views of the population-environment nexus, and by intersectional approaches. By learning the patterns of this discourse, readers will be better able to critically evaluate historical conversations as well as contemporary debates.

Robert J. Mayhew is Senior Tutor at Pembroke College, Cambridge, and a Fellow of the British Academy. His many books include Malthus: The Life and Legacies of an Untimely Prophet.

"An erudite and stimulating work that addresses Malthus's neglected legacy within environmental history. Debating Malthus is the only sourcebook to provide a deeper historical approach with such a wide chronological scope."-FREDRIK ALBRITTON JONSSON, University of Chicago

"A much-needed intellectual map of the enduring complex of population and resources, and a clear journey over difficult terrain."

-ALISON BASHFORD, University of New South Wales

WEYERHAEUSER ENVIRONMENTAL CLASSICS
MARCH

256 pp., $6 \times 9$ in. 


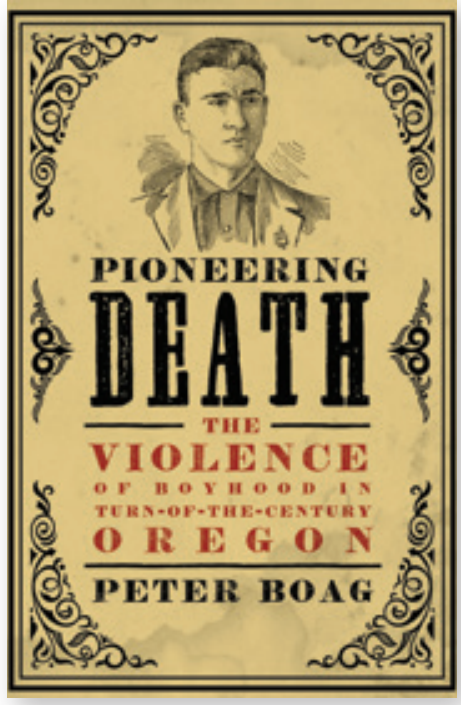

\title{
Pioneering Death
}

\author{
The Violence of Boyhood in Turn-of-the-Century Oregon \\ Peter Boag
}

A SHOCKING MURDER UNCOVERS THE BRUTAL REALITIES OF

FRONTIER LIFE

PACIFIC NORTHWEST HISTORY

$\$ 99.00 x$ / f79.00 HC / ISBN 9780295749983

$\$ 30.00$ / f22.99 PB / ISBN 9780295750637

$\$ 30.00$ / £22.99 EB / ISBN 9780295749990

ON AN AUTUMN DAY IN 1895 IN A SMALL OREGON FARMING community, eighteen-year-old Loyd Montgomery shot his parents and a neighbor in a gruesome act that reverberated up and down the West Coast. Contemporary responses ranged from discussion of the wayward youths of America and parental failings and responsibilities to the troubles of rural life. Historian Peter Boag suggests that Montgomery's slaying of his parents and his consequent hanging exposed the fault lines of a rapidly industrializing and urbanizing society.

In Pioneering Death, Boag examines how the Brownsville parricide sheds light on the destabilizing transitions within the rural United States at the end of the nineteenth century. While pioneer families celebrated and memorialized founders of western white settler society, their children faced a present and future in frightening decline. Connecting a fascinating true-crime story with the broader forces that produced the murders, Boag uncovers how Loyd's violent acts reflected the brutality of American colonizing efforts, the anxieties of global capitalism, and the buried traumas of childhood in the American West.

Peter Boag is professor and Columbia Chair in the History of the American West at Washington State University. He is author of Re-Dressing America's Frontier Past; Same-Sex Affairs: Constructing and Controlling Homosexuality in the Pacific Northwest; and Environment and Experience: Settlement Culture in Nineteenth-Century Oregon.

"With the bleak story of a triple murder, Boag explores the emotional landscape of society and family in the rural West at the end of the frontier era. The result is a stark portrait of the violence and stresses of growing up in one of America's more mythologized settings."-ELLIOTT WEST, author of Growing Up with the Country

"Boag uses a gripping local story to obliterate the fictions of the white 'pioneer' tale. This is narrative history-powerful, painful, and full of paradoxes-at its very best." -RYAN DEARINGER, author of The Filth of Progress

EMIL AND KATHLEEN SICK BOOK SERIES IN WESTERN HISTORY AND BIOGRAPHY

\section{APRIL}

312 pp., 25 b\&w illus., 6 maps, 1 chart, $6 \times 9$ in. 


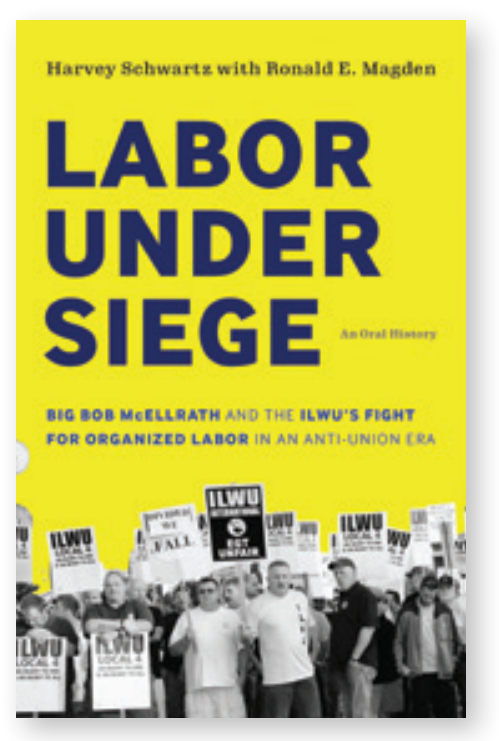

\section{Labor under Siege}

Big Bob McEllrath and the ILWU's Fight for Organized Labor in an Anti-Union Era

\author{
Harvey Schwartz with Ronald E. Magden
}

COMPELLING STORIES AND FORCEFUL VOICES CAPTURE A TENACIOUS

UNION IN TRANSITION

WESTERN HISTORY | LABOR | BIOCRAPHY

$\$ 99.00 \times$ / f79.00 HC / ISBN 9780295750323

$\$ 30.00$ s / £22.99 PB / ISBN 9780295750330

$\$ 30.00$ s / £22.99 EB / ISBN 9780295750347

AT SIX FEET FOUR AND WITH A POWERFUL SPEAKING STYLE, Big Bob-Robert McEllrath's waterfront handle—was heralded for his charisma, unifying vision, and negotiating prowess. President of the International Longshore and Warehouse Union (ILWU) for twelve eventful years, McEllrath retired in 2018 after nearly forty years as a union officer. More than a biography of a man with a storied career, Labor under Siege explores how the influential union persisted in an era when the US labor movement was under attack and seemingly in retreat.

In the face of grave dangers since the 1980s, including threats from corporations, government authorities, law enforcement agents, and even other labor unions, the ILWU has persevered and retained its vibrancy. Offering insight into Big Bob's leadership and a close-up view of how decision-making and policy were carried out to ensure the union's survival, Labor under Siege shows how union officers and rank-and-file members shaped ILWU strategy and furthered the union's legacy of advocating for workers' rights, democracy, and justice.

Harvey Schwartz is curator of the Oral History Collection for the ILWU Library in San Francisco and author of Building the Golden Gate Bridge: A Workers' Oral History and Solidarity Stories: An Oral History of the ILWU. Ronald E. Magden (1926-2018) is the author of several books, including A History of Seattle Waterfront Workers, 1884-1934 and two accounts of longshore unionism in Tacoma.

"A model of oral history. The ILWU is such a fascinating union with its militant past that bleeds into the present, making Labor under Siege all the more compelling."-ERIK LOOMIS, author of A History of America in Ten Strikes

"Robert McEllrath steered the legendary, militant West Coast dockworkers union through some of its most tumultuous waters. Schwartz, a consummate oral historian, lets the voices of 'Big' Bob and those around him describe those stormy seas."

-PETER COLE, author of Dockworker Power: Race and Activism in Durban and the San Francisco Bay Area

JULY

296 pp., 17 b\&w illus., 6 × 9 in. 


\section{Greg Hall Writing Iabor's Imancipation}

The Anarchist Life

and Times of Jay Fox

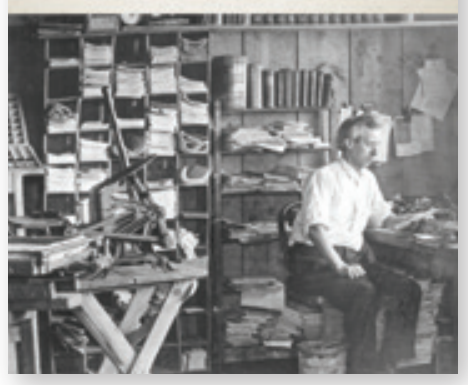

\section{Writing Labor's Emancipation}

\author{
The Anarchist Life and Times of Jay Fox
}

\section{Greg Hall}

PORTRAYS AN AGITATOR AND HIS EXTRAORDINARY TIMES

PACIFIC NORTHWEST HISTORY | BIOGRAPHY

\$99.00x / £79.00 HC / ISBN 9780295750576

$\$ 30.00$ / £22.99 PB / ISBN 9780295750583

$\$ 30.00$ S — £22.99 EB / ISBN 9780295750590

JAY FOX (1870-1961) WAS A JOURNALIST, INTELLECTUAL, AND labor militant, whose influence rippled across the country. In Writing Labor's Emancipation, historian Greg Hall traces Fox's unorthodox life to shed light on the shifting dynamics in US labor radicalism from the late nineteenth to the early twentieth century.

Radicalized as a teenager after witnessing the Haymarket tragedy, Fox embarked on a lifetime of labor organizing, helping build anarchist communities (including Home, Washington), and, perhaps most notably, working as a writer. Thanks to his accessible writing style, insightful working-class perspective, and sharp wit, he became a popular and influential voice, often in dialogue with fellow anarchists such as Emma Goldman and Lucy Parsons.

Drawing on previously unused sources, Hall both explores Fox's life and shines a light on the utopians, revolutionaries, and union men and women with whom Fox associated and debated. Hall's research ultimately provides valuable knowledge of the lived experiences of working-class Americans and brings to light alternative visions for activism and social change.

Greg Hall is professor of history at Western Illinois University. He is author of Harvest Wobblies: The Industrial Workers of the World and Agricultural Laborers in the American West, 1905-1930.

"Fox has not been given his appropriate due. This book about an activist willing to change with the times is exactly what was missing from the historical record."-CANDACE FALK, author of Love, Anarchy, and Emma Goldman and editor/director of the Emma Goldman Papers

"Superb... Hall's study of Fox contributes a great deal by tracing the working-class rootedness of anarchism and the importance of anarchism in the history of American labor."-AARON GOINGS, author of The Port of Missing Men: Billy Cohl, Labor, and Brutal Times in the Pacific Northwest

A SAMUEL AND ALTHEA STROUM BOOK

\section{AUGUST}

288 pp., 10 b\&w illus., $6 \times 9$ in. 


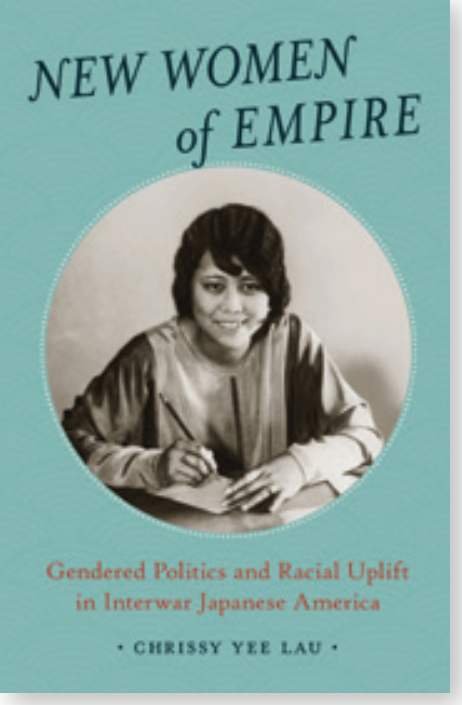

\title{
New Women of Empire
}

\author{
Gendered Politics and Racial Uplift in Interwar \\ Japanese America
}

\author{
Chrissy Yee Lau
}

CHRONICLES THE RISE OF A NEW GENERATION WHO TRANSFORMED

WHAT IT MEANT TO BE JAPANESE AMERICAN

ASIAN AMERICAN STUDIES | US HISTORY | WOMEN'S, GENDER, AND SEXUALITY STUDIES $\$ 99.00 \times$ / £79.00 HC / ISBN 9780295750514 $\$ 30.00$ / f22.99 PB / ISBN 9780295750521 $\$ 30.00$ S / f22.99 EB / ISBN 9780295750538

STRONG, BOLD, AND VIVACIOUS-JAPANESE AMERICAN YOUNG women were leaders and heroines of the Roaring Twenties. Controversial to the male immigrant elite for their rebellion against gender norms, these women made indelible changes in the community, including expanding sexual freedoms, redefining women's roles in public and private spheres, and furthering racial justice work. Young men also reconceptualized their ideas of manliness to focus on intellectualism and athleticism, as racist laws precluded many from expressing masculinity through land ownership or citizenry.

New Women of Empire centers the compelling life histories of five young women and men in Los Angeles to illuminate how they negotiated overlapping imperialisms through new gender roles. With extensive youth networks and the largest Japanese population in the United States, Los Angeles was a critical site of transnational relations, and in the 1920s and '30s Japanese American youth became politicized through active participation in Christian civic organizations.

Through youth clubs, athletics, and cultural ambassadorship, these young leaders reshaped Japanese and US imperialisms and provided the groundwork for future expressions of model minority respectability and Japanese American feminisms.

Chrissy Yee Lau is assistant professor of history at California State University, Monterey Bay.

"This well-researched, highly accessible study... illuminates how Christian Nisei formed gendered, transpacific identities and attachments and how Nisei 'New Women' laid a clear path toward both the 'model minority' myth and Asian American feminism."

-NAOKO WAKE, author of American

Survivors: Trans-Pacific Memories of Hiroshima and Nagasaki

"Showcases key turning points and strategies for Japanese American self-respect and uplift. Their fascinating stories bring the book's focus on gendered politics and transpacific womanhood to life."-SHIHO IMAI, author of Creating the Nisei Market

A CAPELL FAMILY BOOK

JUNE

200 pp., 13 b\&w illus., $6 \times 9$ in. 


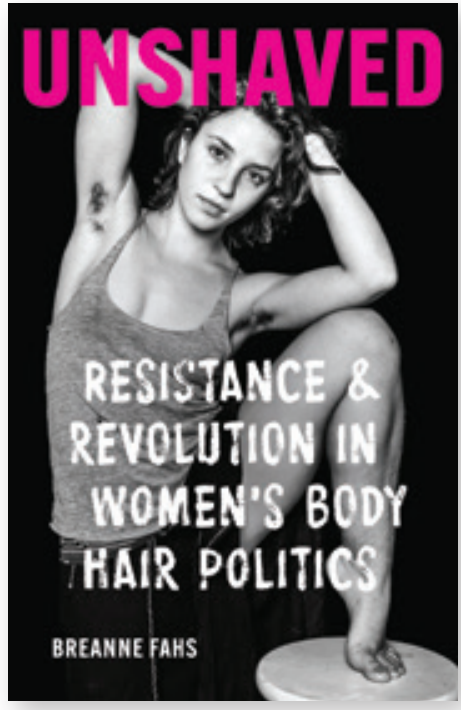

\section{Unshaved}

\section{Resistance and Revolution in Women's Body Hair Politics \\ Breanne Fahs}

GROSS. DIRTY. MONSTROUS. MANLY. BEAUTIFUL.

NATURAL. POWERFUL.

WOMEN'S, GENDER, AND SEXUALITY STUDIES

$\$ 99.00 x /$ f79.00 HC / ISBN 9780295750279

$\$ 30.00$ / f22.99 PB / ISBN 9780295750286

$\$ 30.00$ / f22.99 EB / ISBN 9780295750293

BODY HAIR, ESPECIALLY ON WOMEN, PROVOKES, DISRUPTS, and, at times, offends. It is tangled up with culture itself-in art, families, workplaces, relationships, sex, the beauty industry, governments, and capitalism. From Chinese activists challenging the Communist Party, to students in Arizona rejecting their family and workplace ideas about grooming, to high-art feminist photographers boldly featuring hairy women, Fahs deftly explores the volatile and ever-changing landscape of women's body hair politics. She showcases an underground movement of artists, zine-makers, rebels, and activists who have used women's visible body hair as a declaration of freedom from patriarchal norms.

Fahs presents body hair not just as a personal grooming choice but as a connection to broader cultural stories about women's reproductive rights, feminist battlegrounds about autonomy, neoliberal intrusions into beauty regimens, and even global tensions around women's place in society. Ultimately, Unshaved shows the collision between the mundane and the extraordinary, the everyday and the revolutionary.

Breanne Fahs is professor of women and gender studies at Arizona State University. She is the editor of Burn It Down!: Feminist Manifestos for the Revolution and author of Firebrand Feminism; Out for Blood: Essays on Menstruation and Resistance; Women, Sex, and Madness: Notes from the Edge, and several other works.

"Fahs's lively writing, coupled with an abundance of evidence, convincingly illustrates how body hair is a path to difficult discussions regarding gender, bodies, power, and social control."-SAMANTHA KWAN, coauthor of Under the Knife: Cosmetic Surgery, Boundary Work, and the Pursuit of the Natural Fake

MAY

296 pp., 15 b\&w illus., 6 × 9 in. 


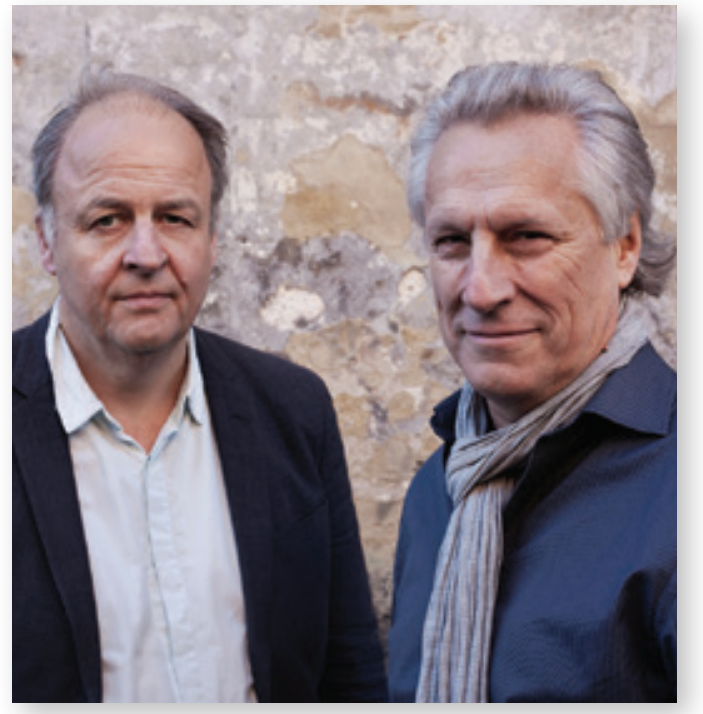

\title{
The Swedish Theory of Love
}

\author{
Individualism and Social Trust in Modern Sweden
}

\section{Henrik Berggren and Lars Trägårdh}

Translated by Stephen Donovan

EXPLORES THE PRODUCTIVE TENSION BETWEEN

INDIVIDUAL AUTONOMY AND SOCIAL WELFARE IN CONTEMPORARY SWEDEN

SCANDINAVIAN STUDIES

$\$ 99.00 \times$ / £79.00 HC / ISBN 9780295750545

$\$ 30.00$ / f22.99 PB / ISBN 9780295750552

$\$ 30.00$ / f22.99 EB / ISBN 9780295750569

IN 2020 SWEDEN'S RESPONSE TO COVID-19 DREW RENEWED attention to the Nordic nation in a way that pinpointed a seeming paradox. Long celebrated for its commitment to social solidarity, Sweden suddenly emerged as the last country in the West to resist lockdown while defending individual rights and responsibilities. To explain these contradictions, Henrik Berggren and Lars Trägårdh argue that the long-standing view of Sweden's welfare state as the result of socialist collectivism is flawed. While social values have been and remain strong, they have coexisted with a radical form of individualism.

The English edition of the Swedish bestseller Är svensken människa?, The Swedish Theory of Love examines a political culture that stresses individual autonomy on the one hand and trust in the state on the other. Delving into Swedish philosophy, cultural studies, sociology, literary criticism, and political science, the book moves beyond the perspective of rational social engineering to uncover the moral logic behind Sweden's welfare state: the notion that human relationships based on dependency and subordination lead to inauthenticity and that equality and autonomy are preconditions for genuine love and affection.

Henrik Berggren is a Swedish journalist and historian. Lars Trägårdh is a Swedish historian and public intellectual.

"With a remarkably wide range of sources and richness of argumentation, The Swedish Theory of Love explains the success of "the Swedish model" and its apparent paradox: that Swedes value individualism extremely highly but also exhibit a high degree of dependency on the state."-LYNN WILKINSON, University of Texas at Austin

"The long-awaited English translation of a classic Swedish text, The Swedish Theory of Love provides a nuanced and complex view of a topic often flattened and distorted."

-MARK SANDBERG, University of California, Berkeley

NEW DIRECTIONS IN SCANDINAVIAN STUDIES

JUNE

392 pp., 19 b\&w illus., 6 × 9 in. 


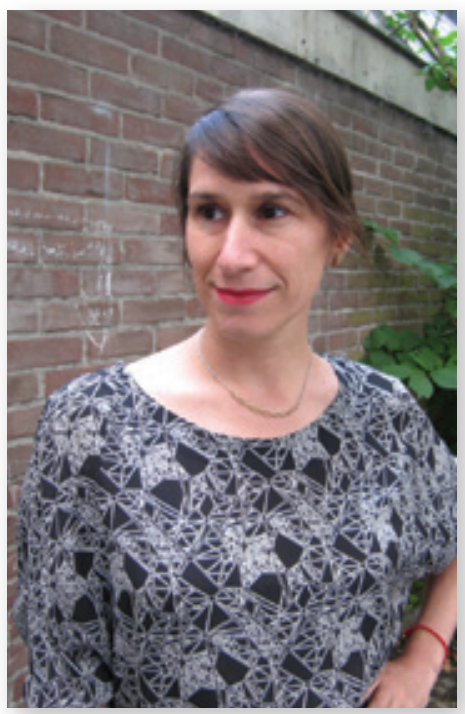

\section{Fixing the Image}

Ultrasound and the Visuality of Care in Phnom Penh

Jenna Grant

TRACES AFFECTIVE AND AESTHETIC DIMENSIONS OF MEDICAL

IMAGING TECHNOLOGIES

ANTHROPOLOGY | SOUTHEAST ASIAN STUDIES | WOMEN'S, GENDER, AND SEXUALITY STUDIES | SCIENCE AND TECHNOLOCY STUDIES

$\$ 99.00 \times$ / f79.00 HC / ISBN 9780295750606

$\$ 30.00$ / f22.99 PB / ISBN 9780295750613

$\$ 30.00$ S f £22.99 EB / ISBN 9780295750620

INTRODUCED IN PHNOM PENH AROUND 1990, AT THE TWI-

light of socialism and after two decades of conflict and upheaval, ultrasound took root in humanitarian and then privatized medicine. Services have since multiplied, promising diagnostic information and better prenatal and general health care. In Fixing the Image Jenna Grant draws on years of ethnographic and archival research to theorize the force and appeal of medical imaging in the urban landscape of Phnom Penh. Set within long genealogies of technology as tool of postcolonial modernity, and vision as central to skilled diagnosis in medicine and Theravada Buddhism, ultrasound offers stabilizing knowledge and elicits desire and pleasure, particularly for pregnant women. Grant offers the concept of "fixing"-which invokes repair, stabilization, and a dose of something to which one is addicted-to illuminate how ultrasound is entangled with practices of care and neglect across different domains. Fixing the Image thus provides a method for studying technological practice in terms of specific materialities and capacities of technologies-in this case, image production and the permeability of the body-illuminating how images are a material form of engagement between patients, between patients and their doctors, and between patients and their bodies.

Jenna Grant is assistant professor of anthropology at the University of Washington.

"This nuanced study reveals how ultrasound technology is embedded in-and productive of-dense social worlds in Phnom Penh. Grant's profound engagement with distinctively Cambodian idioms of knowledge and aesthetics make this a remarkable book."-KAREN STRASSLER, author of Demanding Images

"Enriches our understanding of medical technologies in the Global South, visualization theory in medical imaging, and the ethnography of technological adoption while providing a powerful alternative narrative of modern Cambodian history." - SOKHIENC AU, author of Mixed Medicines

\section{A MCLELLAN BOOK}

JULY

224 pp., 19 b\&w illus., 6 × 9 in. 

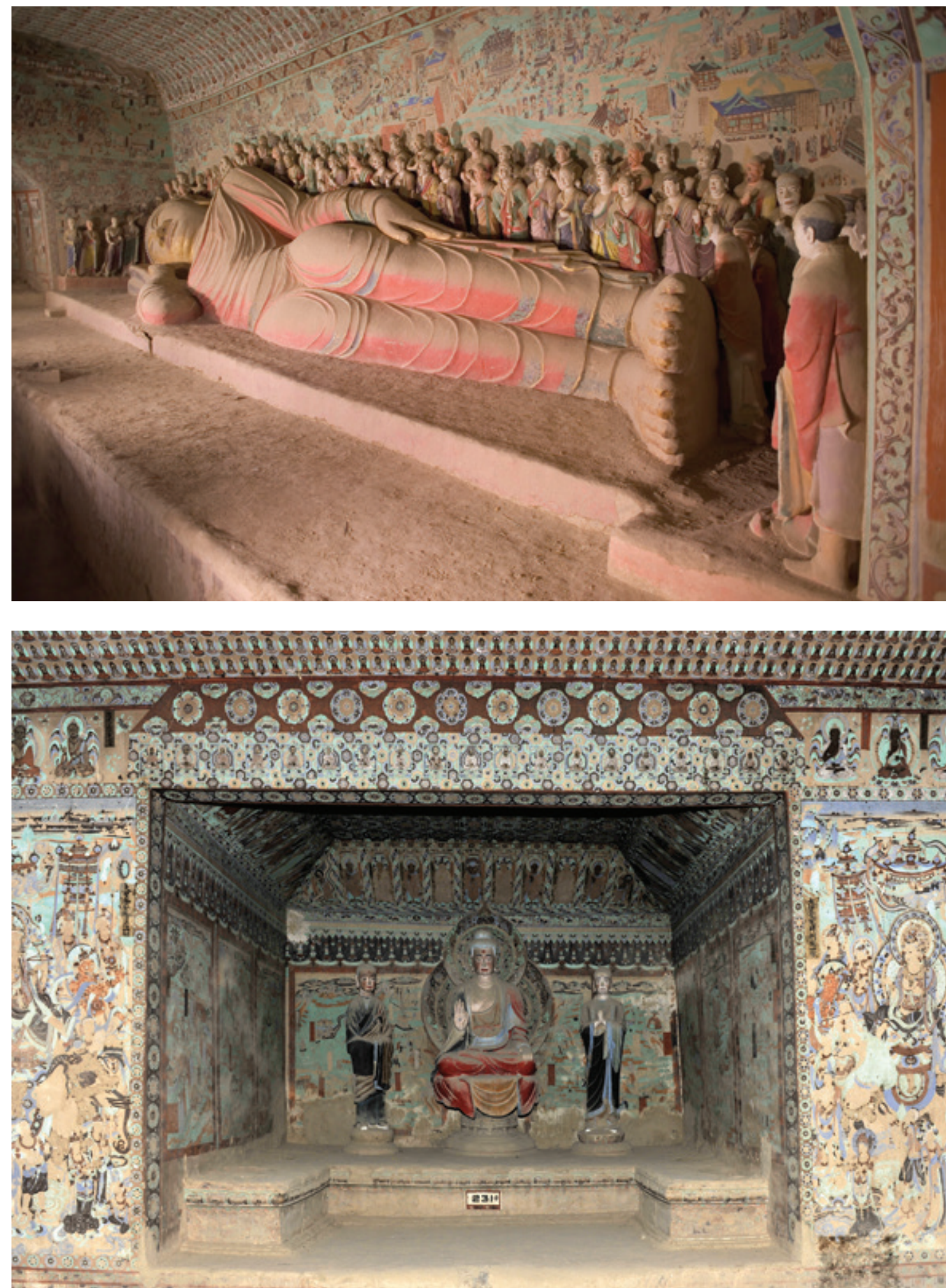


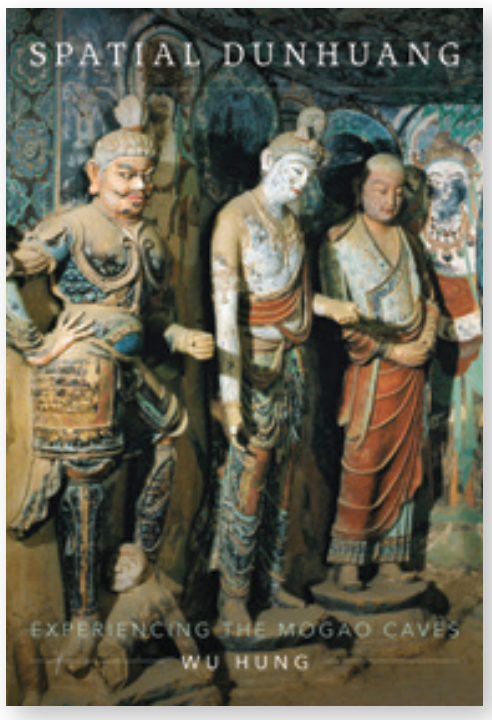

\section{Spatial Dunhuang}

\author{
Experiencing the Mogao Caves
}

\section{Wu Hung}

A PATH-BREAKING NEW STUDY OF A CELEBRATED SITE

OF BUDDHIST ART

ASIAN ART HISTORY | CHINA

$\$ 65.00$ / £52.00 HC/ISBN 9780295750200

$\$ 65.00$ / f52.00 EB / ISBN 9780295750217

\section{CONSTRUCTED OVER A MILLENNIUM FROM THE FOURTH TO}

fourteenth centuries CE near Dunhuang, an ancient border town along the Silk Road in northwest China, the Mogao Caves comprise the largest, most continuously created, and best-preserved treasure trove of Buddhist art in the world. Previous overviews of the art of Dunhuang have traced the caves' unilinear history. This book examines the caves from the perspective of space, treating them as physical and historical sites that can be approached, entered, and understood sensually. It prioritizes the actual experiences of the people of the past who built and used the caves.

Five spatial contexts provide rich material for analysis: Dunhuang as a multicultural historic place, the Mogao Cave complex as an evolving entity, the interior space of caves, interaction of the visual program with architectural space, and pictorial space within wall paintings that draws viewers into an otherworldly time. With its novel approach to this repository of religious art, Spatial Dunhuang will be a must-read for anyone interested in Buddhist art and for visitors to Dunhuang.

Wu Hung is Harrie A. Vanderstappen Distinguished Service Professor in Chinese Art History at the University of Chicago. He is the author of fifteen books and anthologies, including Story of Ruins: Presence and Absence in Chinese Art and Visual Culture and Contemporary Chinese Art: A History.

\begin{abstract}
"A highly original and refreshing work, this book is going to be a go-to volume for readers curious about the Mogao Caves as a local community effort."-EUGENE WANG, author of Shaping the Lotus Sutra: Buddhist Visual Culture in Medieval China
\end{abstract}

"A major concern of contemporary scholars is the lack of a book that can tell an interesting story about the history of the art of Mogao....Wu Hung writes one that is easy to read and at the same time offers an intellectual framework to approach the subject at both macro and micro levels."-HSUEH-MAN SHEN, author of Authentic Replicas: Buddhist Art in Medieval China

\section{A JOSEPH AND LAUREN ALLEN BOOK}

\section{AUGUST}

381 pp., 188 color illus., 1 map, 2 tables, $7 \times 10$ in. 


\section{THE Many Lives OF THE First Emperor of China}

ANTHONY J. BARBIERL-LOW

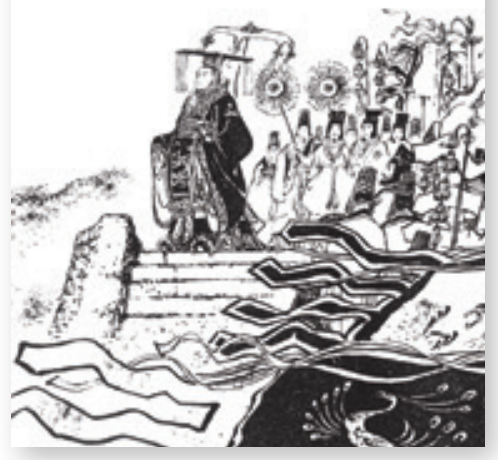

The Many Lives of the First Emperor of China

\author{
Anthony ]. Barbieri-Low \\ TYRANT OR NATIONAL HERO? AN INTERDISCIPLINARY \\ EXPLORATION OF CHINA'S FIRST EMPEROR
}

ASIAN STUDIES | CHINA

$\$ 65.00$ S / £52.00 HC/ ISBN 9780295750224

$\$ 65.00$ / f52.00 EB / ISBN 9780295750231

YING ZHENG, FOUNDER OF THE QIN EMPIRE, IS RECOGNIZED as a pivotal figure in world history, alongside other notable conquerors such as Alexander the Great, Genghis Khan, and Julius Caesar. His accomplishments include conquest of the warring states of ancient China, creation of an imperial system that endured for two millennia, and unification of Chinese culture through the promotion of a single writing system.

Only one biased historical account, written a century after his death, narrates his biography. Recently, however, archaeologists have revealed the lavish pits associated with his tomb and documents that demonstrate how his dynasty functioned. Debates about the First Emperor have raged since shortly after his demise, making him an ideological slate upon which politicians, revolutionaries, poets, painters, archaeologists, and movie directors have written their own biases, fears, and fantasies.

This book is neither a standard biography nor a dynastic history. Rather, it looks historically at interpretations of the First Emperor in history, literature, archaeology, and popular culture as a way to understand the interpreters as much as the subject of their interpretation.

Anthony J. Barbieri-Low is professor of Chinese history at the University of California, Santa Barbara. He is the author of Artisans in Early Imperial China and Ancient Egypt and Early China: State, Society, and Culture.

\author{
“Relatively few [scholars of early \\ history] have sought to consider \\ their topics in light of later times and \\ modern historiography. Rarer still \\ are those who incorporate modern \\ cultural phenomena such as film \\ and video games into their research. \\ These things are Barbieri-Low's great \\ contribution."-CHARLES SANFT, \\ University of Tennessee, Knoxville \\ "Makes scholarship on remote \\ ancient history relevant to our \\ contemporary globalized world. \\ The scope of this book is broad \\ across space, time, and academic \\ disciplines."-GUOLONG LAI, \\ University of Florida \\ A TRADITIONAL CHINESE \\ CULTURE AND SOCIETY BOOK

\section{JUNE} \\ 376 pp., 18 color illus., 48 b\&w illus., \\ $7 \times 10$ in.
}




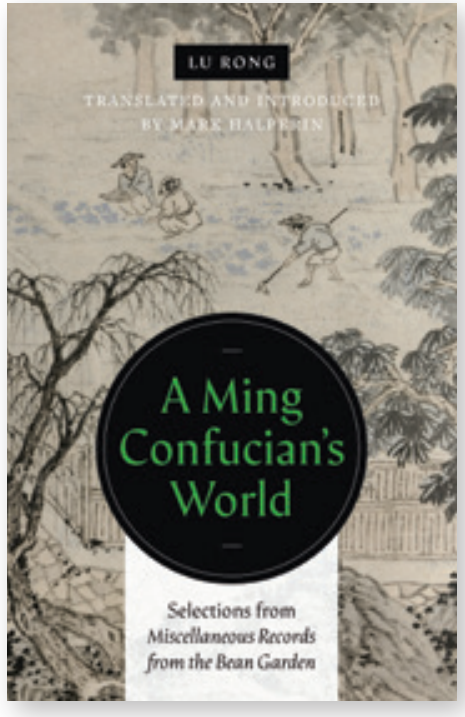

\section{A Ming Confucian's World}

\author{
Selections from Miscellaneous Records from
} the Bean Garden

\section{Lu Rong}

Translated and introduced by Mark Halperin

DAILY LIFE IN FIFTEENTH-CENTURY CHINA IN RICH DETAIL, FROM THE CITY TO THE COUNTRY, PALACE, AND FRONTIER

ASIAN STUDIES | CHINA | BIOGRAPHY $\$ 99.00 \times$ / f79.00 HC / ISBN 9780295749921 $\$ 30.00$ / £22.99 PB / ISBN 9780295749938 OA EDITION / DOI 10.6069/9780295749945

A FORGOTTEN CENTURY MARKS THE YEARS BETWEEN THE

Ming dynasty's (1368-1644) turbulent founding and its sixteenthcentury age of exploration and economic transformation. In this period of social stability, retired scholar-official Lu Rong chronicled his observations of Chinese society in Miscellaneous Records from the Bean Garden (Shuyuan zaji). Openly expressing his admirations and frustrations, Lu provides a window into the quotidian that sets Bean Garden apart from other works of the biji genre of "informal notes."

Mark Halperin organizes a translated selection of Lu's accounts from Miscellaneous Records from the Bean Garden to create a panorama of Ming life. A man of unusual curiosity, Lu describes multiple social classes, ethnicities, and locales in his accounts of political intrigues, farming techniques, religious practices, etiquette, crime, and family life. Centuries after their composition, Lu's words continue to provide a richly textured portrait of China on the cusp of the early modern era.

Lu Rong (1436-1494), a native of Suzhou Prefecture, spent his career in positions at the capital, the northern frontier, and south China. Mark Halperin is associate professor of East Asian languages and cultures at the University of California, Davis. He is author of Out of the Cloister: Literati Perspectives on Buddhism in Sung China, 960-1279.
"This first English translation of a major Ming biji presents fascinating material and vivid details about every aspect of Ming China." - CONG ELLEN ZHANG, University of Virginia

"Reveals glimpses of fifteenthcentury China that are not found in more orthodox histories. This is a necessary contribution to the growing corpus of informal Chinese literature available in English translation."

一JAMES M. HARGETT, SUNY Albany

A TRADITIONAL CHINESE CULTURE AND SOCIETY BOOK 


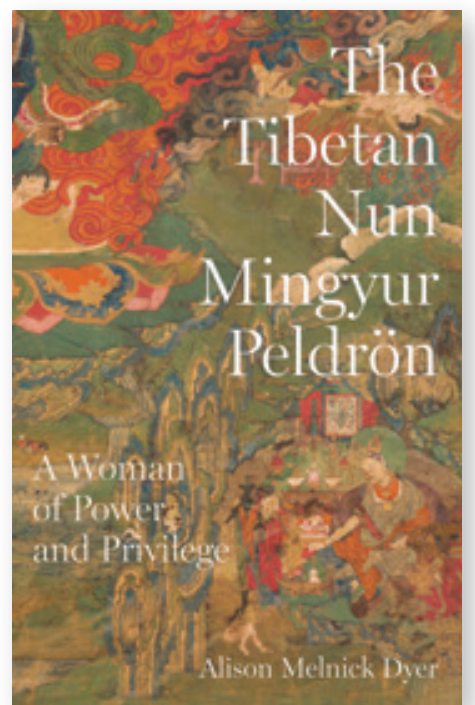

\title{
The Tibetan Nun Mingyur Peldrön
}

\author{
A Woman of Power and Privilege \\ Alison Melnick Dyer \\ THE AMAZING LIFE OF A HISTORICAL WOMAN WHO EMBODIED \\ BUDDHIST DIVINITY
}

ASIAN STUDIES | BIOGRAPHY | WOMEN'S, GENDER, AND SEXUALITY STUDIES

$\$ 99.00 x /$ £ $79.00 \mathrm{HC} /$ ISBN 9780295750354

$\$ 30.00$ S / £22.99 PB / ISBN 9780295750361

OA EDITION / DOI 10.6069/9780295750378

BORN TO A POWERFUL FAMILY AND EDUCATED AT THE PROMInent Mindröling Monastery, the Tibetan Buddhist nun and teacher Mingyur Peldrön (1699-1769) leveraged her privileged status and overcame significant adversity, including exile during a civil war, to play a central role in the reconstruction of her religious community. Alison Melnick Dyer employs literary and historical analysis, centered on a biography written by the nun's disciple Gyurmé Ösel, to consider how privilege influences individual authority, how authoritative Buddhist women have negotiated their position in gendered contexts, and how the lives of historical Buddhist women are (and are not) memorialized by their communities. Mingyur Peldrön's story challenges the dominant paradigms of women in religious life and adds nuance to our ideas about the history of gendered engagement in religious institutions. Her example serves as a means for better understanding of how gender can be both masked and asserted in the search for authority-operations that have wider implications for religious and political developments in eighteenth-century Tibet. In its engagement with Tibetan history, this study also illuminates the relationships between the Geluk and Nyingma schools of Tibetan Buddhism from the eighteenth century to the nonsectarian developments of the nineteenth century.

Alison Melnick Dyer is assistant professor of religious studies at Bates College.

"The issue of women's ordination status continues to be central in discussions of gender equity in Buddhism around the world today, and this book provides essential clues that will be of keen interest to scholars and practitioners alike." - KARMA LEKSHE TSOMO, author of Women in Buddhist Traditions

JULY

300 pp., $6 \times 9$ in. 


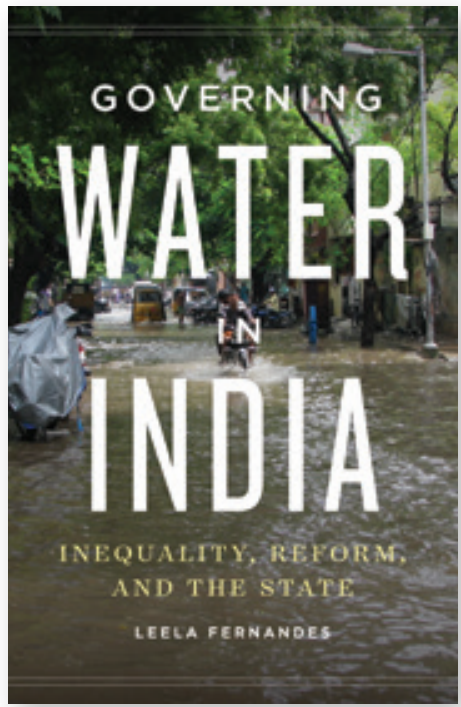

\title{
Governing Water in India
}

\author{
Inequality, Reform, and the State \\ Leela Fernandes \\ THE CHALLENGES OF MANAGING RESOURCE USE IN THE WORLD'S \\ LARGEST DEMOCRACY
}

ASIAN STUDIES: SOUTH ASIA | POLITICS | ENVIRONMENTAL STUDIES

$\$ 99.00 x /$ f79.00 HC / ISBN 9780295750422

$\$ 30.00$ S / £22.99 PB / ISBN 9780295750439

OA EDITION / DOI 10.6069/9780295750446

INTENSIFYING DROUGHTS AND COMPETING PRESSURES ON water resources foreground water scarcity as an urgent concern of the global climate change crisis. In India, individual, industrial, and agricultural water demands exacerbate inequities of access and expose the failures of state governance to regulate use. State policies and institutions influenced by global models of reform produce and magnify socio-economic injustice in this "water bureaucracy."

Drawing on historical records, an analysis of post-liberalization developments, and fieldwork in Chennai, Leela Fernandes traces the configuration of colonial historical legacies, developmental-state policies, and economic reforms that strain water resources and intensify inequality. While reforms of water governance promote privatization and decentralization, they strengthen the state's centralized control over water through city-based development models. Understanding the political economy of water thus illuminates the consequent failures of the state within countries of the Global South.

Leela Fernandes is the director and Stanley D. Golub Endowed Chair of the Henry M. Jackson School of International Studies at the University of Washington. She is author of India's New Middle Class and Transnational Feminism in the United States: Knowledge, Ethics, Power.

"Brilliantly argues how centralization tendencies occur in the liberal economy of India at both the national and sub-national levels."

-NAGESH PRABHU, author of Reflective Shadows: Political Economy of World Bank Lending to India

"Offers a rich description of the dynamics of state authority and a new space to understand centralization beyond the nature of Indian federalism."-VANDANA ASTHANA, author of Water Policy Processes in India: Discourses of Power and Resistance

JACKSON SCHOOL PUBLICATIONS IN INTERNATIONAL STUDIES

\section{AUCUST}

288 pp., 2 b\&w illus., 6 maps, 1 chart, 4 tables, $6 \times 9$ in.

WORLD, EXCEPT SOUTH ASIA 


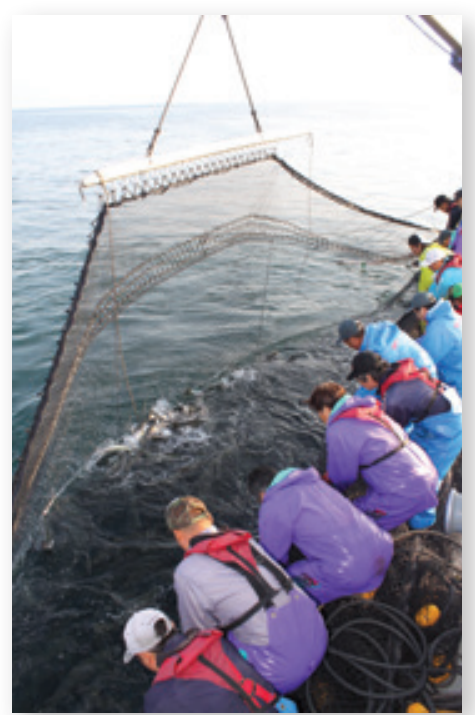

\section{Spawning Modern Fish}

Transnational Comparison in the Making of Japanese Salmon

Heather Anne Swanson

Foreword by K. Sivaramakrishnan

MULTISPECIES ETHNOGRAPHY TURNS ITS ATTENTION

TO THE BODIES OF FISH

ANTHROPOLOCY | ENVIRONMENTAL STUDIES | ASIAN STUDIES: JAPAN

$\$ 99.00 x$ / £79.00 HC / ISBN 9780295750385

$\$ 30.00$ S / £22.99 PB / ISBN 9780295750392

EBOOK EDITION / ISBN 9780295750408

SINCE THE MID-NINETEENTH CENTURY, AGRICULTURAL DEVEL-

opment and fisheries management in northern Japan have been profoundly shaped by how people within and beyond Japan have compared Hokkaido's landscapes to those of other places, as part of efforts to make the new Japanese nation-state more legibly "modern." In doing so, they engaged in heterodox modes of analogic thinking that reached out to diverse places, including the American West and southern Chile. Today, the comparisons made by Hokkaido fishing industry professionals, scientists, and Ainu indigenous groups between the island's forests, fields, and waters and those of others around the world continue to dramatically affect the region's approaches to environmental management and its physical landscapes. In this far-ranging ethnography, Heather Swanson shows how this traffic shapes the course of Hokkaido's development, its fish, and the lives of people on and beyond the island. Resulting encounters restructure not only trade dynamics and political economy but also multispecies relations in watersheds around the globe.

Heather Anne Swanson is associate professor of anthropology at Aarhus University, Denmark, and director of the Aarhus University Centre for the Environmental Humanities. She is the coeditor of Domestication Gone Wild: Politics and Practices of Multispecies Relations and Arts of Living on a Damaged Planet.
"Spans long-standing disciplinary interests in nations and nationmaking with emerging concerns in multispecies entanglements."

-C. ANNE CLAUS, American

University

"Simply put, it is the best book using the theory and methods of multispecies ethnography that I have read in years."-EBEN KIRKSEY, Deakin University

"Swanson suggests that comparison is a powerful world-making practice-molding identities, politics, national imaginaries, and structures of discourse.... A marvelous book." 一michael hathaway, Simon Fraser University

CULTURE, PLACE, AND NATURE

\section{AUGUST}

272 pp., 9 b\&w illus., 2 maps, 6 × 9 in. 


\section{CULTURE, PLACE, AND NATURE}

\section{K. Sivaramakrishnan, series editor}

Centered in anthropology, the Culture, Place, and Nature series encompasses new interdisciplinary social science research on environmental issues, focusing on the intersection of culture, ecology, and politics in global, national, and local contexts. Contributors to the series view environmental knowledge and issues from the multiple and often conflicting perspectives of various cultural systems.

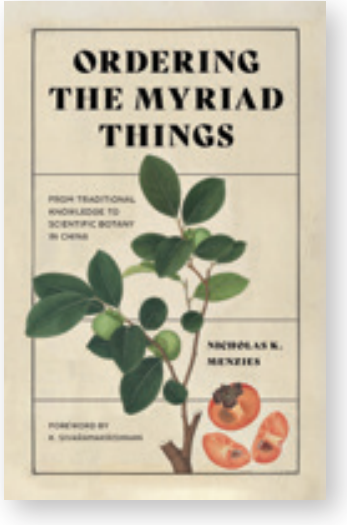

Ordering the Myriad Things

From Traditional Knowledge to Scientific Botany in China

Nicholas K. Menzies

$\$ 30.00$ S PB / ISBN 9780295749464

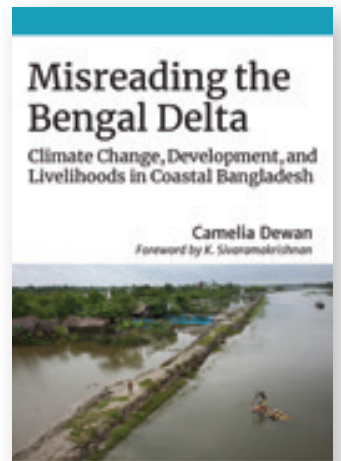

$\mathrm{N}=\mathrm{m}$

Misreading the Bengal Delta Climate Change, Development, and Livelihoods in Coastal Bangladesh Camelia Dewan $\$ 30.00$ S PB / ISBN 9780295749617 OA EDITION / DOI 10.6069/9780295749624

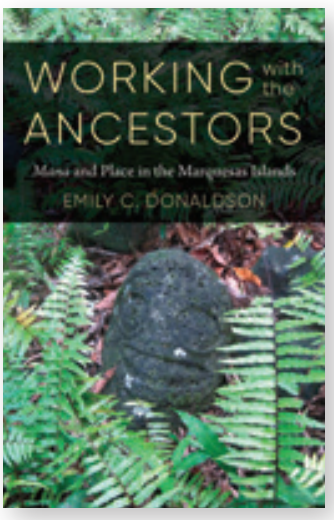

Working with the Ancestors Mana and Place in the Marquesas Islands

Emily C. Donaldson

$\$ 30.00$ S PB / ISBN 9780295745831

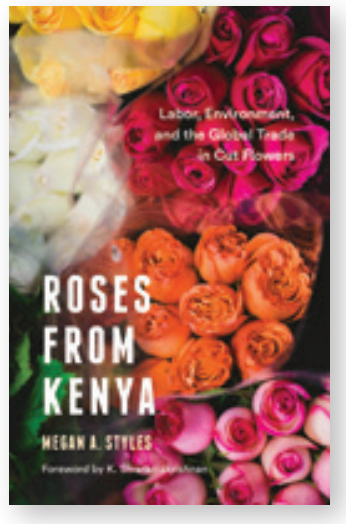

\section{Roses from Kenya}

Labor, Environment, and the Global Trade in Cut Flowers

Megan A. Styles

$\$ 30.00$ S PB / ISBN 9780295746500

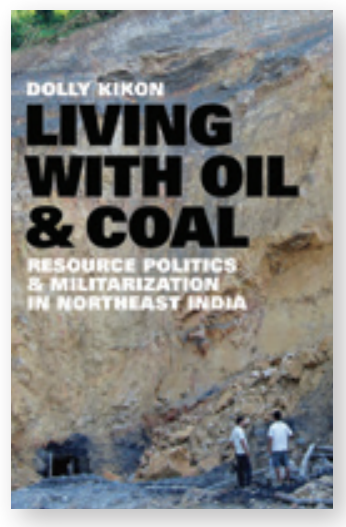

Living with Oil and Coal

Resource Politics and Militarization in Northeast India

Dolly Kikon

$\$ 30.00$ S PB / ISBN 9780295743950 


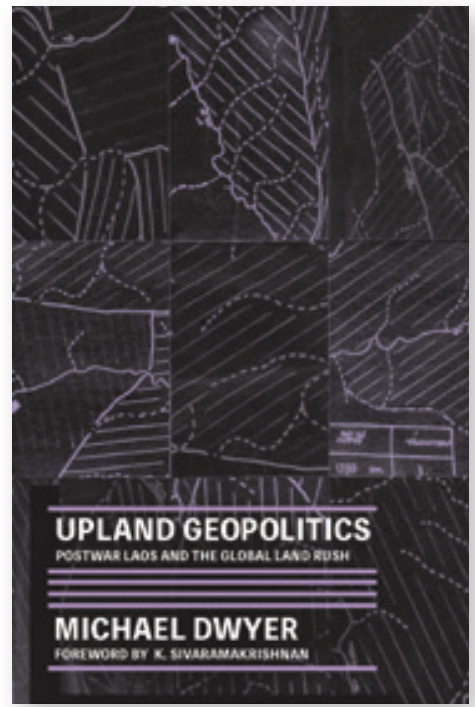

\section{Upland Geopolitics}

\section{Postwar Laos and the Global Land Rush}

\section{Michael Dwyer}

Foreword by K. Sivaramakrishnan

COLD WAR LEGACIES IN SOUTHEAST ASIA ENABLE NEW GEOGRAPHIES

OF ENCLOSURE

ASIAN STUDIES: SOUTHEAST ASIA | ANTHROPOLOGY | ENVIRONMENTAL STUDIES

$\$ 99.00 x$ / £79.00 HC / ISBN 9780295750484

$\$ 30.00$ S — £22.99 PB / ISBN 9780295750491

EBOOK EDITION / ISBN 9780295750507

IN THE TWENTY-FIRST CENTURY, TRANSNATIONAL LAND DEALS in the Global South have become increasingly prevalent and controversial. Widely seen as a new global land grab, transnational access to arable land in impoverished "land-rich" countries in Latin America, Sub-Saharan Africa, and Southeast Asia highlights the link between the shifting geopolitics of economic development and problems of food security, climate change, and regional and international trade. Drawing on ethnographic and archival research, Upland Geopolitics uses the case of Chinese agribusiness investment in northern Laos-one of China's first sustained forays into foreign land deals during the boom years of the early 2000 - - to study the unbalanced geography of the new global land rush. Contemporary Laos serves as a stage on which the growing frustration with traditional Western assistance is leading to new forms of SouthSouth development cooperation. Connecting the current rubber plantation boom to a longer trajectory of foreign intervention in the region, Upland Geopolitics reveals how legacies of Cold War conflict continue to pave the way for transnational enclosure in a socially uneven landscape.

Michael Dwyer is assistant professor of geography at Indiana University Bloomington.

"Dwyer adds historical depth as well as geographical nuance to how scholars have sought to understand Laos's recent territorialization." -JONATHAN RIGG, author of Rural Development in Southeast Asia: Dispossession, Accumulation and Persistence

"A strong contribution to the geopolitics of land grabbing in Southeast Asia, Upland Ceopolitics provides vital insights into the dynamics of dispossession."-ROBIN BIDDULPH, coeditor of Inclusive Tourism Development

CULTURE, PLACE, AND NATURE

JUNE

232 pp., 8 b\&w illus., 7 maps, $6 \times 9$ in. 


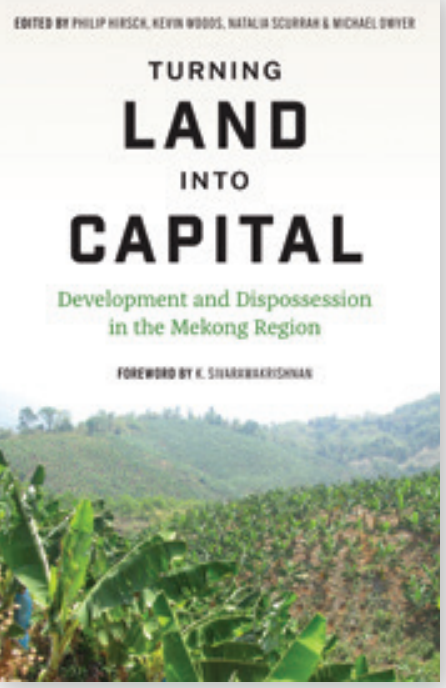

\section{Turning Land into Capital}

\author{
Development and Dispossession in the Mekong Region \\ Edited by Philip Hirsch, Kevin Woods, Natalia Scurrah, \\ and Michael Dwyer \\ Foreword by K. Sivaramakrishnan \\ UNDER THE GUISE OF DEVELOPMENT, LAND IS COMMODIFIED AT THE \\ EXPENSE OF THE RURAL POOR \\ ANTHROPOLOCY | ASIAN STUDIES: SOUTHEAST ASIA | ENVIRONMENTAL STUDIES \\ $\$ 99.00 \times$ / £79.00 HC / ISBN 9780295750453 \\ $\$ 30.00$ / f22.99 PB / ISBN 9780295750460 \\ $\$ 30.00$ S / f22.99 EB / ISBN 9780295750477
}

IN SOUTHEAST ASIA, REVERSALS OF EARLIER AGRARIAN REFORMS have rolled back "land-to-the-tiller" policies created in the wake of Cold War-era revolutions. This trend, marked by increased land concentration and the promotion of export-oriented agribusiness at the expense of smallholder farmers, exposes the convergence of capitalist relations and state agendas that expand territorial control within and across national borders. Through the lens of land capitalization, Turning Land into Capital examines the contradictions produced by superimposing twenty-first-century neoliberal projects onto diverse landscapes etched by decades of war and state socialism.

Chapters in the book explore geopolitics, legacies of colonialism, ideologies of development, and strategies to achieve land justice in Cambodia, Laos, Myanmar, Thailand, and Vietnam. The resulting picture reveals the place-specific interactions of state and market ideologies, regional geopolitics, and local elites in concentrating control over land.

Philip Hirsch is emeritus professor of human geography at the University of Sydney and coauthor of Powers of Exclusion: Land Dilemmas in Southeast Asia. Kevin Woods is a fellow at the East-West Center in Honolulu. Natalia Scurrah is an independent researcher based in Thailand and coauthor of The Mekong: A Sociolegal Approach to River Basin Development. Michael Dwyer is assistant professor of geography at Indiana University Bloomington and author of Upland Geopolitics: Postwar Laos and the Global Land Rush.
"A timely contribution to the field of agrarian studies, this book offers an insightful analysis of emerging trends in land use, land ownership, and growing inequality in the Mekong Region."-JONATHAN PADWE, University of Hawai'i Mānoa

\footnotetext{
"Turning Land into Capital will inspire additional work by providing close attention to land and agrarian transformation as a lens to illuminate broad political, social, and economic processes shaping and reshaping the region."-TYRELL HABERKORN, University of Wisconsin-Madison CULTURE, PLACE, AND NATURE A DONALD R. ELLEGOOD BOOK AUGUST 273 pp., 2 maps, 5 charts, 3 tables, $6 \times 9$ in.
} 

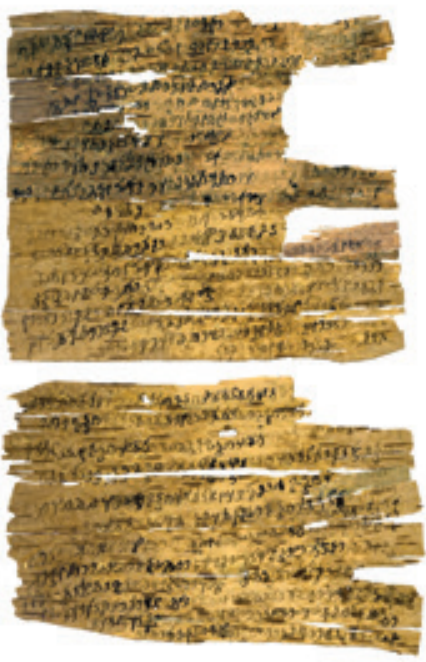

Three Early Mahāyāna Treatises from Gandhāra

\author{
Bajaur Kharoșthī Fragments 4, 6, and 11
}

VOLUME 7

Andrea Schlosser

BUDDHIST TEXTS ON THE PATH TO LIBERATION

ASIAN STUDIES | HISTORY

$\$ 99.00 /$ f79.00 HC / ISBN 9780295750736

OA EDITION / DOI 10.6069/9780295750750
THE GANDHĀRAN BIRCH-BARK SCROLLS PRESERVE THE EARLIest remains of Buddhist literature known today and provide unprecedented insights into the history of Buddhism. This volume presents three manuscripts from the Bajaur Collection (BC), a group of nineteen scrolls discovered at the end of the twentieth century and named after their findspot in northwestern Pakistan. The manuscripts, written in the Gāndhārī language and Kharoșțhī script, date to the second century $\mathrm{CE}$. The three scrolls $-\mathrm{BC} 4, \mathrm{BC} 6$, and $\mathrm{BC} 11-$ contain treatises that focus on the Buddhist concept of non-attachment. This volume is the first in the Gandhāran Buddhist Texts series that is devoted to texts belonging to the Mahāyāna tradition.

There are no known versions of these texts in other Buddhist traditions, and it is assumed that they are autographs. Andrea Schlosser provides an overview of the contents of the manuscripts and discusses their context, genre, possible authorship, physical layout, paleography, orthography, phonology, and morphology. Transliteration and translation of the texts are accompanied by notes on difficult terminology, photographs of the reconstructed scrolls, an index of Gāndhārī words with Sanskrit and Pali equivalents, and a preliminary transliteration of the scroll BC 19.

Andrea Schlosser is research associate in the Buddhist Manuscripts from Gandhāra project at the Bavarian Academy of Sciences and Humanities in Munich.
"The significance of these texts ... cannot be underestimated." -Bulletin of the Asian Institute

GANDHĀRAN BUDDHIST TEXTS

\section{APRIL}

360 pp., 15 color plates, 33 b\&w illus., $8 \times 11$ in 


\title{
GANDHĀRAN BUDDHIST TEXTS
}

\author{
Series editors: Stefan Baums, Ingo Strauch, and Richard G. Salomon
}

The Gandhāran Buddhist Texts series presents text editions and studies of early Buddhist birch-bark scrolls in the Gāndhāri language, dating from about the first century BCE to the third century CE. These manuscripts, discovered in the ancient region of Gandhāra (modern Pakistan and Afghanistan), provide unprecedented insight into the early history of Buddhism as it was transmitted from India to Central Asia and China on its way to becoming a world religion. At the same time, as the earliest preserved manuscripts from South Asia, they are invaluable primary sources for the linguistic and literary history of the region.

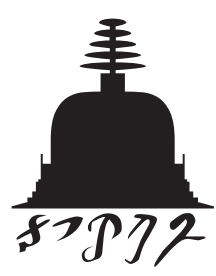

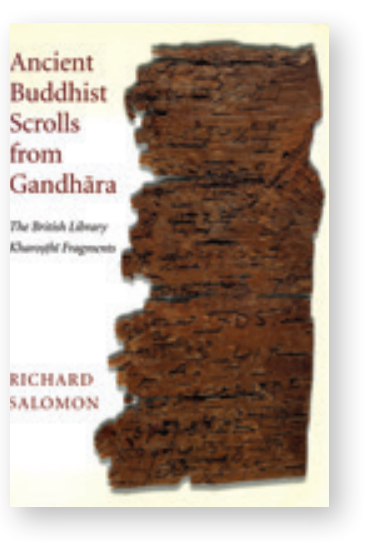

\section{Ancient Buddhist Scrolls from Gandhāra \\ The British Library Kharoșthī \\ Fragments \\ Richard Salomon \\ $\$ 50.00 \times$ PB / 9780295977690}

"A rare example of a book that appeals equally to the specialist... as well as to the general reader interested in archaeology or in Buddhist thought and practice."-Choice

\section{Four Gāndhārī}

Saṃyuktāgama Sūtras

Senior Kharoșthī Fragment 5

Andrew Stuart Glass

with Mark Allon

\$99.00X HC / 9780295987729

"A masterfully executed study. It will serve as a solid foundation for the future study of the rest of the Senior manuscripts and will provide new data for Gandhari lexicography. Class' work is nothing if not meticulous."-Bulletin of the Asia Institute

\section{A Gāndhārī Version of the Rhinoceros Sutra British Library Kharoșthī \\ Fragment $5 B$ \\ Richard Salomon \\ with Andrew Stuart Glass \\ $\$ 99.00 \times$ HC / 9780295980355}

\section{Three Cāndhārī Ekottarikāgama-}

\section{Type Sūtras}

British Library Kharoșthī Fragments 12 and 14

Mark Allon

with Andrew Stuart Class

$\$ 99.00 \times$ HC / 9780295981857

\author{
A New Version of the Gāndhāri \\ Dharmapada and a Collection of \\ Previous-Birth Stories \\ British Library Kharoșțī \\ Fragments $16+25$ \\ Timothy Lenz \\ with Andrew Stuart Class and \\ Bhikshu Dharmamitra \\ \$99.00x HC / 9780295983080
}

"The Gandhari canon may prove to be a crucial link in understanding the way Buddhism moved northward along the Silk Road, into Central and East Asia, even as it largely died out in India." -Chronicle of Higher Education

\section{Two Gāndhārī Manuscripts of the "Songs of Lake Anavatapta" (Anavatapta-gāthā) \\ British Library Kharoșțī Fragment 1 and Senior Scroll 14 \\ Richard Salomon \\ with Andrew Stuart Glass \\ $\$ 99.00 \times$ HC / 9780295989051}

"Whoever wants to learn how to handle really difficult fragmentary Buddhist or other texts with outstanding success should first carefully study and absorb this book." -Journal of the American Oriental Society

\section{Gandhāran Avadānas}

British Library Kharoșthī Fragments 1-3 and 21 and Supplementary

Fragments $A-C$

Timothy Lenz

$\$ 99.00 x$ HC / 9780295990132

"These schematic stories are fascinating puzzles, rough drafts for Buddhist literature to come, and Lenz is an excellent guide for making sense of them."

—Religious Studies Review 


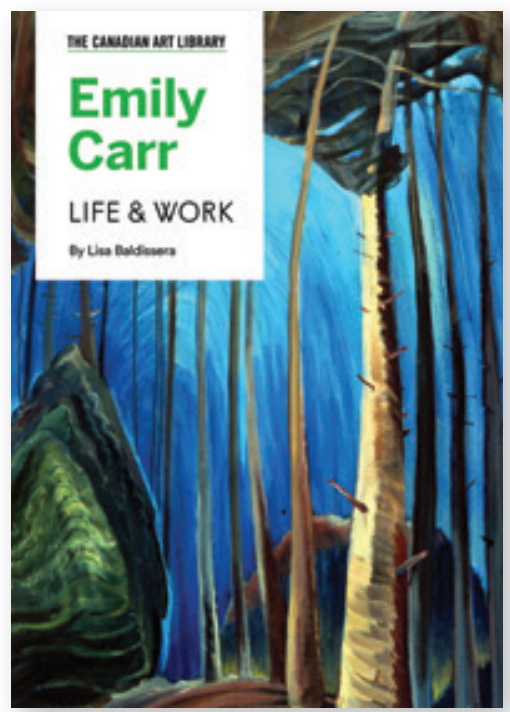

\section{Emily Carr}

Life \&Work

Lisa Baldissera

ART HISTORY | PAINTING

$\$ 45.00 \mathrm{HC} /$ ISBN 9781487102326

EMILY CARR (1871-1945) GAINED PROMINENCE WHEN FEMALE painters were not recognized internationally. Her work reveals a fascination with questions inspired by the Canadian sea, landscapes, and people, reflecting a profound commitment to the land she knew and loved. Along with the Group of Seven, Carr became a leading figure in Canadian modern art. Although more than half a century has passed since her death, her paintings continue to challenge and inspire.

Emily Carr: Life \& Work traces Carr's trajectory from her early years in Victoria, where she struggled to receive acceptance, to her eventual status as one of Canada's most influential painters. With insight and intelligence, Lisa Baldissera shows how Carr, despite enduring hardships and rejection, persevered to create an iconic vision. This book also explores Carr's extensive travels, during which she learned from European, American, and Indigenous forms; received formal training at art academies and from private tutors; and experimented with a variety of media. Through it all, she grew in creative power, producing work that remains relevant today.

Lisa Baldissera is the director of Griffin Art Projects in North Vancouver. She has worked in curatorial roles for public art galleries in Western Canada and as an independent curator, consultant, and writer for nearly twenty years. 


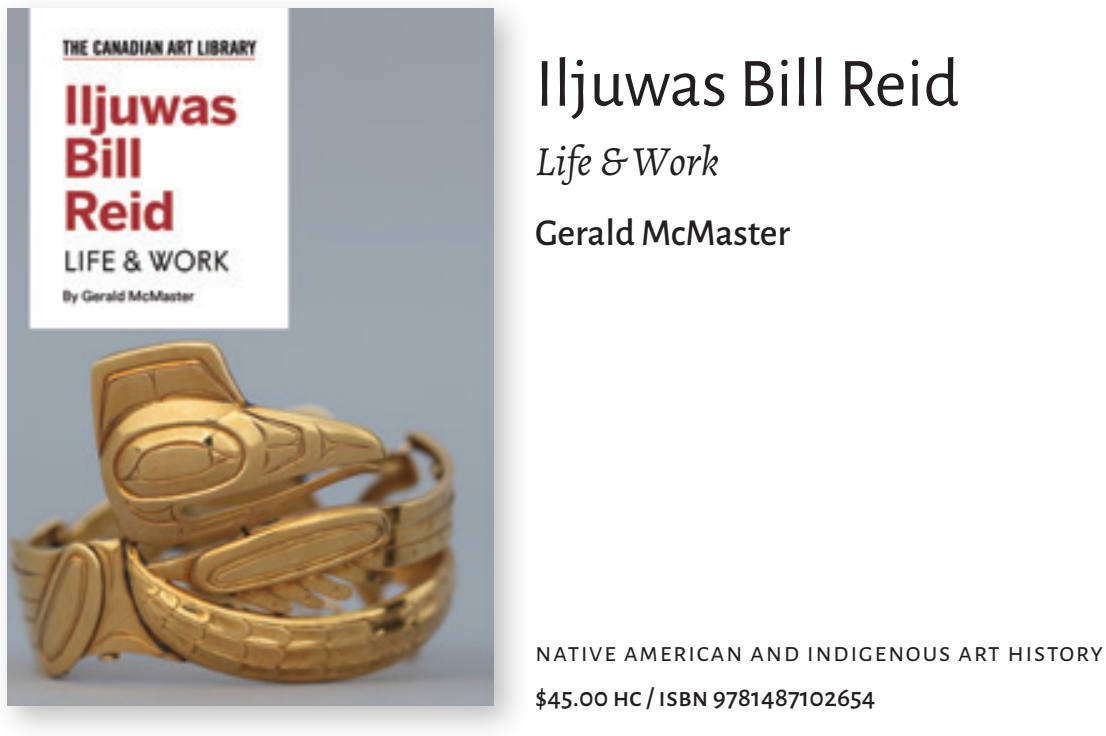

FEW TWENTIETH-CENTURY ARTISTS WERE CATALYSTS FOR THE reclamation of a culture, but Iljuwas Bill Reid (1920-1998) was among them. This first book on Reid by an Indigenous scholar details his incredible journey to becoming one of the most significant Northwest Coast artists of our time. Born in British Columbia and denied his mother's Haida heritage in his youth, Reid lived the reality of colonialism yet tenaciously forged a creative practice that celebrated Haida ways of seeing and making. Reid followed in the footsteps of his great-great-uncle, master Haida artist Daxhiigang (Charles Edenshaw), engaging with a culture whose practices were once banned by the Indian Act. Reid, who created nearly a thousand original works, is remembered as a passionate artist, community activist, mentor, and writer. His iconic large-scale works now occupy sites such as the Canadian Embassy in Washington, DC, and the Museum of Anthropology at the University of British Columbia.

Gerald McMaster, OC, is one of Canada's most esteemed academics. A curator, artist, and author, he is currently professor and Tier 1 Canada Research Chair of Indigenous Visual Culture and Curatorial Practice at OCAD University, where he leads a team of researchers at the Wapatah Centre for Indigenous Visual Knowledge. He is nêhiyaw (Plains Cree) and a citizen of the Siksika First Nation. 


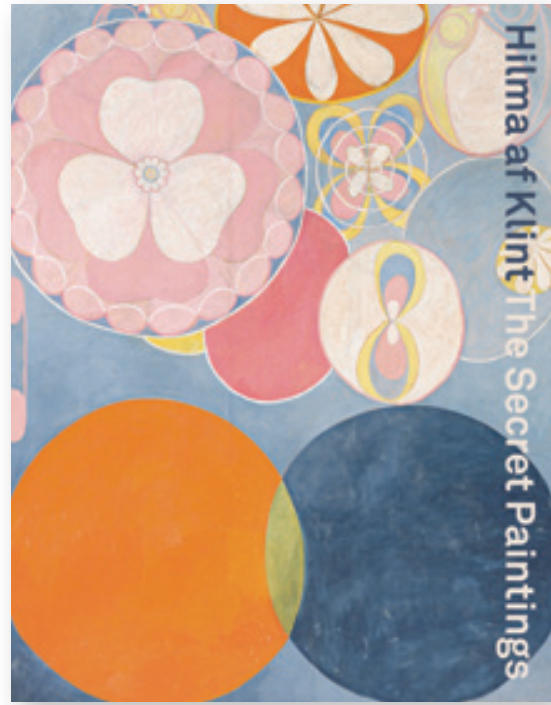

\section{Hilma af Klint}

\section{The Secret Paintings}

\section{Edited by Sue Cramer with Nicholas Chambers}

Essays by Sue Cramer, Nicholas Chambers, Jennifer Higgie,

Aaron Lister, and Julia Voss

HILMA AF KLINT, VISIONARY ARTIST AND ABSTRACT ART PIONEER

ART HISTORY | PAINTINC

$\$ 50.00 \mathrm{HC} /$ ISBN 9781741741520
HIDDEN FROM VIEW FOR DECADES, THE WORK OF HILMA AF Klint (1862-1944) has captured the imagination of contemporary audiences. She is now widely regarded as a pioneer of twentiethcentury abstract art. Her paintings are monumental in scale, with radiant color combinations, enigmatic symbols, and otherworldly shapes. In an era of limited creative freedom for women, her secret paintings were an outlet for her prodigious intelligence, spiritual quest, and groundbreaking artistic vision.

Hilma af Klint: The Secret Paintings includes over 125 artworks, ranging from enormous canvasses to small watercolors; pages from her detailed notebooks; and a selection of photographs and other images. Five essays and an illustrated chronology reveal new research on af Klint, her practice, and her place in art history.

Sue Cramer is an independent curator and writer. Nicholas Chambers is senior curator of modern and contemporary international art at the Art Gallery of New South Wales, Sydney. Jennifer Higgie is author of The Mirror \& the Palette: Rebellion, Revolution and Resilience: 500 Years of Women's Self-Portraits and other works. Aaron Lister is senior curator at City Gallery Wellington Te Whare Toi in Aotearoa New Zealand. Julia Voss is author of Hilma af Klint: "Die Menschheit in Erstaunen versetzen," a biography of af Klint. 


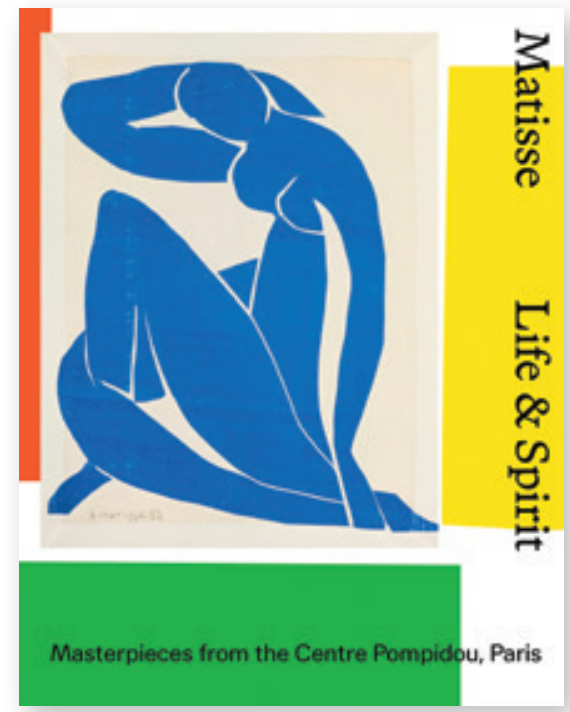

\title{
Matisse
}

\author{
Life \& Spirit
}

\section{Edited by Aurélie Verdier with Justin Paton} and Jackie Dunn

With essays by Roger Benjamin, Patrice Deparpe, Justin Paton, Aurélie Verdier, and Alastair Wright and contributions by Anne Théry and Marjolaine Beuzard

ART HISTORY

$\$ 60.00 / £ 48.00 \mathrm{HC} /$ ISBN 9781741741537

MATISSE: LIFE $\mathcal{E}$ SPIRIT PRESENTS AN IMMERSION IN THE

range and depth of the art of Henri Matisse, one of the world's most beloved and innovative artists. The works reach from his early adventures in color as a Fauvist through to the serene designs for his chapel in the south of France. Through paintings, drawings, sculptures, and cut-outs, this collection reveals how Matisse renewed his vision time and again, seeking new ways to celebrate the seen world and express the energy he felt in it.

Highlights include the important early work Le luxe I; the midcareer masterpiece Decorative Figure on an Ornamental Ground; and the majestic self-portrait The Sorrow of the King.

Filled with brilliant color, dynamic energy, and emotional power, Matisse: Life \& Spirit offers an inspirational journey through the life and art of an inventive and life-affirming painter.

Aurélie Verdier is curator of modern art at the Centre Pompidou. Justin Paton is head curator of international art at the Art Gallery of New South Wales, Sydney. Jackie Dunn is special exhibitions curator at the Art Gallery of New South Wales. Roger Benjamin is professor of art history at the University of Sydney. Marjolaine Beuzard is assistant curator at the Centre Pompidou. Patrice Deparpe is director of the Matisse Museum in Cateau-Cambrésis, France. Anne Théry was a researcher at the Centre Pompidou and is now at the Matisse Archives. Alastair Wright is associate professor of the history of art at St John's College, Oxford.

\section{AVAILABLE}

264 pp., 100 color illus., $10.5 \times 8.5$ in. NORTH AMERICAN RIGHTS ONLY 


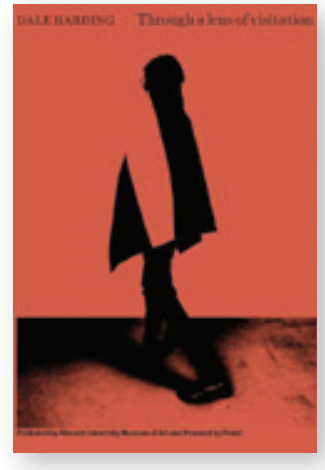

\section{Dale Harding}

Through a Lens of Visitation

Edited by Hannah Mathews and Dale Harding

With texts by Deborah Edwards, Nancy Underhill, Ann

Stephen, Jackie Huggins, and Paul S. C. Taçon

\section{A CO-PUBLICATION FROM MONASH UNIVERSITY MUSEUM OF ART AND POWERED BY POWER}

Through a Lens of Visitation pays homage to the stories and presence of matrilineal figures in Dale Harding's family. It documents a first-time collaboration with his mother, textile artist Kate Harding, who uses quilt-making to tell stories of family, culture, and country. Her quilts and his painterly responses together reflect on cultural knowledge as it is held, practiced, and transposed across generations, gender, and place.

Dale Harding uses painting, sculpture, stencilling, and woodcarving to produce work informed by his heritage as a descendant of Australia's Bidjara, Ghungalu, and Garingbal peoples. Hannah Mathews is senior curator at the Monash University Museum of Art. Deborah Edwards is a freelance curator and writer. Nancy Underhill is an art historian, curator, lecturer, and author. Ann Stephen is an art historian and curator. Jackie Huggins is a writer, historian, and activist. Paul Taçon has published widely on rock art, material culture, color, cultural evolution, and identity.

\section{AVAILABLE}

ART

158 pp., 121 illus., including color plates, $13.5 \times 10$ in. NORTH AMERICAN RIGHTS ONLY

$\$ 35.00 \mathrm{HC} /$ ISBN 9780648152989

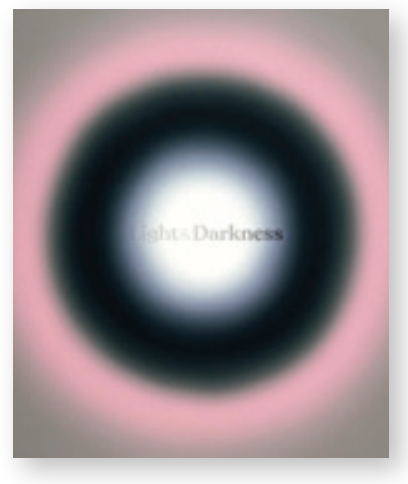

\section{Light \& Darkness}

Late Modernism and the JW Power Collection

Edited by Ann Stephen

A CO-PUBLICATION FROM SYDNEY UNIVERSITY'S POWER PUBLICATIONS AND THE CHAU CHAK WINC MUSEUM

Light \& Darkness offers a unique perspective on the twentyfive-year history and evolution of the JW Power Collection, one of the most significant art collections of local and international art in Australia. It explores luminosity, color, movement, race, gender, and politics across three decades of late modernism, introducing this collection to a new generation. This volume also features essays from prominent art historians and curators, including an illuminating introduction by art historian and curator Ann Stephen.

"A revelation ... Under curator Ann Stephen's deft editorial hand, some 70 works from the 1500 in the Power Collection point to key directions - the wonderful luminal and kinetic works from the late 1960s; the diversity of the 1970s, ranging from Jasper Johns to On Kawara; the turn in the 1980 s to collecting art from Australia and New Zealand. All these works are illuminated by fresh research, in probing essays showing that scholarship is the flame that sustains all museums."-JULIE EWINGTON, independent writer, curator, and broadcaster, Sydney, and former head of Australian art, QAOMA, Brisbane

\section{AVAILABLE}

ART

239 pp., 120 images, including color plates, $10.5 \times 9$ in.

NORTH AMERICAN RIGHTS ONLY

$\$ 35.00$ PB / ISBN 9780909952020 


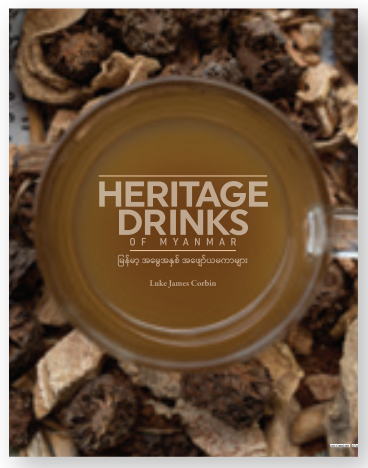

\section{Heritage Drinks of Myanmar}

\section{Luke James Corbin}

Photographs by Shwe Paw Mya Tin

Heritage Drinks of Myanmar takes the reader on an anthropological journey through emerald mountains and rust-red valleys to showcase some of the myriad alcoholic drinks made in this unique and fascinating country. In Myanmar, freshly brewed and distilled beers, wines, and spirits are integral parts of village economies, providing health, communal, and financial benefits. Rice whiskeys infused with insects and fresh beers made from a cornucopia of grains await eager drinkers, brewed as they have been for generations by village residents with their own individual customs and traditions.

Drinking has long been interwoven with diverse human expression, ritual, relaxation, and desire, and Myanmar's heritage drinks are here exquisitely photographed and detailed through exhaustive interviews with village producers. Pick it up, drink it in, and enjoy a libation as your mind wanders to the Golden Land.

Luke J. Corbin is a brewer and researcher who has lived in Myanmar since 2016. He holds multiple degrees from the College of Asia \& the Pacific at the Australian National University. Shwe Paw Mya Tin is a Yangon-based freelance photographer who provides photographs for NCOs, INCOs, and local and international news agencies.

\section{MARCH}

ASIAN STUDIES: SOUTHEAST ASIA

100 pp., 99 color illus., $10 \times 12$ in.

WORLD, EXCEPT SOUTHEAST ASIA

$\$ 65.00$ HB / ISBN 9786162151804

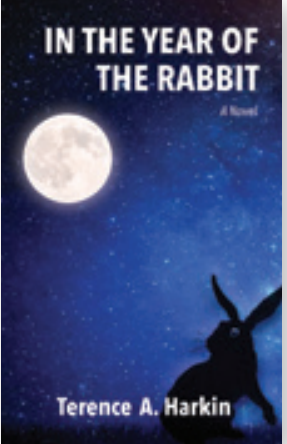

\section{In the Year of the Rabbit: A Novel}

Terence A. Harkin

After surviving an ambush in which his lover was killed, cameraman Brendan Leary numbly returns to combat, flying night operations over the mountains of Laos. Leary is later discharged but remains in Thailand. He is ordained as a Buddhist monk and embarks on a pilgrimage through the wastelands of Laos, haunted by what Thais call pii tai hong - the restless, unhappy ghosts of his doomed crewmates.

A sequel to The Big Buddha Bicycle Race, this story of healing and redemption honors three groups missing from accounts of the Vietnam War - the air commandos who risked death flying nightly over the Ho Chi Minh Trail, the active-duty airmen who risked prison by joining the $\mathrm{Gl}$ antiwar movement, and the people of neutral Laos, whose lives and country were devastated.

Terence A. Harkin won the 2020 Silver Medal in Literary Fiction from the Military Writers Society of America for his debut novel, The Big Buddha Bicycle Race. During the Vietnam War he served with the USAF photo unit operating out of Ubon, Thailand. He has returned often to Thailand and Laos.

"Makes a strong, significant, even surprisingly unique contribution to the large body of fiction that has emerged from the Vietnam War. For anyone who wishes to fully examine that most emblematic of American wars, In the Year of the Rabbit is essential reading." - ROBERT OLEN BUTLER, Pulitzer Prize-winning author of Good Scent from a Strange Mountain

\section{MARCH}

FICTION

316 pp., $5.5 \times 8.5 \mathrm{in}$.

WORLD, EXCEPT SOUTHEAST ASIA

$\$ 18.95$ PB / ISBN 9786162151767 


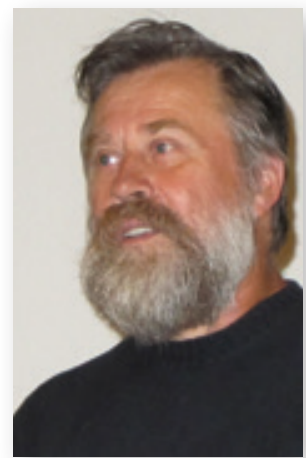

\section{Dream Bridge}

\section{Selected Poems by Oleh Lysheha}

\section{Translated by Virlana Tkacz and Wanda Phipps}

In this collection, Oleh Lysheha creates worlds in which horses drawn on Paleolithic caves speak their truths and the glance of a swan can transform a lost soul. Each poem leads us down an invisible path that keeps shifting, transforming us and our ideas of poetry, together with the story. In a concluding essay, artistic director Virlana Tkacz relates the story of the translations collected in this volume and the productions she staged with them at La MaMa Experimental Theatre in New York.

Oleh Lysheha (1949-2014) was born in Ukraine. He is author of several collections of poetry, including The Great Bridge, To Snow and Fire, and Winter in Tysnmenytsia. Virlana Tkacz heads the Yara Arts Group and has directed almost forty original shows at La MaMa Theatre in New York. Wanda Phipps is author of Mind Honey and other poetry collections. Together, Tkacz and Phipps have received the Agni Poetry Translation Prize, the National Theatre Translation Fund Award, and thirteen translation grants from the New York State Council on the Arts.

\section{LOST HORSE PRESS CONTEMPORARY UKRAINIAN} POETRY SERIES

\section{MAY}

POETRY

160 pp., $5.5 \times 8.5$ in.

$\$ 24.00$ PB / ISBN 9781736432372

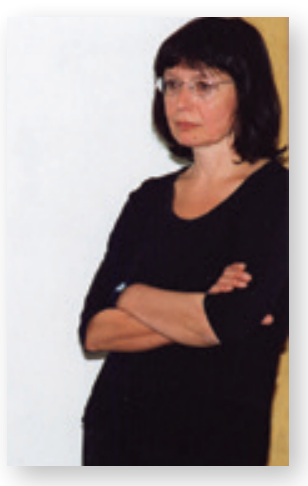

\section{Three Wooden Trunks}

\section{Virlana Tkacz}

Virlana Tkacz's Three Wooden Trunks is a collection of poems about memory, the poet's Ukrainian roots, and the poet's family's pursuit of a sweeter, easier life in America.

Virlana Tkacz is a literary translator and a scholar of Ukrainian modernism. She is also a theatre director and head of the Yara Arts Group, a resident company at La MaMa Experimental Theatre in New York City. Her original productions for Yara have been performed on three continents.

\section{MAY}

POETRY

86 pp., $5.5 \times 8.5$ in.

WORLD, EXCEPT SOUTHEAST ASIA

$\$ 20.00$ PB / ISBN 9781736432365 


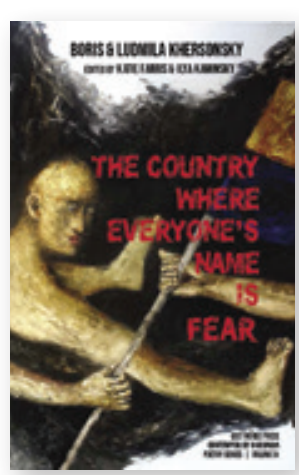

\section{The Country Where Everyone's}

\section{Name Is Fear}

\section{Selected Poems by Boris and Ludmila Khersonsky \\ Edited by Katie Farris and Ilya Kaminsky}

Boris and Ludmila Khersonsky write poetry that speaks to the crisis of our time, when refugees run from bombardments, nonstop propaganda flows from TV, and neighbors begin to hate their neighbors. The setting is Ukraine at the start of the twenty-first century, but it is eerily recognizable anywhere.

These brief lyric poems speak about the memory of historical trauma and witness stark individual voices that pierce the wall of complacency. What is the music of such times? What is its metaphysics? This collection gives us an unflinching, memorable response.

Boris Khersonsky is one of Ukraine's most prominent Russian-language poets. In Soviet times, he was a part of the Samizdat movement, which disseminated alternative, nonconformist literature. Ludmila Khersonsky is author of three collections of poetry and a professional translator. Her poetry has been honored with the Voloshin Prize and translated into several languages. Katie Farris is author of Boysgirls and coeditor of Cossip and Metaphysics: Russian Modernist Poets. She is a recipient of the Chad Walsh Chapbook Prize and the Anne Halley Poetry Prize. Ilya Kaminsky is author of Dancing in Odessa and DeafRepublic. He is a recipient of the Los Angeles Times Book Prize and a Cuggenheim Fellowship.

\section{MAY}

POETRY

120 pp., $5.5 \times 8.5$ in

$\$ 20.00$ PB / ISBN 9781736432358

\section{In Memory of a Banyan Tree}

\author{
Poems of the Outside World, 1985-2022 \\ Michael Rothenberg
}

In Memory of a Banyan Tree is a collection of poems relating to nature, ecology, and ecopoetics, selected from the expanse of Rothenberg's writings over the past thirty-five years. Rothenberg's many years as a horticulturist and his engagement in the environmental movement inform his work. These poems are a watershed account of an intimate relationship with the outside world.

Michael Rothenberg is editor and publisher of the online literary magazine BigBridge.org, cofounder of 100 Thousand Poets for Change (http://www.10otpc.org), and cofounder of Poets In Need, a nonprofit assisting poets in crisis. Born in Miami Beach, Florida, Rothenberg moved to the San Francisco Bay Area and cofounded Shelldance Orchid Gardens, which is dedicated to the cultivation of orchids and bromeliads. While in Pacifica, he helped lead local environmental actions that stopped major coastal developments that would destroy wildlife habitat. His books of poetry include The Pillars and I Murdered Elvis. Rothenberg currently lives on Lake Jackson in Tallahassee, where he is Florida State University Libraries Poet in Residence.

\section{MAY}

POETRY

86 pp., $5.5 \times 8.5$ in

$\$ 18.00$ PB / ISBN 9781736432341 


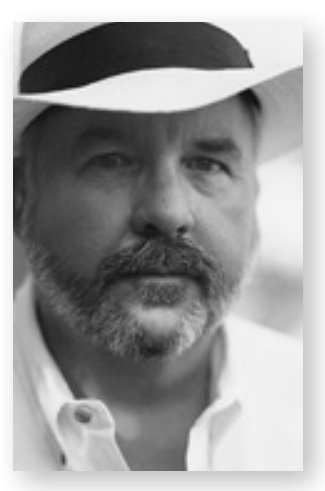

\section{The Consolations of Science and Philosophy}

\section{Poems by Christopher Buckley}

Christopher Buckley's latest book continues his exploration of how, despite the intellectual tools of science and philosophy, we are still somehow left with questions about identity, memory, love, loss, value, self, and Cod-not to mention the depredations of war. In his poetry and nonfiction, he has considered these matters in the belief that the answers to their mysteries are in the very act of pursuit. On every page is the work of a consummate artist who is also, recognizably, a companion spirit on the journey all of creation has been on all this time.

\section{Praise for Christopher Buckley's work:}

"Straightforward, intensely lyrical, and totally accessible. This is a humble poetry of great truths and profound emotions."

-PHILIP LEVINE, in Ploughshares

"Buckley's gift for wide-ranging thinking meshes so gracefully with lovingly tender details, he feels like a companion voice for all time ... and we are caught up in a spell of unfolding images, an arc of compelling music, and his passionate care for what we can and cannot change."-NAOMI SHIHAB NYE

"Buckley has an exquisite ear for language and a gutsy way of blending bravado with humility."-Library Journal

\section{MARCH 2021}

POETRY

$118 \mathrm{pp} ; 6 \times 8.5 \mathrm{in}$.

$\$ 18.95$ PB / ISBN 9780899241838

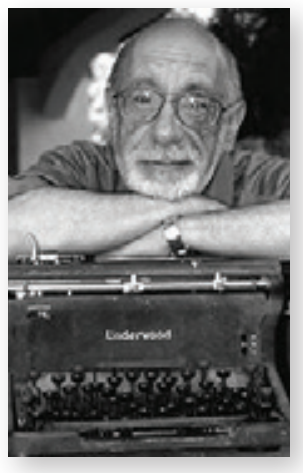

\section{Everybody}

Poems by Albert Goldbarth

For five decades Albert Coldbarth has been astonishing readers with the erudition, wit, lyric invention, wisdom, and depthless humanity of his prolific writing. He has won the National Book Critics Circle Award for Poetry twice and has been awarded the Mark Twain Prize for humor in poetry, the Chad Walsh Poetry Prize, fellowships from the Guggenheim Foundation and the National Endowment for the Arts, and other honors. He mixes complex ideas, wildly dissimilar objects and facts, detailed descriptions, striking lyricism, puns, coinages, and jargons. In his review in Slant, Eric McHenry wrote, "in spite of this omnivorousness, the poems aren't just big maximalist messes. Synthesis is Goldbarth's goal and his gift."

Praise for Albert Goldbarth's work:

“Coldbarth's prodigious output is matched only by his erudition. He seems to have read and ingested centuries of history, biology, and religion. At home in a dozen different masks, he is witty, irreverent, and full of forgiveness for our human condition."

-MAXINE KUMIN

"Albert Goldbarth is a truly remarkable phenomenon. He straddles the ages, one foot on the big bang and the other on last Saturday, a quark, a Rembrandt, a wooly mammoth, and a zillion sweet details curatorially, passionately gathered and balanced on the tip of his astonishing tongue." —DONALD FIN KEL

\author{
APRIL \\ POETRY \\ 108 pp., $6 \times 8.5$ \\ $\$ 18.95$ PB / ISBN 9780899241845
}




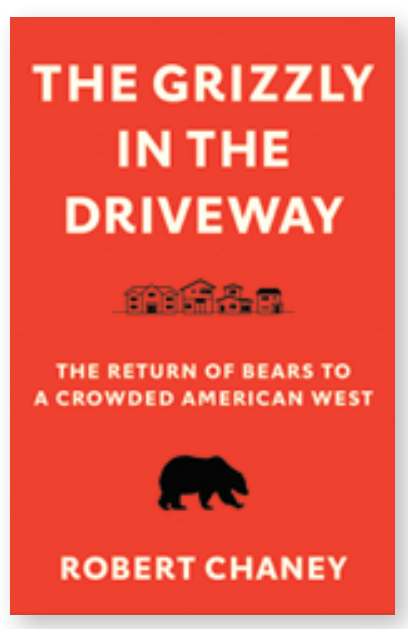

The Grizzly in the Driveway The Return of Bears to a Crowded American West

Robert Chaney

$\$ 29.95$ HC / ISBN 9780295747934

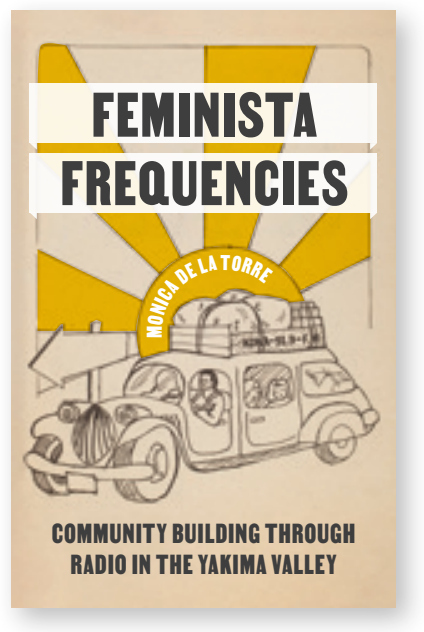

Feminista Frequencies

Community Building through Radio in the Yakima Valley

Monica De La Torre

\$27.95 PB / ISBN 9780295749662

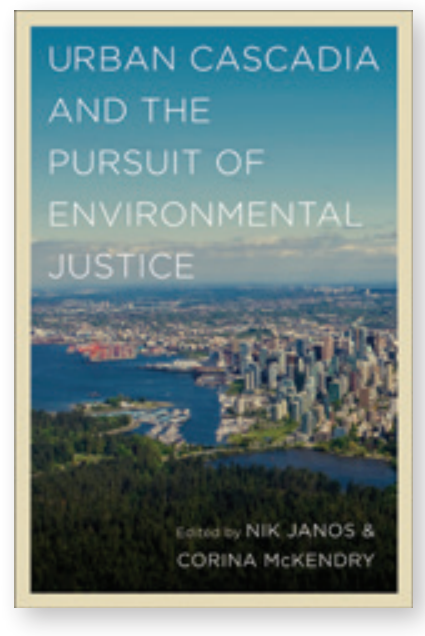

Urban Cascadia and the Pursuit of Environmental Justice Edited by Nik Janos and Corina McKendry $\$ 30.00$ S PB / ISBN 9780295749365

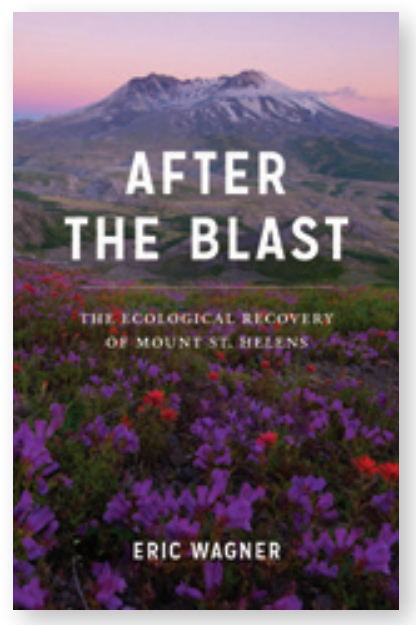

After the Blast

The Ecological Recovery of Mount St. Helens

Eric Wagner

\$19.95 PB / ISBN 9780295750712

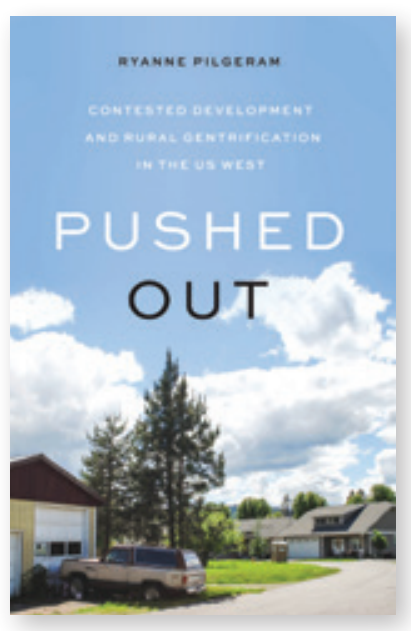

\section{Pushed Out}

Contested Development and Rural Gentrification in the US West Ryanne Pilgeram $\$ 30.00$ S PB / ISBN 9780295748696

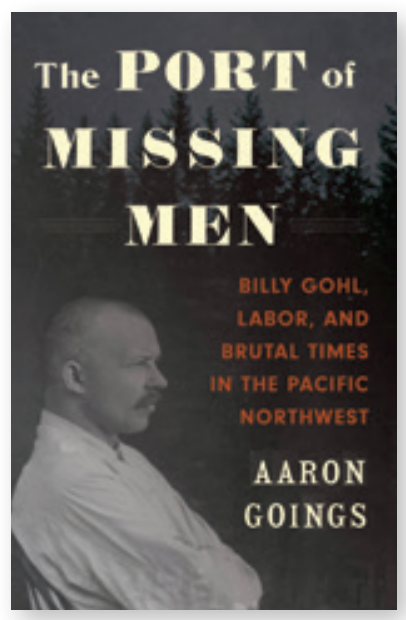

The Port of Missing Men

Billy Gohl, Labor, and Brutal Times in the Pacific Northwest

Aaron Goings

\$29.95 HC / ISBN 9780295747415 


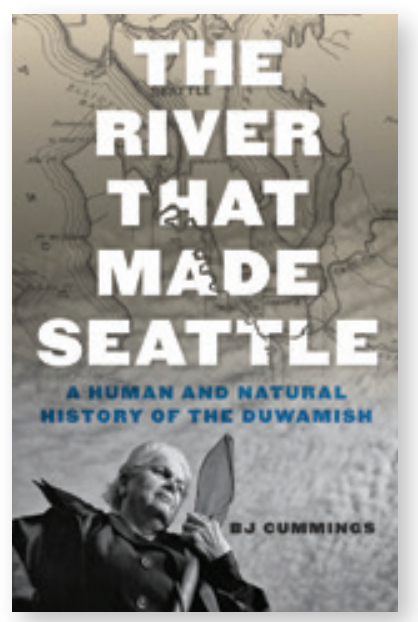

The River That Made Seattle A Human and Natural History of the Duwamish

B] Cummings

$\$ 29.95$ HC / ISBN 9780295747439

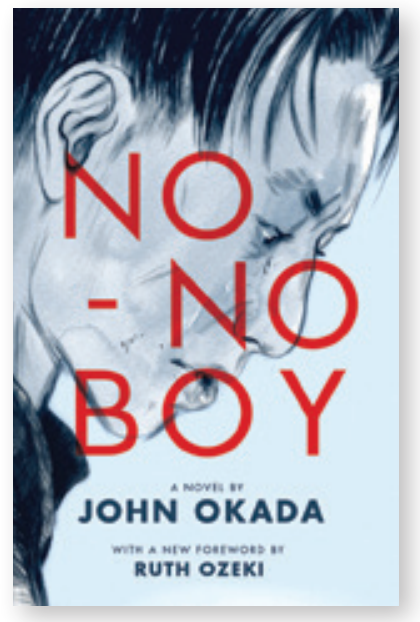

No-No Boy

John Okada

Foreword by Ruth Ozeki

Introduction by Lawson Fusao Inada and Frank Chin

$\$ 17.95$ PB / ISBN 9780295994048

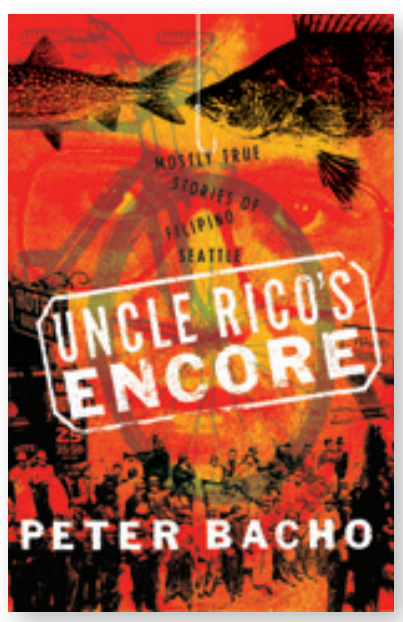

\section{Uncle Rico's Encore}

Mostly True Stories of Filipino Seattle Peter Bacho

\$24.95 HC / ISBN 9780295749778

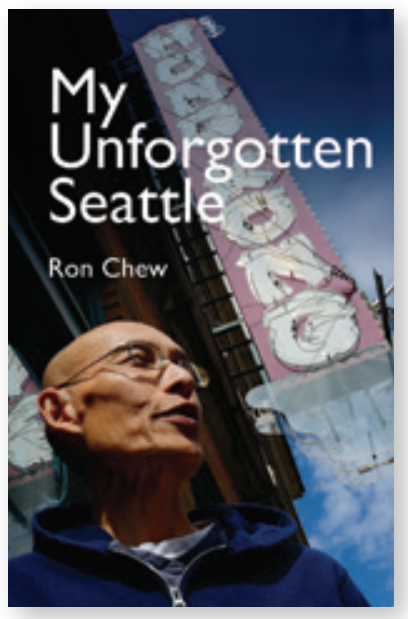

My Unforgotten Seattle Ron Chew

Foreword by Carey Quan Celernter \$39.95 HC / ISBN 9780295748412

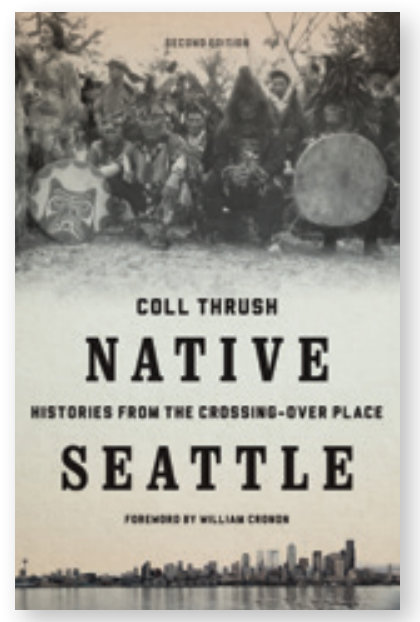

\section{Native Seattle}

Histories from the Crossing-Over Place SECOND EDITION

Coll Thrush

Foreword by William Cronon \$24.95 PB / ISBN 9780295741345

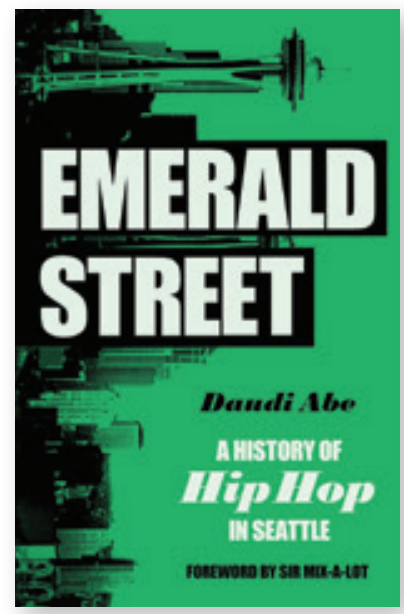

\section{Emerald Street}

A History of Hip Hop in Seattle

Daudi Abe

Foreword by Sir Mix-A-Lot

$\$ 29.95$ PB / ISBN 9780295747569 


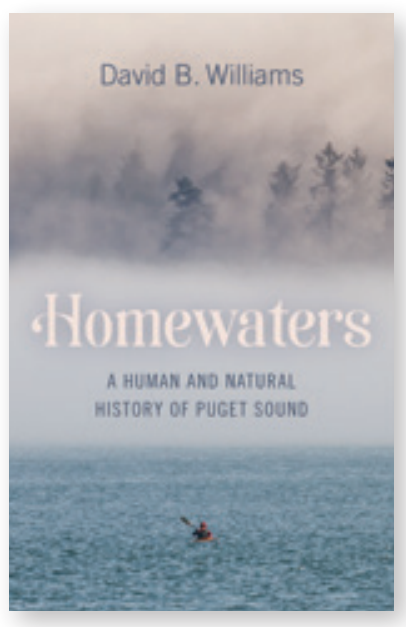

\section{Homewaters}

A Human and Natural History of Puget Sound

David B. Williams

$\$ 29.95$ HC / ISBN 9780295748603

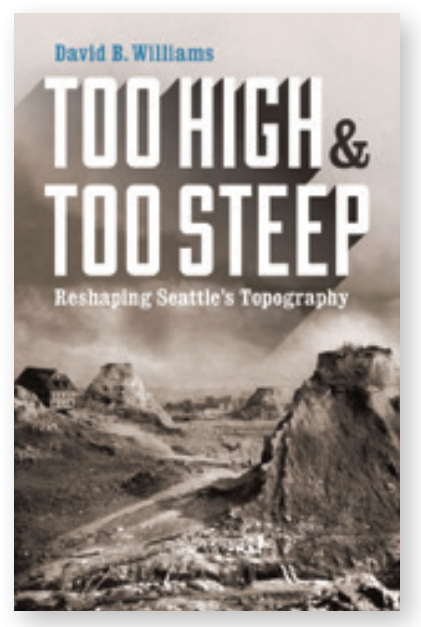

Too High and Too Steep

Reshaping Seattle's Topography

David B. Williams

$\$ 18.95$ PB / ISBN 9780295999401

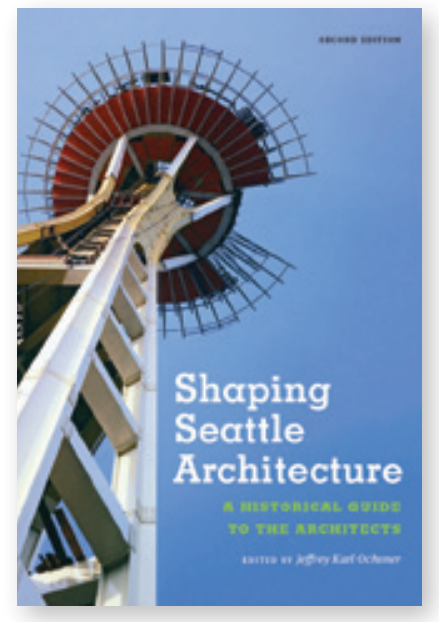

Shaping Seattle Architecture A Historical Guide to the Architects SECOND EDITION

Edited by Jeffrey Karl Ochsner $\$ 39.95$ PB / ISBN 9780295746449

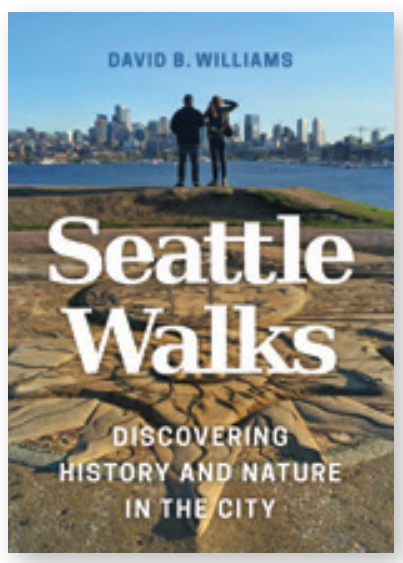

\section{Seattle Walks}

Discovering History and Nature in the City

David B. Williams

$\$ 18.95$ PB / ISBN 9780295741284

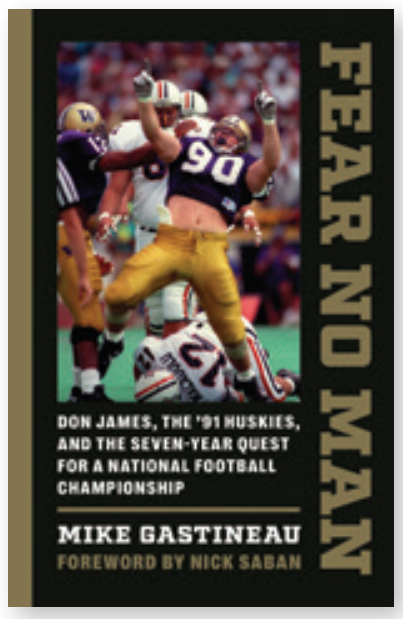

\section{Fear No Man}

Don James, the' 91 Huskies, and the Seven-Year Quest for a National Football Championship

Mike Gastineau

Foreword by Nick Saban

\$29.95 HC / ISBN 9780295749211 

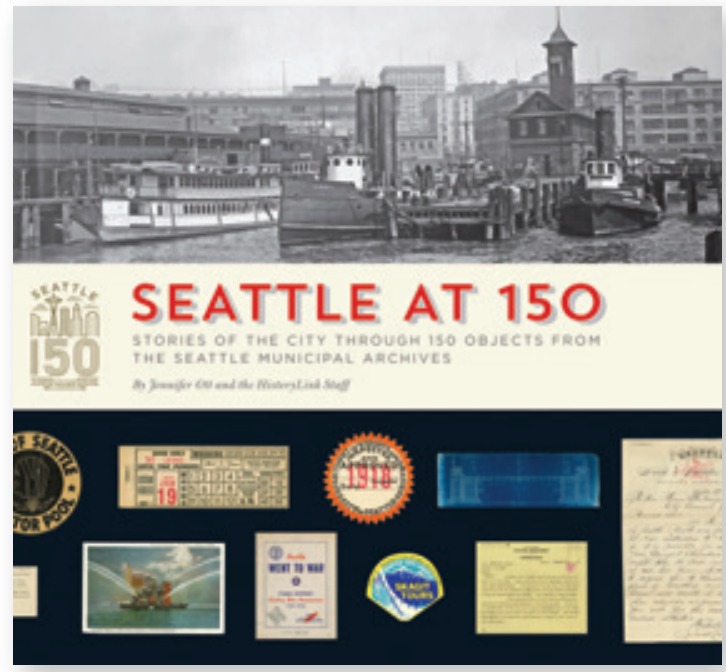

\section{Seattle at 150}

Stories of the City through 150 Objects from

the Seattle Municipal Archives

Jennifer Ott and the HistoryLink Staff

$\$ 34.95$ PB / ISBN 9781933245584
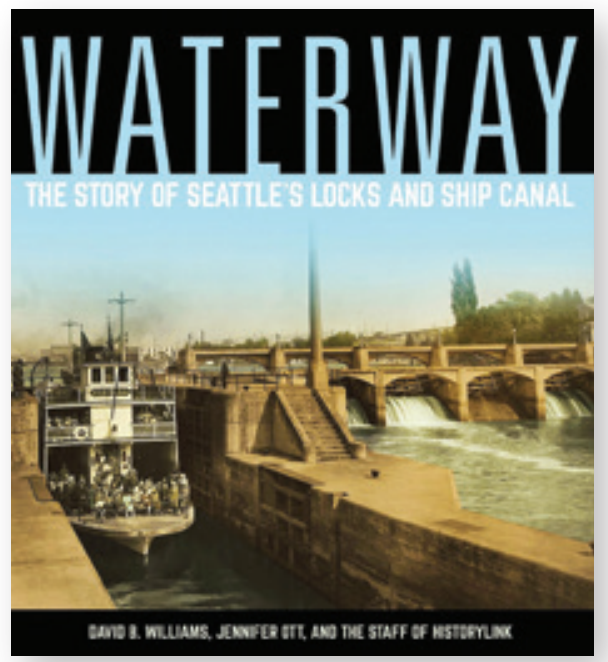

\section{Waterway}

The Story of Seattle's Locks and Ship Canal

David B. Williams, Jennifer Ott, and the Staff of HistoryLink $\$ 24.95$ PB / ISBN 9781933245430

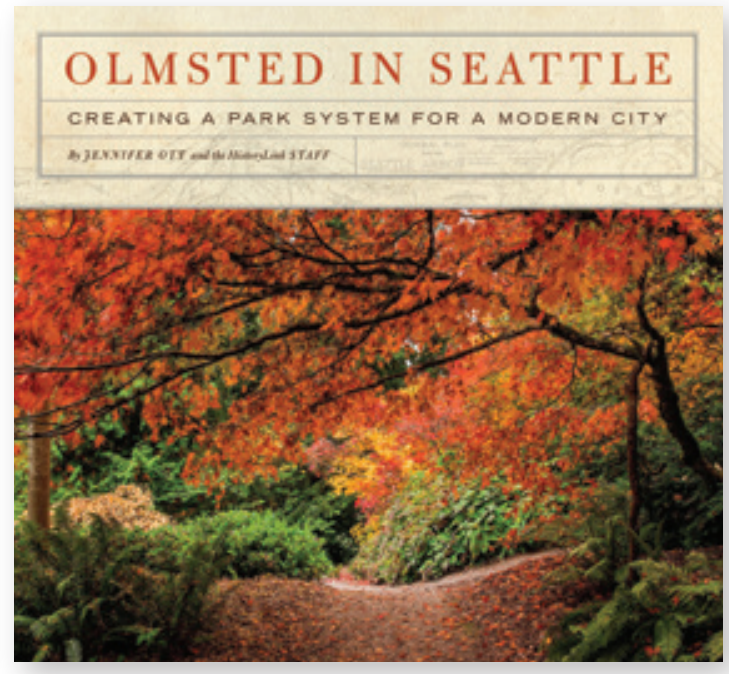

\section{Olmsted in Seattle}

Creating a Park System for a Modern City Jennifer Ott and the HistoryLink Staff $\$ 29.95$ PB / ISBN 9781933245560

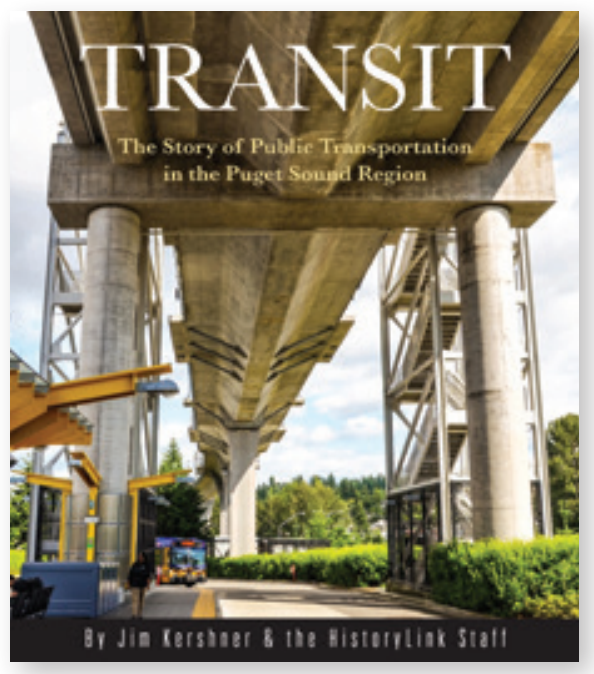

\section{Transit}

The Story of Public Transportation in the Puget Sound Region Jim Kershner and the HistoryLink Staff $\$ 29.95$ PB / ISBN 9781933245553 


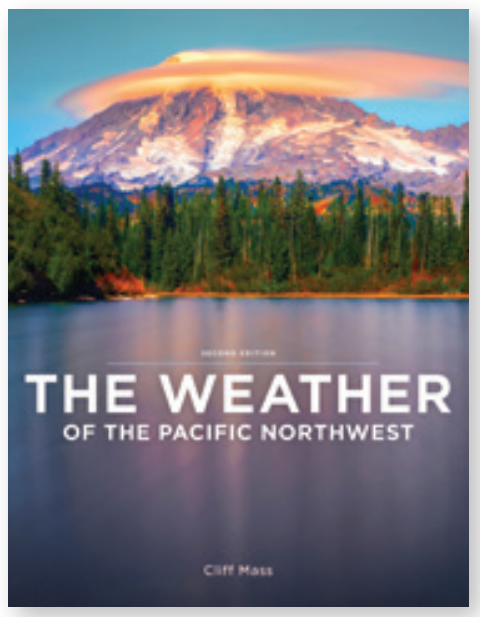

The Weather of the Pacific Northwest

SECOND EDITION

Cliff Mass

\$34.95 PB / ISBN 9780295748443

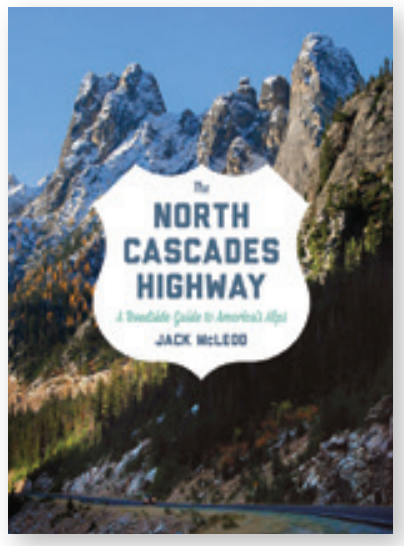

The North Cascades Highway A Roadside Guide to America's Alps Jack McLeod $\$ 26.95$ PB / ISBN 9780295993164

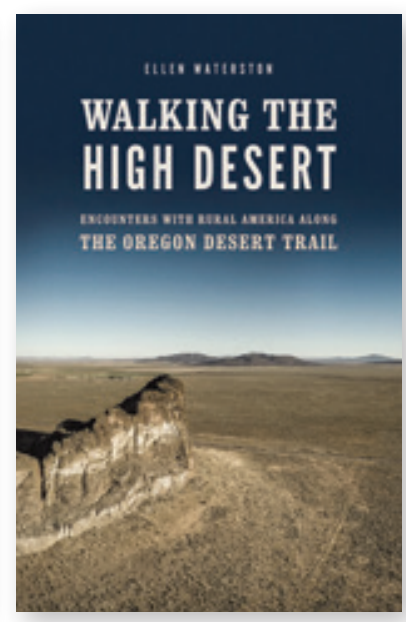

Walking the High Desert Encounters with Rural America along the Oregon Desert Trail

Ellen Waterston

$\$ 24.95$ PB / ISBN 9780295747507

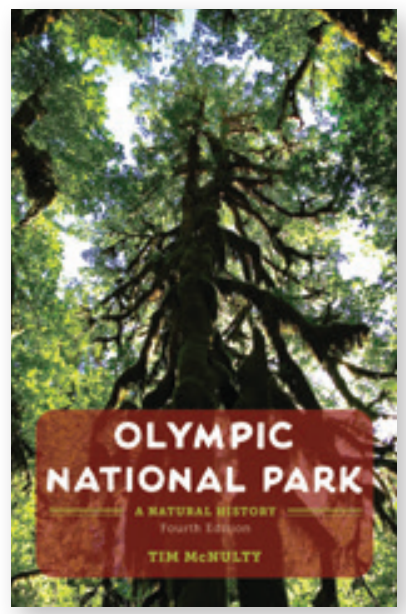

Olympic National Park

A Natural History, fourth edition Tim McNulty

$\$ 29.95$ PB / ISBN 9780295743288

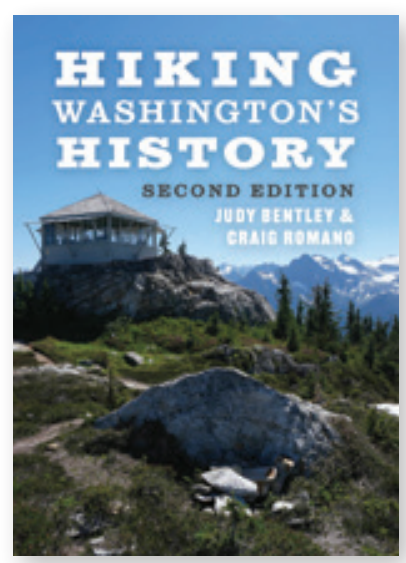

Hiking Washington's History SECOND EDITION

Judith M. Bentley and Craig Romano \$19.95 PB / ISBN 9780295748528

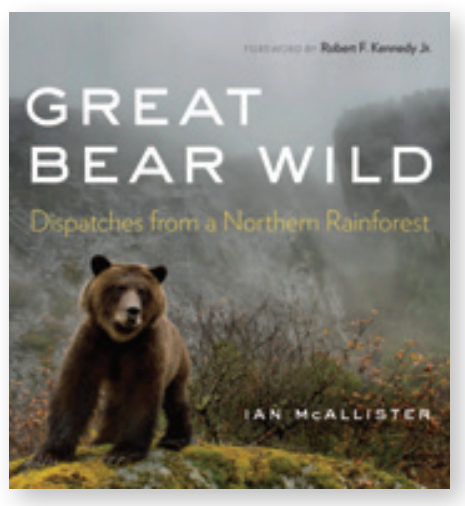

\section{Great Bear Wild}

Dispatches from a Northern Rainforest Ian McAllister

Foreword by Robert F. Kennedy Jr. \$24.95 PB / ISBN 9780295749143 

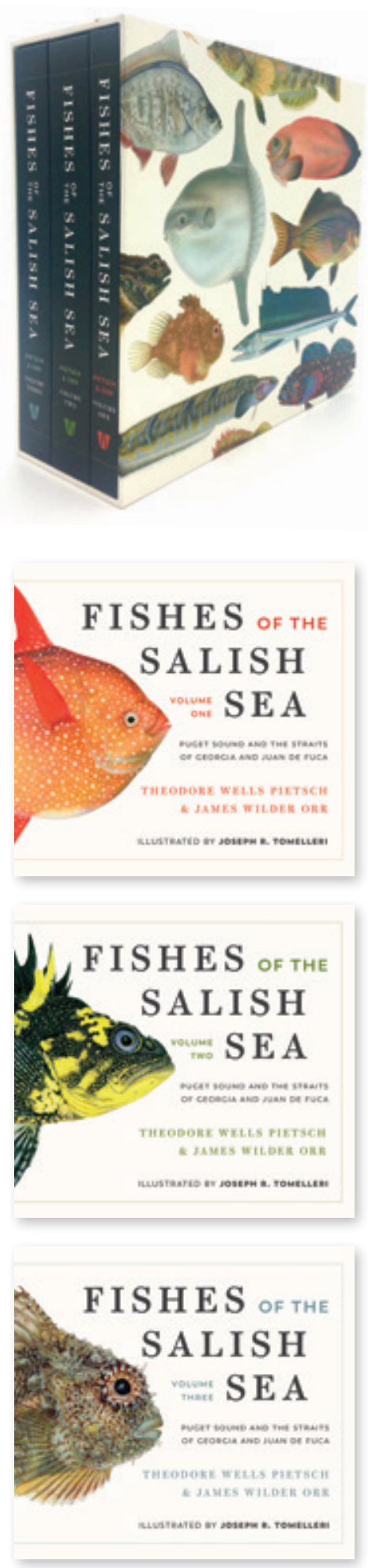

Fishes of the Salish Sea

Puget Sound and the Straits of Georgia and Juan de Fuca THREE-VOLUME BOXED SET

Theodore Wells Pietsch and James Wilder Orr Illustrated by Joseph R. Tomelleri

$\$ 150.00 \mathrm{HC} /$ ISBN 9780295743745

WINNER OF THE 2020 PROSE AWARD IN TEXTBOOK/BIOLOGICAL SCIENCE CATEGORY, SPONSORED BY THE ASSOCIATION OF AMERICAN PUBLISHERS

WINNER OF THE 2020 GOLD AWARD IN THE REFERENCE BOOK CATEGORY, SPONSORED BY THE PUBWEST ASSOCIATION

SHORTLISTED FOR THE 2020 ALICE AWARD, SPONSORED BY THE FURTHERMORE FOUNDATION

"The definitive guide to the coastal fish of Washington State and British Columbia is as lovely as it is weighty.... Luminous color illustrations of each fish set against a white background make this a work of art, as well as an unmatched scientific reference."

-Natural History Magazine

"This monumental effort represents many years of work, tremendous attention to detail, and an obvious love for the subject."

\section{-Quarterly Review of Biology}

"Stunning, lavish, comprehensive, and accurate: these four words epitomize Pietsch and Orr's (2019) new magnum opus on the diversity, identification, ecology, and distribution of the 260 fish species that inhabit the Pacific Northwest's Salish Sea."

-Northwestern Naturalist 


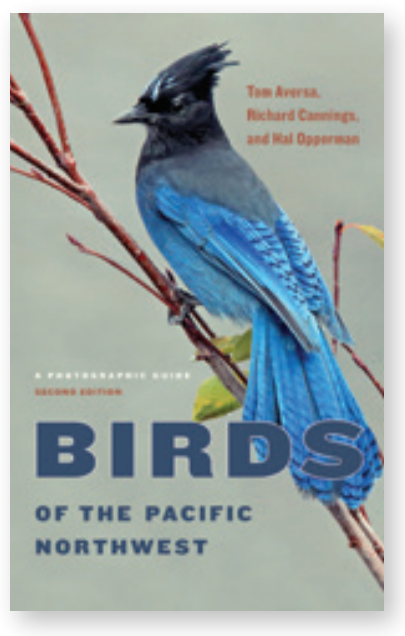

Birds of the Pacific Northwest A Photographic Guide SECOND EDITION Tom Aversa, Richard Cannings, and Hal Opperman \$29.95 PB / ISBN 9780295748054

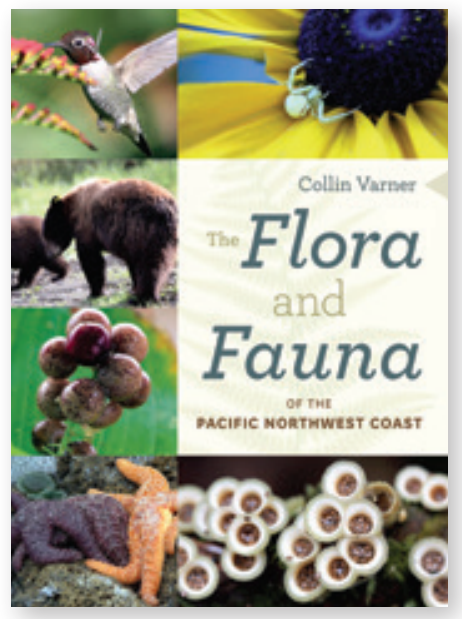

The Flora and Fauna of the Pacific Northwest Coast

Collin Varner

\$34.95 PB / ISBN 9780295744643

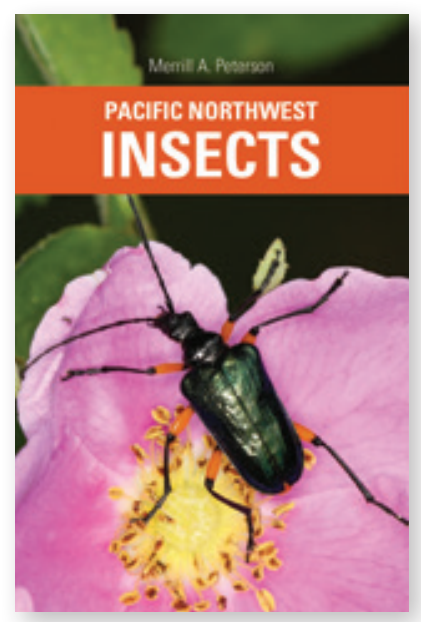

Pacific Northwest Insects

Merrill A. Peterson

\$34.95 PB / ISBN 9780914516187

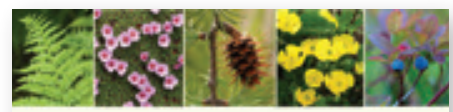

GARDENING

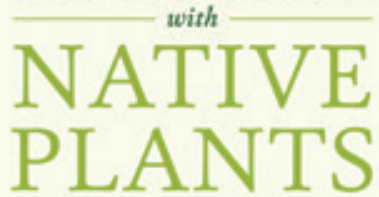

OF THE PACIFIC NORTHWEST

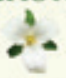

ARTHUR R. KRUCKEBERG AND LINDA CHALKER-SCOTT

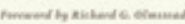

Gardening with Native Plants of the Pacific Northwest THIRD EDITION

Arthur R. Kruckeberg and Linda Chalker-Scott

\$39.95 PB / ISBN 9780295744155

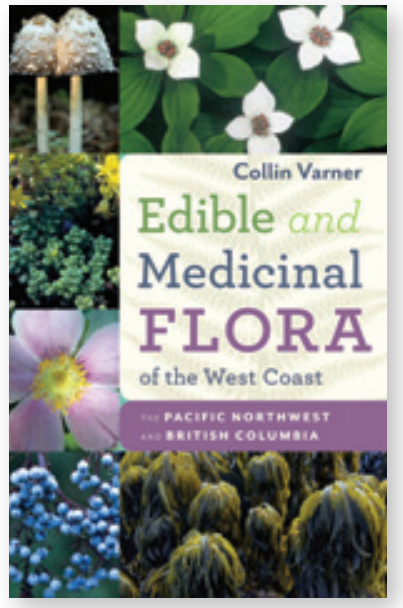

Edible and Medicinal Flora of the West Coast

The Pacific Northwest and British

Columbia

Collin Varner

\$19.95 PB / ISBN 9780295748047

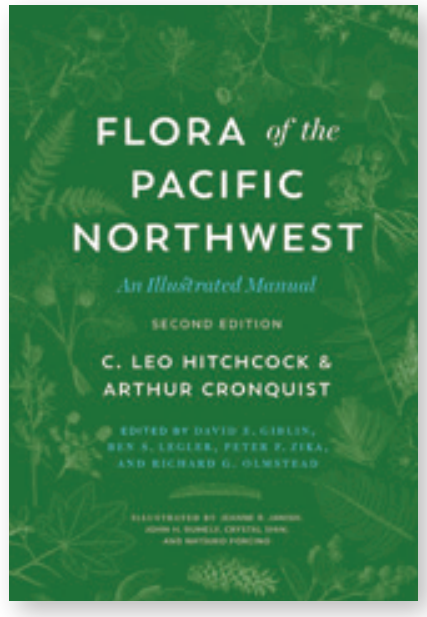

Flora of the Pacific Northwest An Illustrated Manual SECOND EDITION

C. Leo Hitchcock and Arthur Cronquist Edited by David E. Giblin, Ben S. Legler, Peter F. Zika, and Richard G. Olmstead $\$ 75.00$ s HC / ISBN 9780295742885 


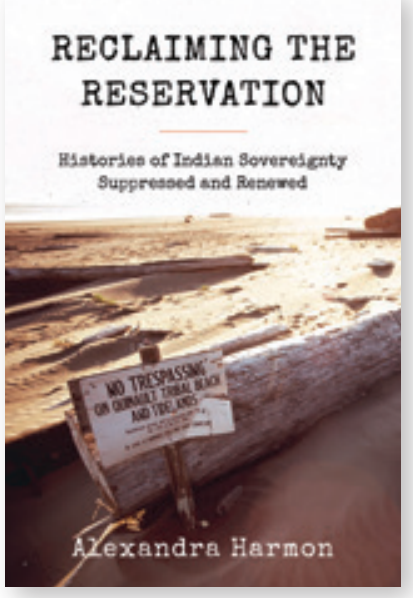

Reclaiming the Reservation Histories of Indian Sovereignty Suppressed and Renewed Alexandra Harmon $\$ 35.00$ S PB / ISBN 9780295745855

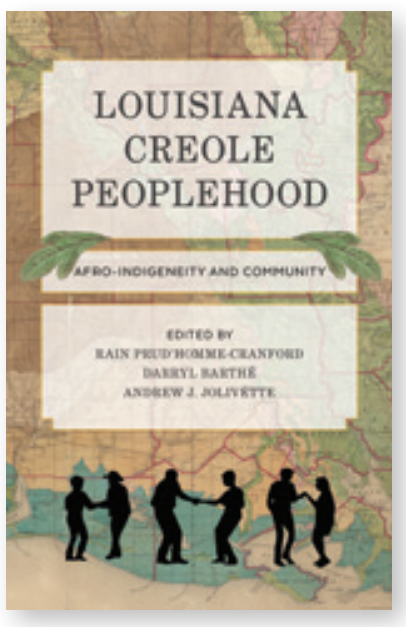

Louisiana Creole Peoplehood Afro-Indigeneity and Community Edited by Rain Prud'homme-Cranford, Darryl Barthé, and Andrew J. Jolivétte \$30.00S PB / ISBN 9780295749495

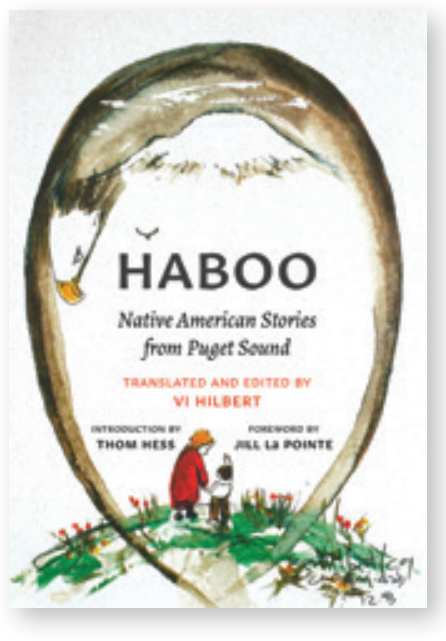

\section{Haboo}

Native American Stories from

Puget Sound

SECOND EDITION

Vi Hilbert

Introduction by Thom Hess

Foreword by Jill La Pointe

\$29.95 PB / ISBN 9780295746968

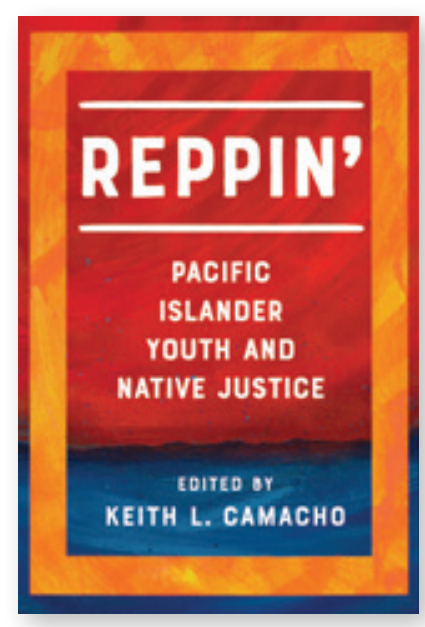

Reppin'

Pacific Islander Youth and

Native Justice

Edited by Keith L. Camacho

$\$ 30.00$ S PB / ISBN 9780295748580

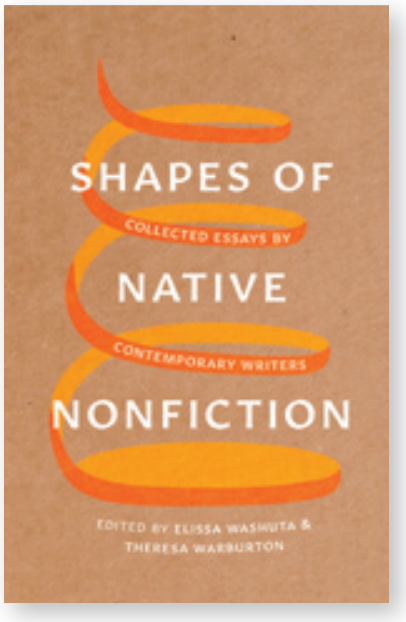

Shapes of Native Nonfiction

Collected Essays by Contemporary Writers

Edited by Elissa Washuta and Theresa Warburton \$29.95 PB / ISBN 9780295745756 


\section{INDIGENOUS CONFLUENCES}

\section{Charlotte Coté and Coll Thrush, series editors}

Indigenous Confluences publishes innovative works that use decolonizing perspectives and transnational approaches to explore the experiences of Indigenous peoples across North America, with a special emphasis on the Pacific coast.

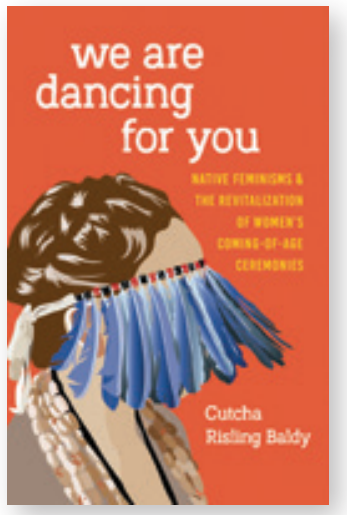

We Are Dancing for You

Native Feminisms and the Revitalization of Women's Coming-of-Age Ceremonies

Cutcha Risling Baldy

$\$ 30.00$ S PB / ISBN 9780295743448

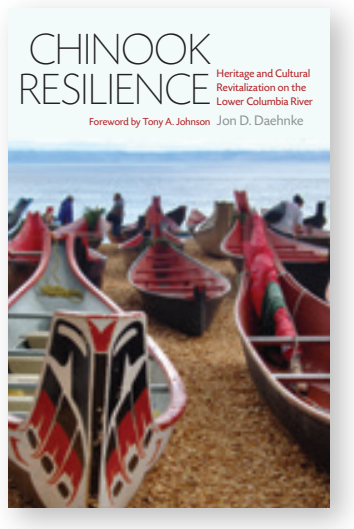

\section{Chinook Resilience}

Heritage and Cultural Revitalization on the Lower Columbia River Jon D. Daehnke Foreword by Tony A. Johnson $\$ 30.00$ S PB / ISBN 9780295742267

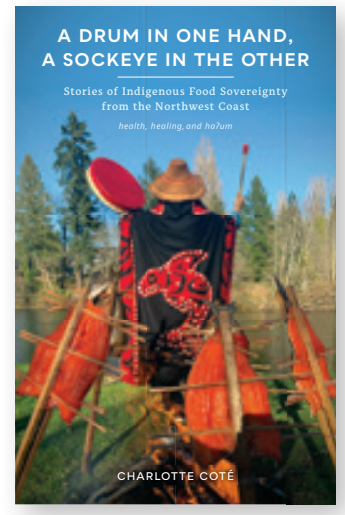

A Drum in One Hand, a Sockeye in the Other Stories of Indigenous Food Sovereignty from the Northwest Coast Charlotte Coté \$29.95 PB / ISBN 9780295749525

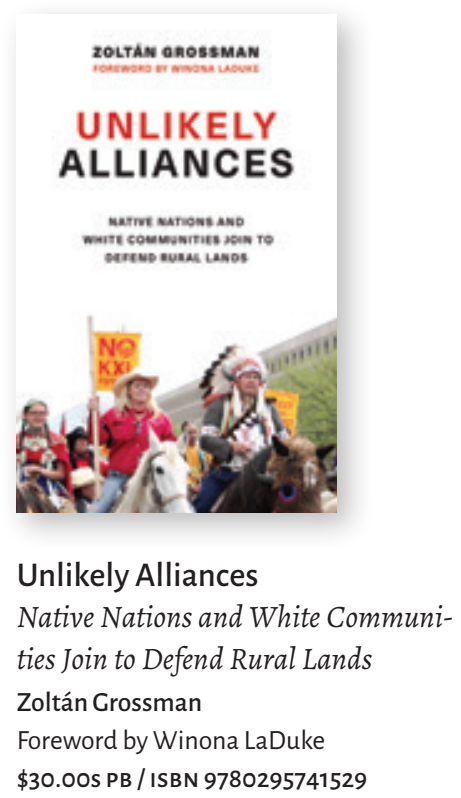

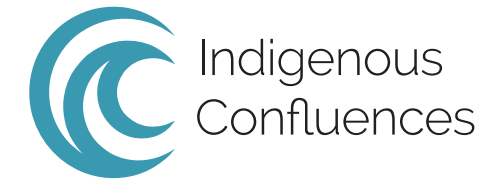

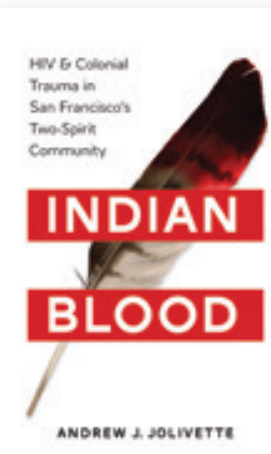

Indian Blood

HIV and Colonial Trauma in

San Francisco's Two-Spirit

Community

Andrew J. Jolivette

\$30.00S PB / ISBN 9780295998503

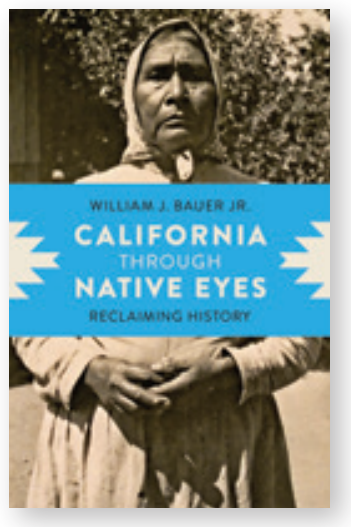

California through Native Eyes

Reclaiming History

William J. Bauer ]r.

$\$ 30.00$ S PB / ISBN 9780295998350 


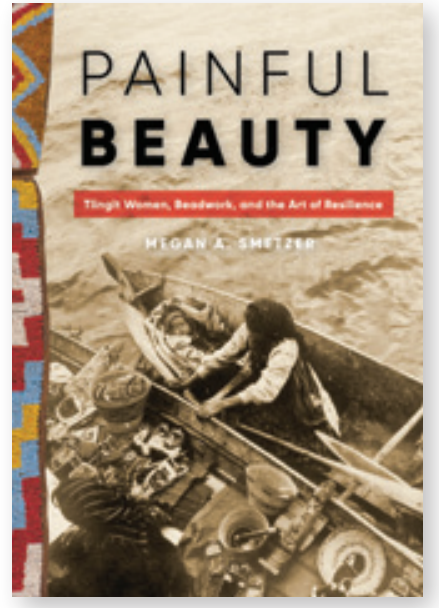

Painful Beauty

Tlingit Women, Beadwork, and the Art of Resilience

Megan A. Smetzer

$\$ 39.95$ HC / ISBN 9780295748948

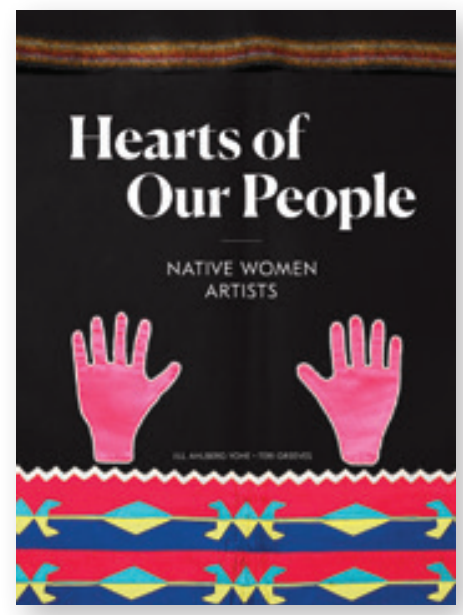

Hearts of Our People

Native Women Artists

Edited by Jill Ahlberg Yohe

and Teri Greeves

$\$ 39.95$ PB / ISBN 9780295745794

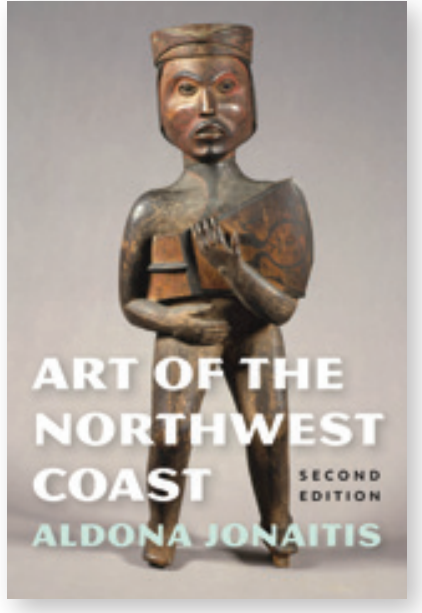

Art of the Northwest Coast SECOND EDITION

Aldona Jonaitis

\$29.95 PB / ISBN 9780295748559

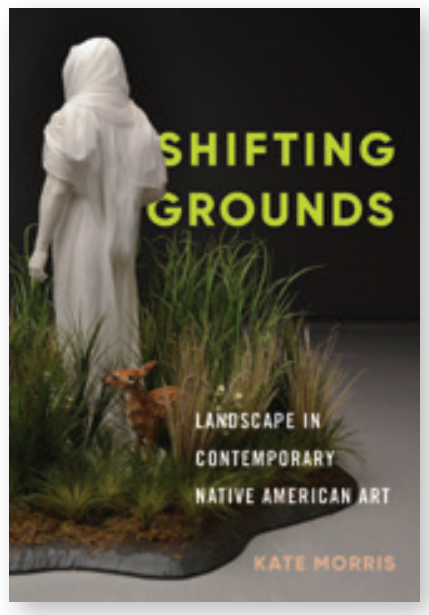

Shifting Grounds

Landscape in Contemporary

Native American Art

Kate Morris

$\$ 35.00$ S PB / 9780295749167

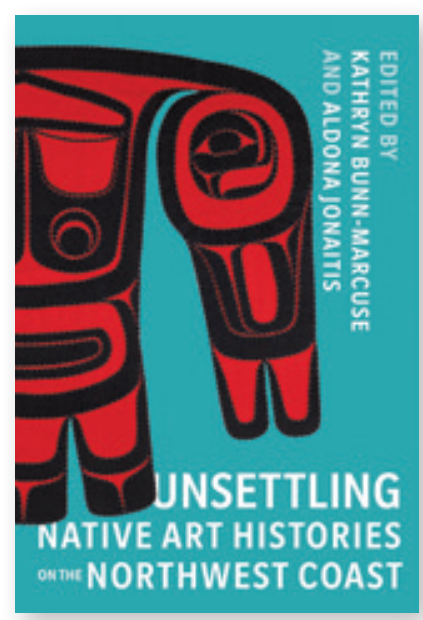

Unsettling Native Art Histories on the Northwest Coast

Edited by Kathryn Bunn-Marcuse and Aldona Jonaitis

$\$ 39.95$ HC/ ISBN 9780295747132
Becoming Mary Sully

Toward an American Indian Abstract Philip J. Deloria

\$34.95 PB / ISBN 9780295745046 


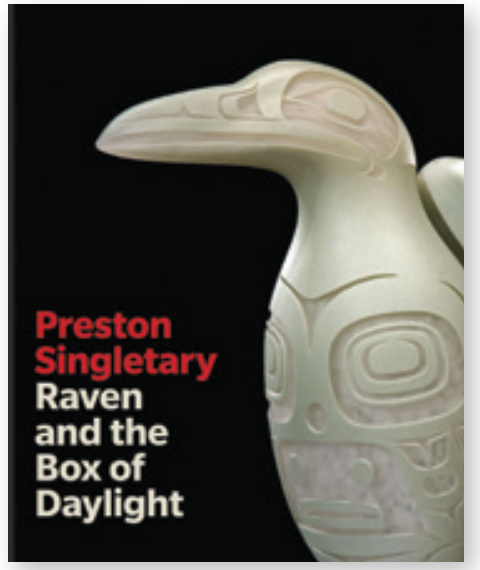

Preston Singletary

Raven and the Box of Daylight

Miranda Belarde-Lewis and John Drury. $\$ 50.00 \mathrm{HC} /$ ISBN 9780972664950

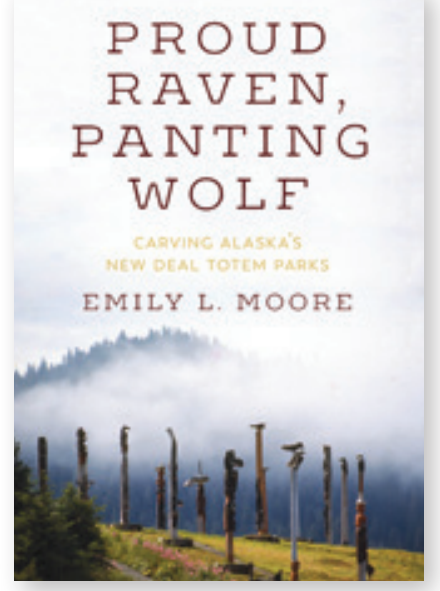

\section{Proud Raven, Panting Wolf}

Carving Alaska's New Deal Totem Parks

Emily L. Moore

\$29.95 PB / ISBN 9780295747552

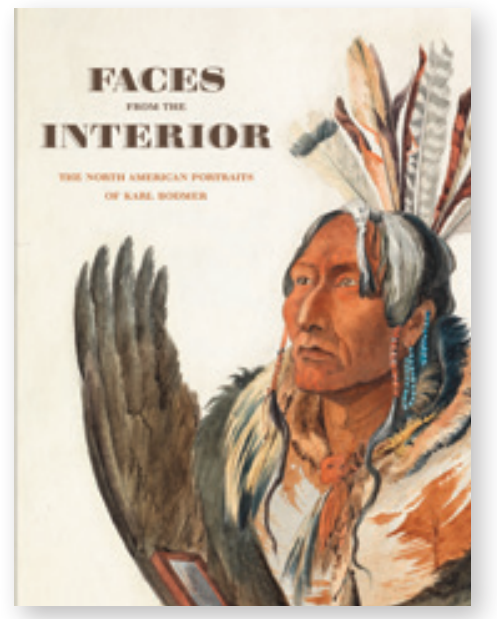

\section{Faces from the Interior}

The North American Portraits of Karl Bodmer

Toby Jurovics, Scott Manning Stevens, Lisa Strong, Kristine K. Ronan, and Annika K. Johnson $\$ 44.95$ HC / ISBN 9781735441641

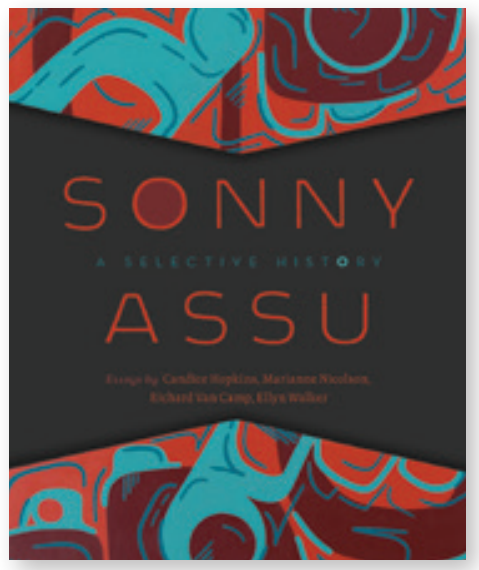

\section{Sonny Assu}

A Selective History

Sonny Assu

With Candice Hopkins, Marianne Nicolson, Richard Van Camp, and Ellyn Walker $\$ 34.95$ PB / ISBN 9780295742113

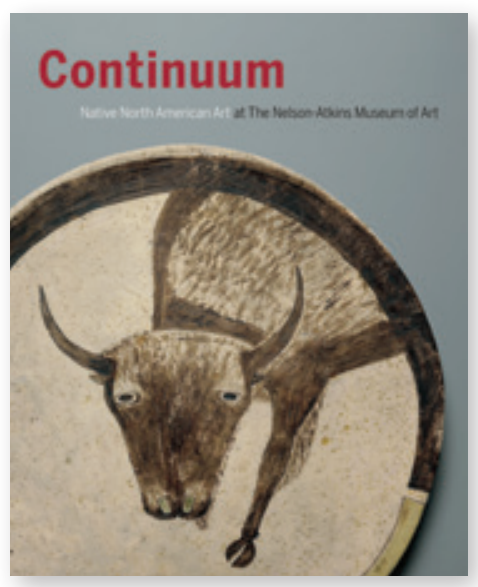

\section{Continuum}

Native North American Art at the Nelson-Atkins Museum of Art Edited by Gaylord Torrence With W. Richard West Jr. and Stephanie Fox Knappe $\$ 46.00 \mathrm{HC} /$ ISBN 9780997044652 


\section{DECOLONIZING FEMINISMS}

\section{Piya Chatterjee, series editor}

Decolonizing Feminisms explores the integral connections between theory, activism, policy making, and other forms of social action. The series brings together new work by US women of color, Indigenous, and transnational feminists to envision critical and imaginative frameworks for political resistance and progressive social change.

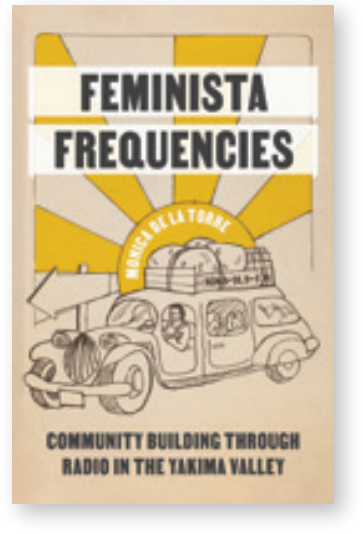

\section{Feminista Frequencies}

Community Building through Radio in the Yakima Valley

Monica De La Torre

\$27.95 PB / ISBN 9780295749662

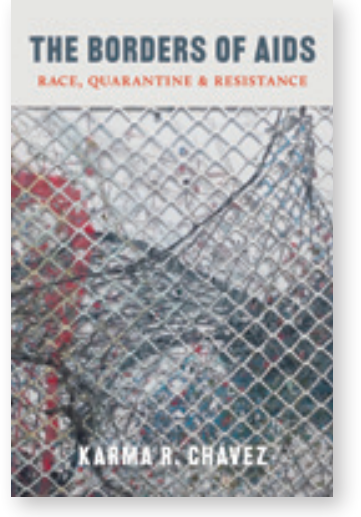

\section{The Borders of AIDS}

Race, Quarantine, and Resistance Karma R. Chávez

\$25.00S PB 9780295748979

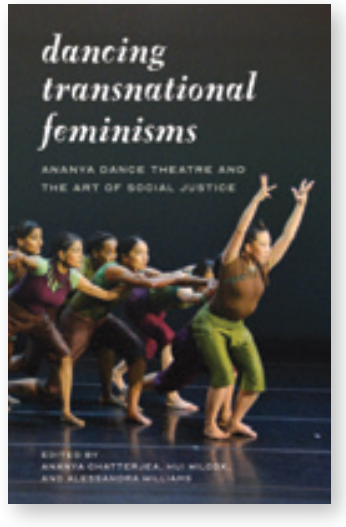

\section{Dancing Transnational Feminisms}

Ananya Dance Theatre and the Art of Social Justice

Edited by Ananya Chatterjea, Hui Niu Wilcox, and Alessandra Lebea Williams Foreword by D. Soyini Madison \$30.00S PB / ISBN 9780295749556

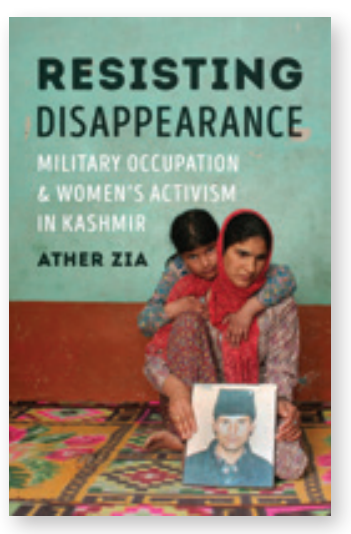

\section{Resisting Disappearance}

Military Occupation and Women's

Activism in Kashmir

Ather Zia

\$30.00s PB / ISBN 9780295744988

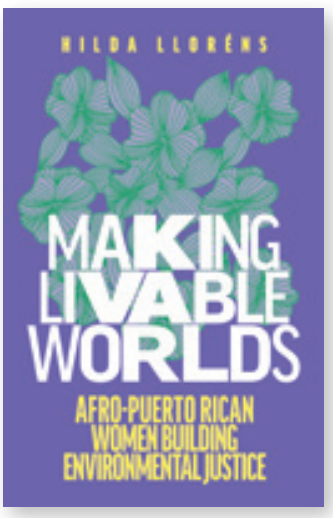

Making Livable Worlds Afro-Puerto Rican Women Building Environmental Justice Hilda Lloréns \$30.00S PB / ISBN 9780295749402

\section{Axis of Hope Iranian Women's Rights Activism across Borders Catherine Z. Sameh \$30.0OS PB / ISBN 9780295746326}

\section{Tea and Solidarity} Tamil Women and Work in Postwar Sri Lanka Mythri Jegathesan \$30.00S PB / ISBN 9780295745671

\section{Unruly Figures}

Queerness, Sex Work, and the Politics of Sexuality in Kerala Navaneetha Mokkil \$30.0OS PB / ISBN 9780295745572 


\section{FEMINIST TECHNOSCIENCES}

\section{Rebecca Herzig and Banu Subramaniam, series editors}

Feminist Technosciences publishes emerging, intersectional, cutting-edge feminist work. The series foregrounds insights from queer studies, critical race studies, disability studies, animal studies, postcolonial theory, and other critical approaches that reframe and reignite long-standing questions in feminist science and technology studies.

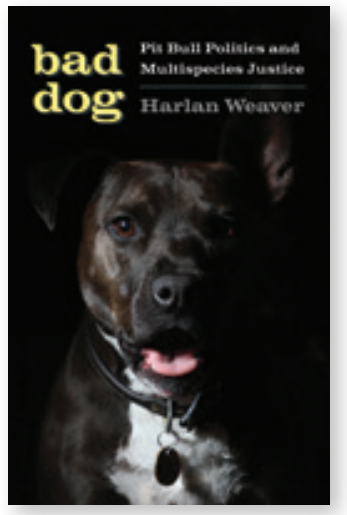

\section{Bad Dog}

Pit Bull Politics and Multispecies Justice

Harlan Weaver

\$30.00S PB / ISBN 9780295748023

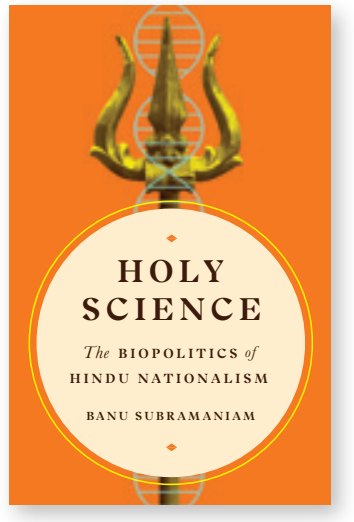

\section{Holy Science}

The Biopolitics of Hindu Nationalism Banu Subramaniam $\$ 30.00$ S PB / ISBN 9780295745596

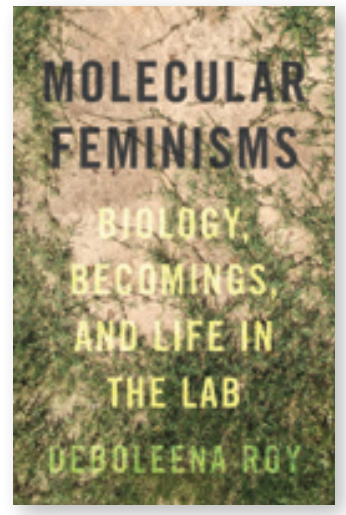

\section{Molecular Feminisms}

Biology, Becomings, and Life in the Lab Deboleena Roy

$\$ 30.00$ S PB / ISBN 9780295744100

TOME OA EDITION / DOI 10.6069/J163-3C90

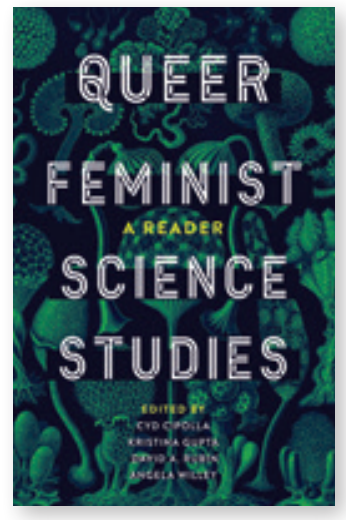

Queer Feminist Science Studies A Reader

Edited by Cyd Cipolla, Kristina Cupta, David A. Rubin, and Angela Willey $\$ 30.00$ S PB / ISBN 9780295742588

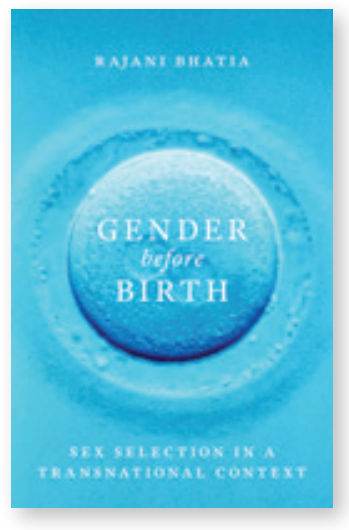

\section{Gender before Birth}

Sex Selection in a

Transnational Context

Rajani Bhatia

\$30.00S PB / ISBN 9780295999210

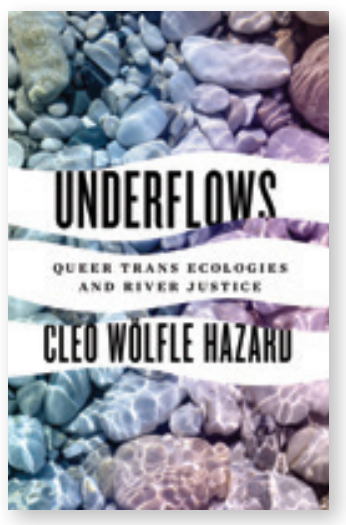

\section{Underflows}

Queer Trans Ecologies and River Justice Cleo Wölfle Hazard

$\$ 30.00$ S PB / ISBN 9780295749754 


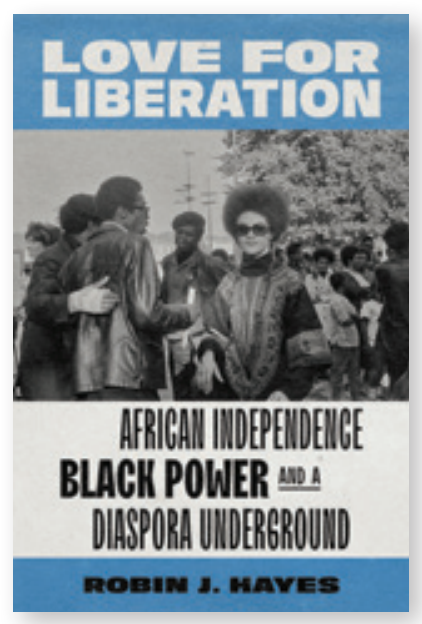

Love for Liberation

African Independence, Black Power, and a Diaspora Underground

Robin J. Hayes

$\$ 30.00$ S PB / ISBN 9780295749075

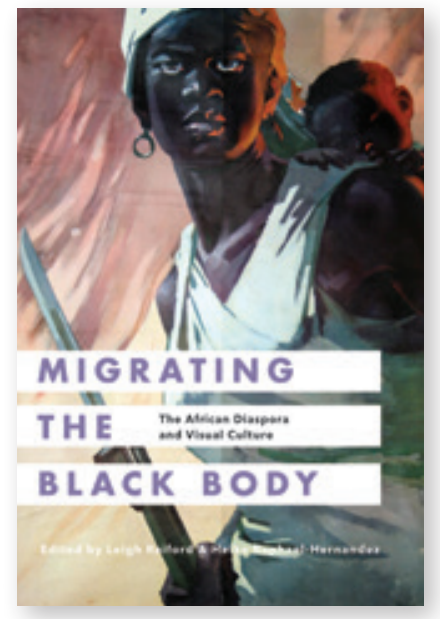

Migrating the Black Body

The African Diaspora and Visual Culture

Edited by Leigh Raiford and Heike Raphael-Hernandez

$\$ 30.00$ S PB / ISBN 9780295999579

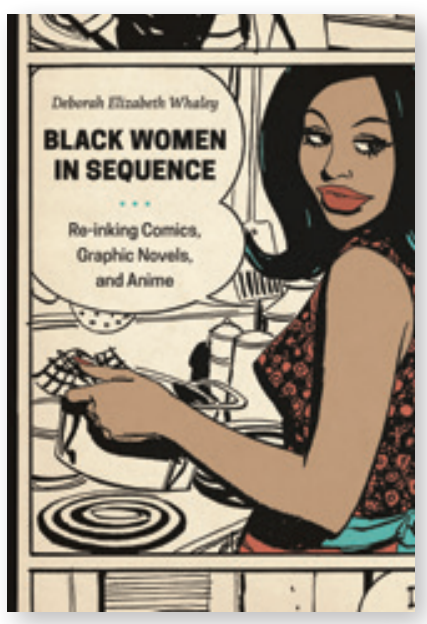

Black Women in Sequence

Re-inking Comics, Graphic Novels, and Anime

Deborah Elizabeth Whaley $\$ 30.00$ S PB / ISBN 9780295994963

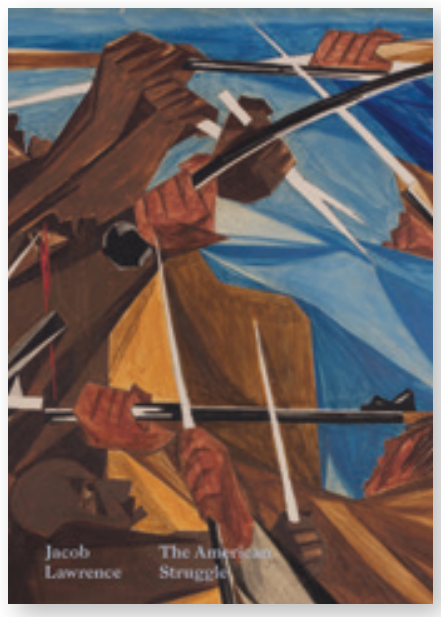

\section{Jacob Lawrence}

The American Struggle

Edited by Elizabeth Hutton Turner and Austen Barron Bailly $\$ 45.00$ HC / ISBN 9780295747040

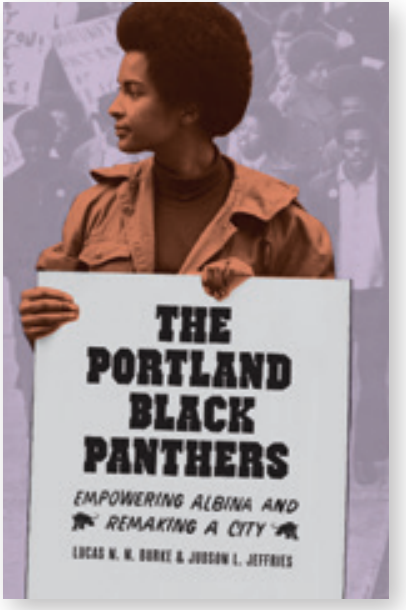

The Portland Black Panthers Empowering Albina and Remaking a City

Lucas N. N. Burke and Judson L. Jeffries \$24.95 PB / ISBN 9780295742717

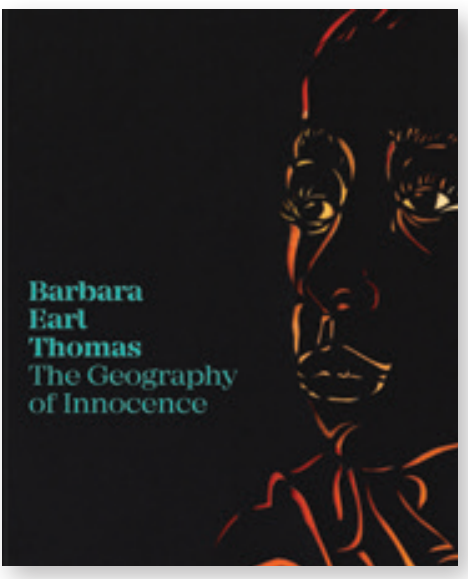

\section{Barbara Earl Thomas}

The Geography of Innocence

Catharina Manchanda, Halima Taha, and Barbara Earl Thomas \$24.95 PB / ISBN 9780932216786 


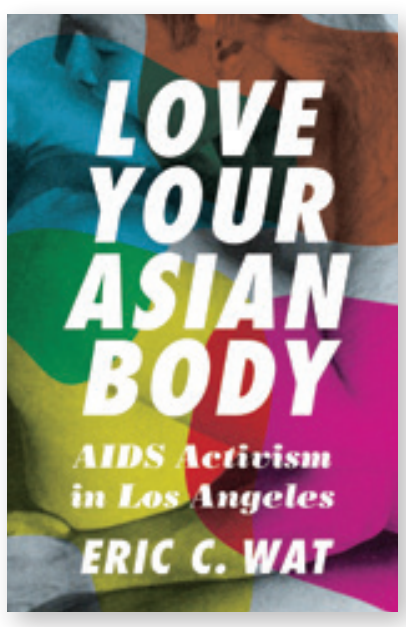

Love Your Asian Body

AIDS Activism in Los Angeles

Eric C. Wat

\$29.95 PB / ISBN 9780295749334

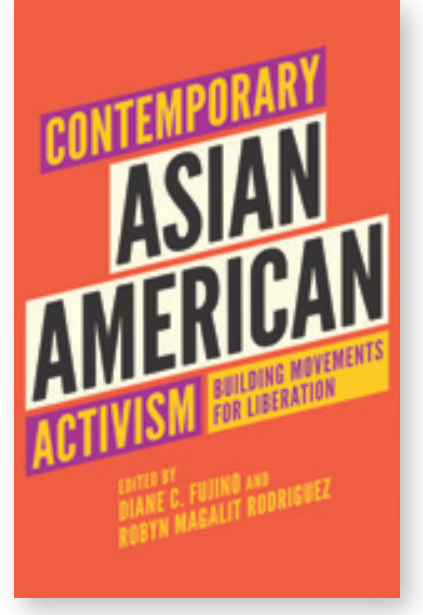

Contemporary Asian American Activism

Building Movements for Liberation Edited by Diane C. Fujino and Robyn Magalit Rodriguez $\$ 30.00$ S PB / ISBN 9780295749808

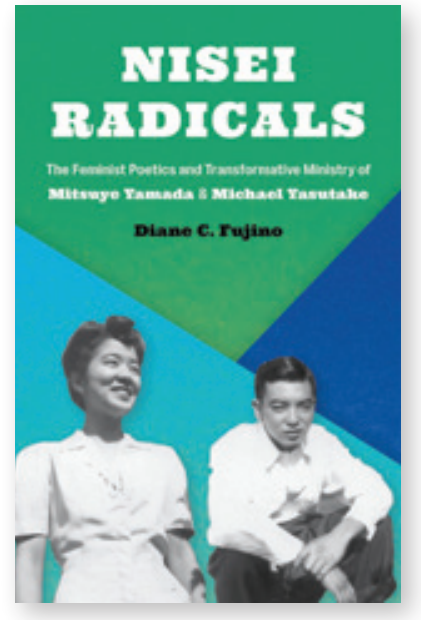

\section{Nisei Radicals}

The Feminist Poetics and Transformative Ministry of Mitsuye Yamada and Michael Yasutake

Diane C. Fujino

$\$ 29.95$ PB / ISBN 9780295748269

\section{ASIAN}

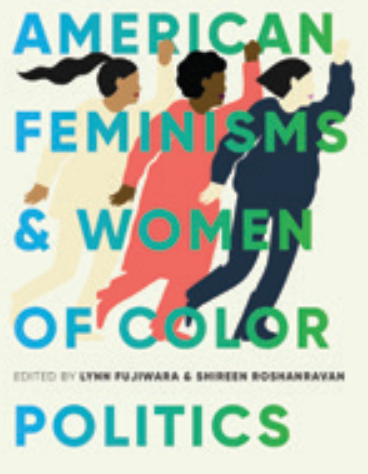

Asian American Feminisms and Women of Color Politics

Edited by Lynn Fujiwara and Shireen

Roshanravan

\$30.00S PB / ISBN 9780295744353

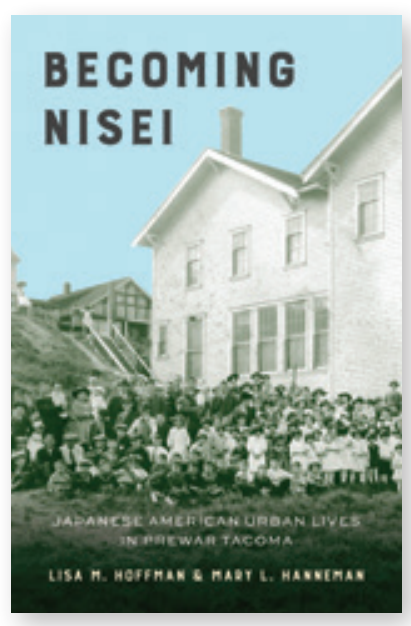

Becoming Nisei

Japanese American Urban Lives in Prewar Tacoma

Lisa M. Hoffman and Mary L. Hanneman $\$ 29.95$ PB / ISBN 9780295748221 


\section{CLASSICS OF ASIAN AMERICAN LITERATURE}

For more than four decades, the University of Washington Press has published foundational works in Asian American literature. Thanks to Shawn Wong and other authors and advisers, the press has been able to bring back into print more than a dozen books, reintroducing important and classic works for a new generation of readers.

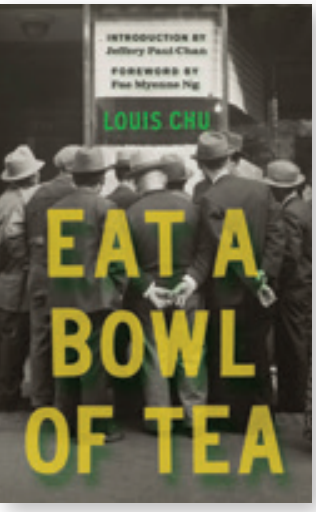

\section{Eat a Bowl of Tea}

Louis Chu

Foreword by Fae Myenne Ng Introduction by Jeffery Paul Chan \$22.95 PB / ISBN 9780295747057

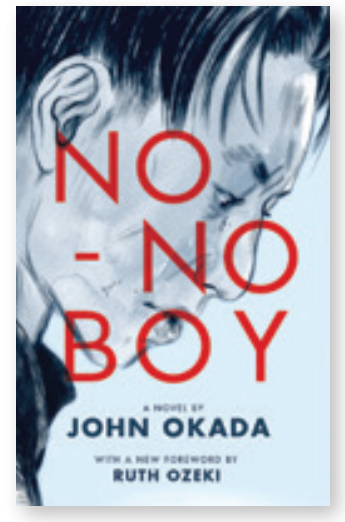

\section{No-No Boy}

John Okada

Foreword by Ruth Ozeki

Introduction by Lawson Fusao Inada and Frank Chin

$\$ 17.95$ PB / ISBN 9780295994048

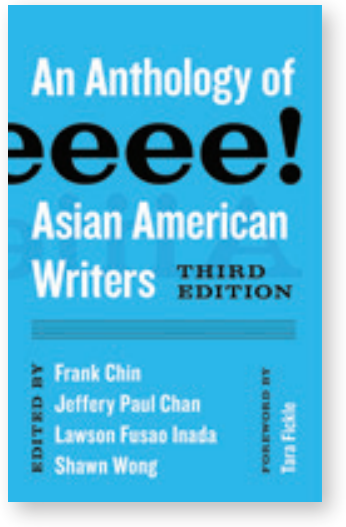

\section{Aiiieeeee!}

An Anthology of Asian American Writers THIRD EDITION

Edited by Frank Chin, Jeffery Paul Chan, Lawson Fusao Inada, and Shawn Wong Foreword by Tara Fickle

\$24.95 PB / ISBN 9780295746487

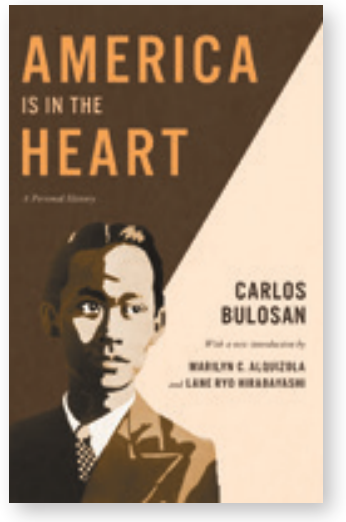

\section{America Is in the Heart}

A Personal History

\section{REVISED EDITION}

Carlos Bulosan

Introduction by Marilyn C. Alquizola and Lane Ryo Hirabayashi

\$17.95 PB / ISBN 9780295993539

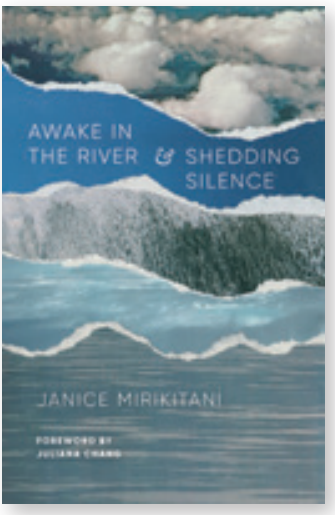

Awake in the River and Shedding Silence

Janice Mirikitani

Foreword by Juliana Chang

\$24.95 PB / ISBN 9780295749587

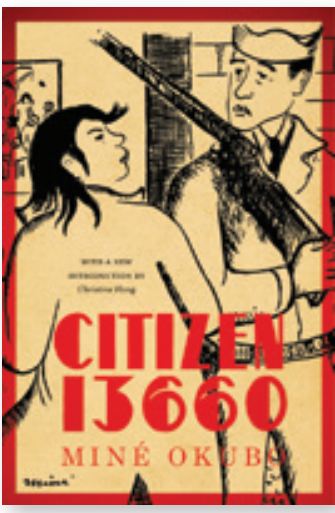

\section{Citizen 13660}

REVISED EDITION

Miné Okubo

Introduction by Christine Hong $\$ 19.95$ PB / ISBN 9780295993546 


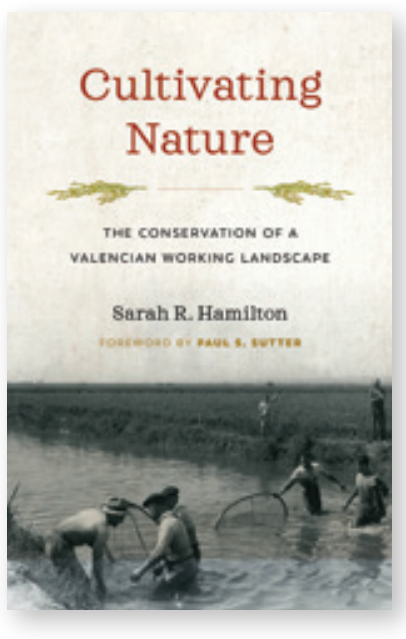

\section{Cultivating Nature}

The Conservation of a Valencian

Working Landscape

Sarah R. Hamilton

Foreword by Paul S. Sutter

$\$ 30.00$ S PB / ISBN 9780295748092

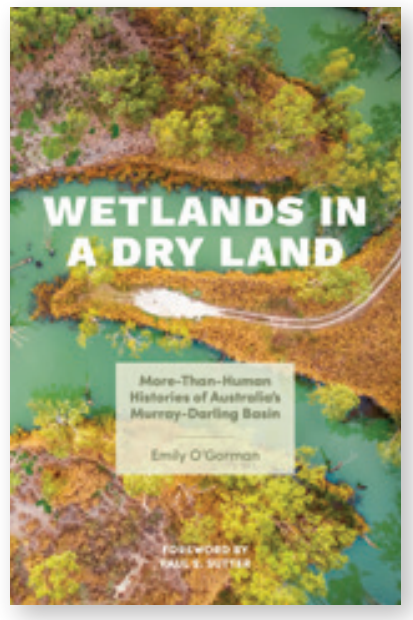

Wetlands in a Dry Land

More-Than-Human Histories of

Australia's Murray-Darling Basin

Emily O'Corman

Foreword by Paul S. Sutter

$\$ 30.00$ S PB / ISBN 9780295749150

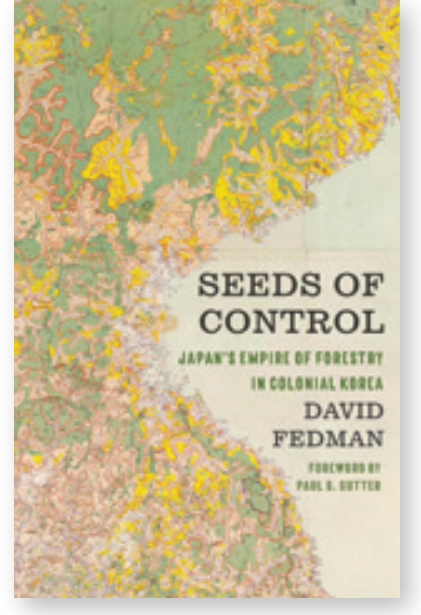

\section{Seeds of Control}

Japan's Empire of Forestry in

Colonial Korea

David Fedman

Foreword by Paul S. Sutter

$\$ 40.00$ S HC / ISBN 9780295747453

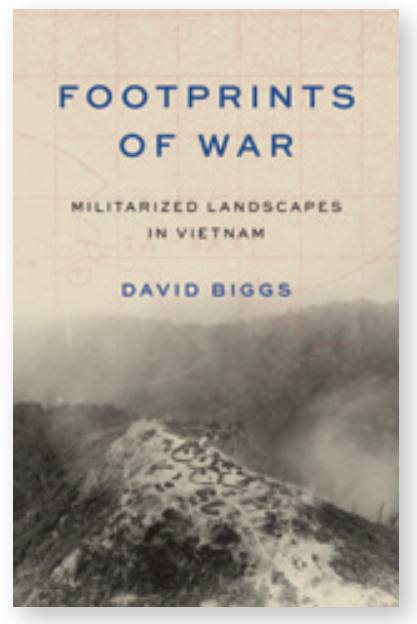

\section{Footprints of War}

Militarized Landscapes in Vietnam David Biggs

Foreword by Paul S. Sutter

$\$ 30.00$ S PB / ISBN 9780295749730

OA EDITION / DOI 10.6069/9780295743875

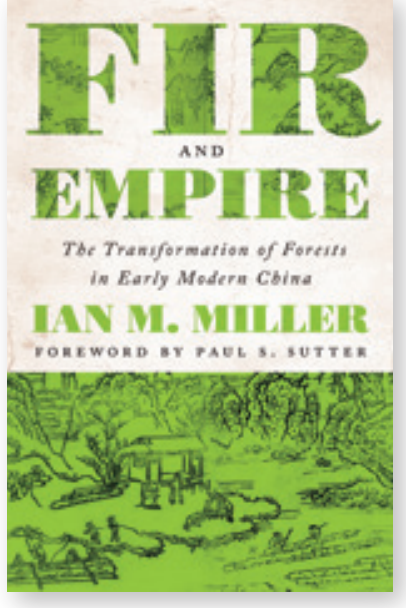

\section{Fir and Empire}

The Transformation of Forests in Early Modern China

lan M. Miller

Foreword by Paul S. Sutter

$\$ 40.00$ S HC / ISBN 9780295747330

OA EDITION / DOI 10.6069/9780295747347

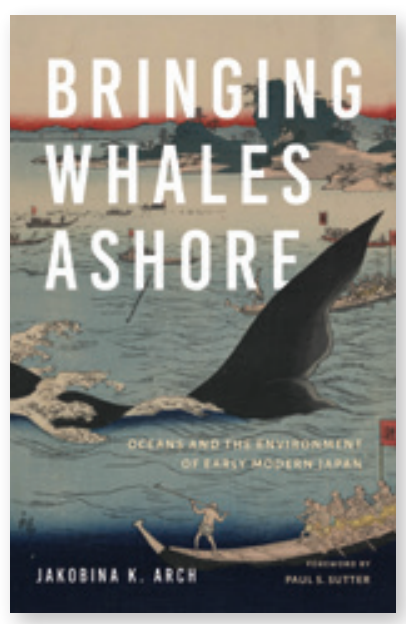

Bringing Whales Ashore

Oceans and the Environment of Early Modern Japan

Jakobina K. Arch

Foreword by Paul S. Sutter $\$ 30.00$ S PB / ISBN 9780295748108 


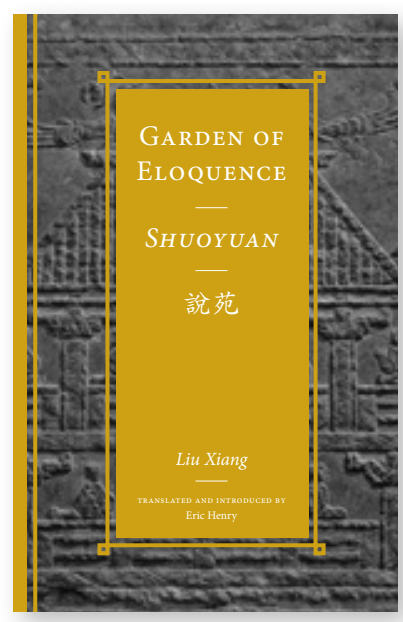

Garden of Eloquence / Shuoyuan Liu Xiang

Translated and Introduced by Eric Henry $\$ 125.00$ S HC / ISBN 9780295995199

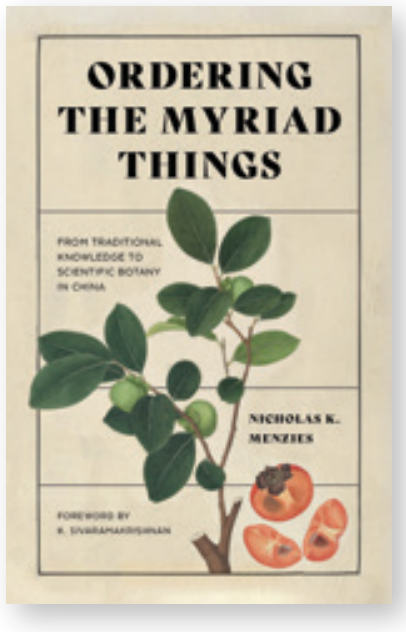

Ordering the Myriad Things From Traditional Knowledge to Scientific Botany in China Nicholas K. Menzies Foreword by K. Sivaramakrishnan \$30.00S PB / ISBN 9780295749464

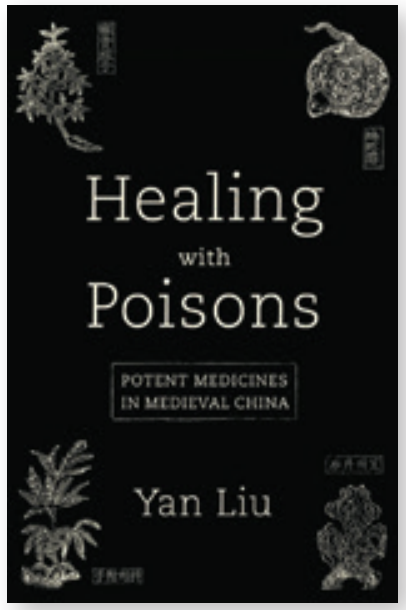

\section{Healing with Poisons}

Potent Medicines in Medieval China Yan Liu

$\$ 30.00$ S PB / ISBN 9780295748993

TOME OA EDITION / DOI

$10.6069 / 9780295749013$

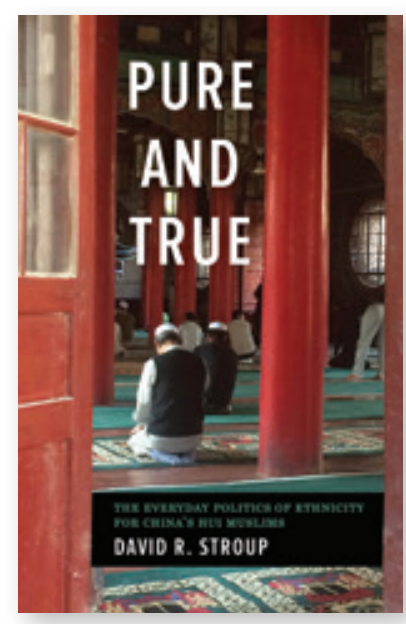

\section{Pure and True}

The Everyday Politics of Ethnicity for China's Hui Muslims

David R. Stroup

$\$ 30.00$ S PB / ISBN 9780295749839

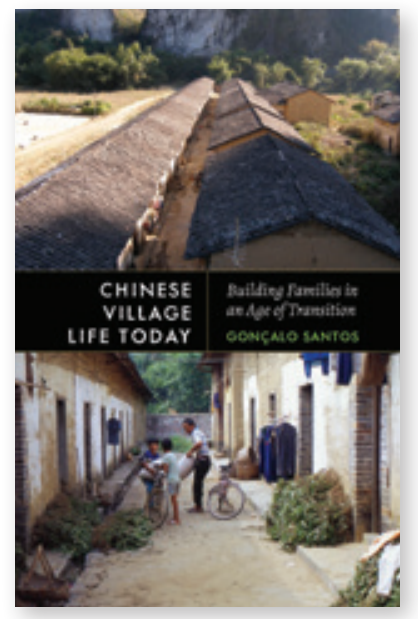

Chinese Village Life Today Building Families in an Age of Transition

Gonçalo Santos

$\$ 30.00$ S PB / ISBN 9780295747408

Durrant, Wai-yee Li, and David Schaberg \$30.00S PB / ISBN 9780295747750 


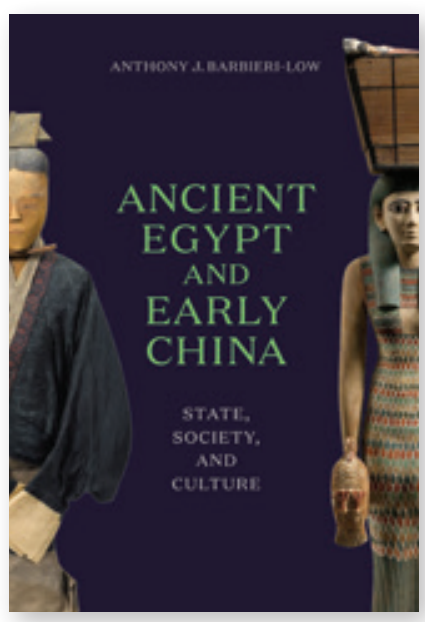

Ancient Egypt and Early China State, Society, and Culture Anthony J. Barbieri-Low $\$ 50.00$ S HC / ISBN 9780295748894

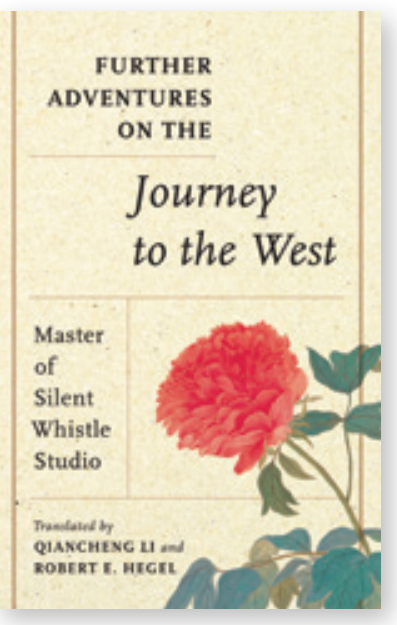

Further Adventures on the Journey to the West Master of Silent Whistle Studio Translated by Qiancheng Li and Robert E. Hegel Introduction by Qiancheng Li \$30.00S PB / ISBN 9780295747729

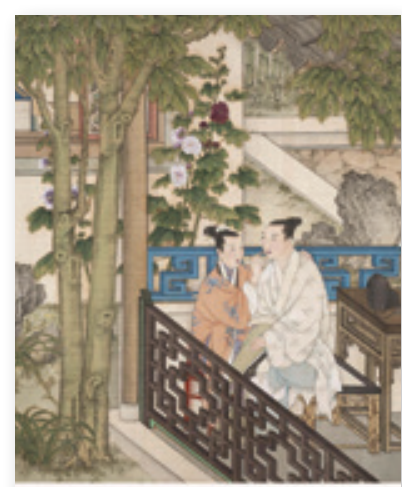

THE EMPRESS IN THE PEPPER CHAMBER

The Empress in the Pepper Chamber

Zhao Feiyan in History and Fiction Olivia Milburn

$\$ 30.00$ S PB / ISBN 9780295748757

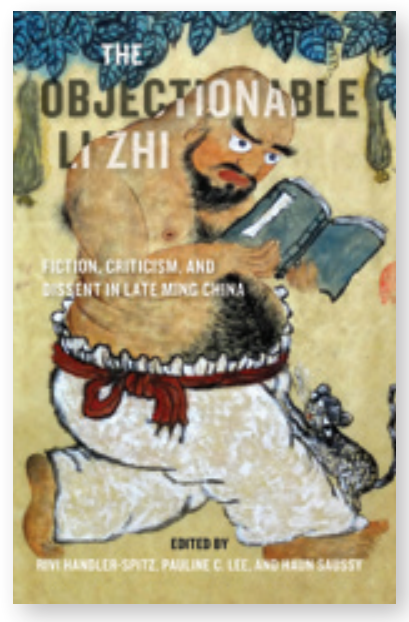

\section{The Objectionable Li Zhi}

Fiction, Criticism, and Dissent in Late Ming China

Edited by Rivi Handler-Spitz, Pauline C. Lee, and Haun Saussy $\$ 30.00$ S PB / ISBN 9780295748382 OA EDITION / DOI 10.6069/9780295748399

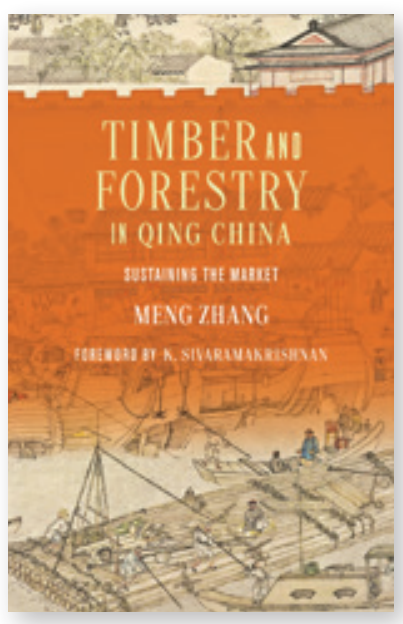

Timber and Forestry in Qing China

Sustaining the Market

Meng Zhang

Foreword by K. Sivaramakrishnan \$30.00S PB / ISBN 9780295748870

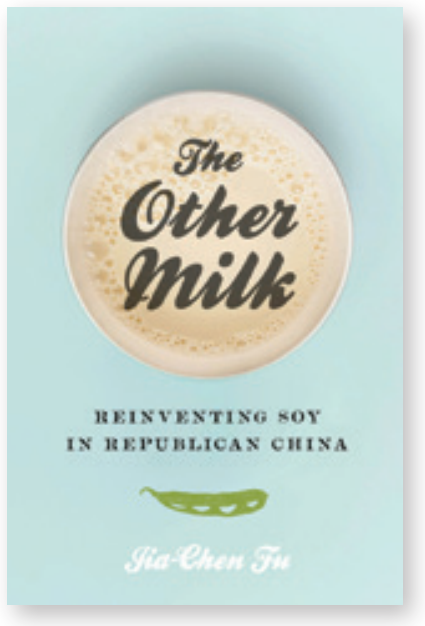

\section{The Other Milk}

Reinventing Soy in Republican China Jia-Chen $\mathrm{Fu}$

\$30.00S PB / ISBN 9780295744032 


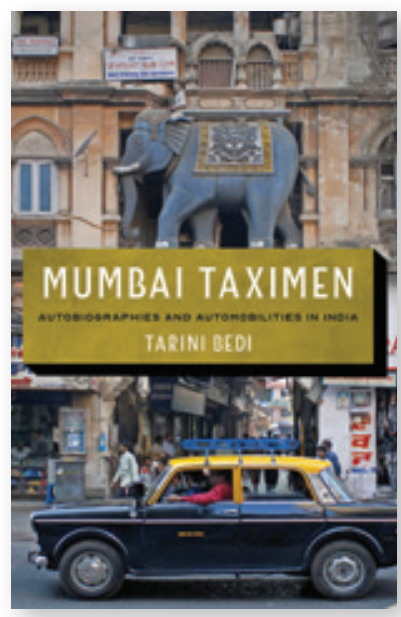

\section{Mumbai Taximen}

Autobiographies and Automobilities in India

Tarini Bedi

$\$ 30.00$ S PB / ISBN 9780295749860

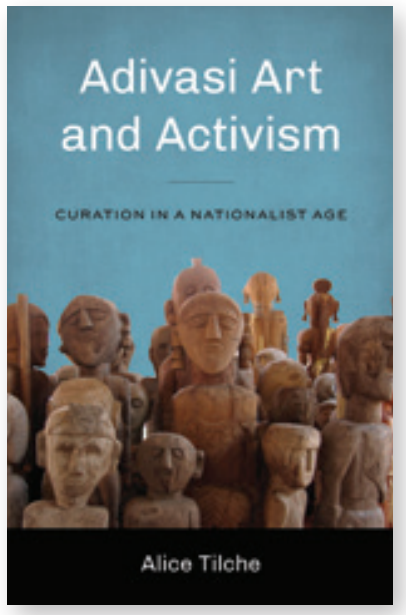

\section{Adivasi Art and Activism}

Curation in a Nationalist Age

Alice Tilche

\$30.00S PB / ISBN 9780295749716

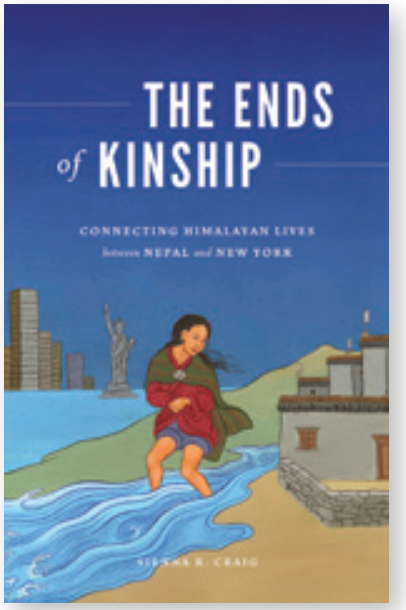

The Ends of Kinship

Connecting Himalayan Lives between Nepal and New York

Sienna R. Craig

$\$ 30.00$ S PB / ISBN 9780295747699

\section{New Lives in Anand}

Building a Muslim Hub in Western India

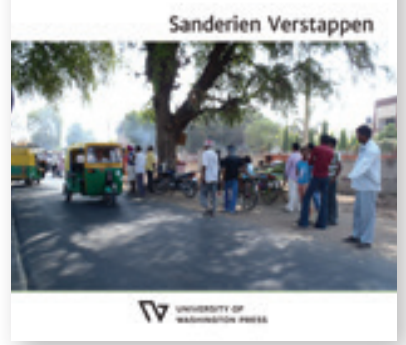

New Lives in Anand

Building a Muslim Hub in

Western India

Sanderien Verstappen

\$30.00S PB / ISBN 9780295749648

OA EDITION / DOI 10.6069/9780295749655

\section{Misreading the Bengal Delta}

Climate Change, Development, and Livelihoods in Coastal Bangladesh

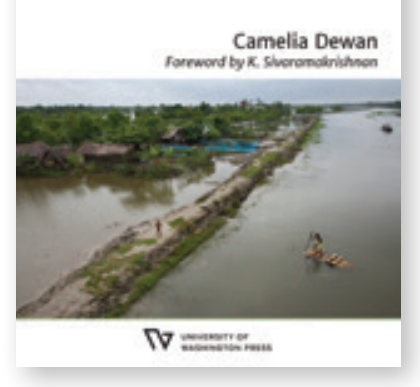

Misreading the Bengal Delta Climate Change, Development, and Livelihoods in Coastal Bangladesh Camelia Dewan Foreword by K. Sivaramakrishnan $\$ 30.00$ S PB / ISBN 9780295749617 OA EDITION / DOI 10.6069/9780295749624 


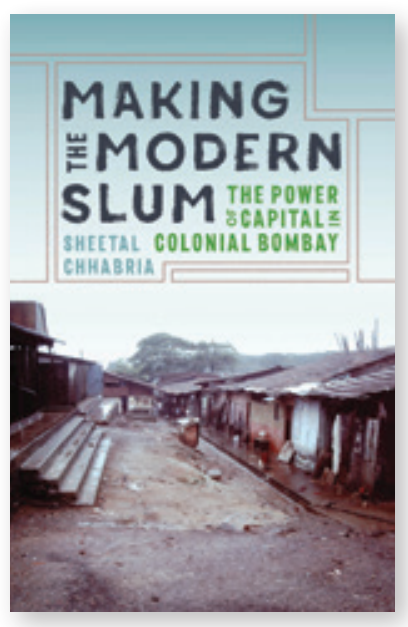

Making the Modern Slum

The Power of Capital in Colonial Bombay

Sheetal Chhabria

$\$ 30.00$ S PB / ISBN 9780295746272

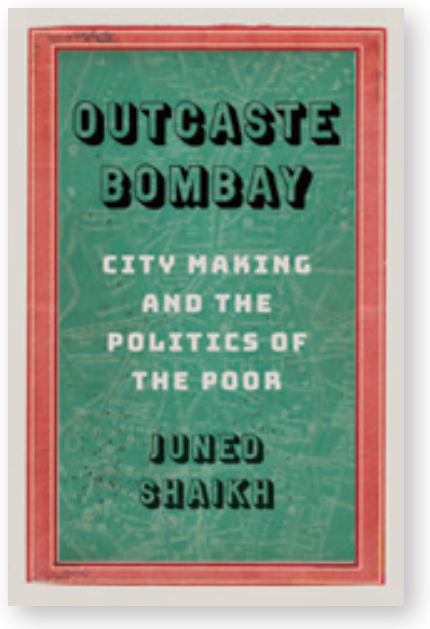

Outcaste Bombay

City Making and the Politics of the Poor Juned Shaikh

$\$ 30.00$ S PB / ISBN 9780295748504

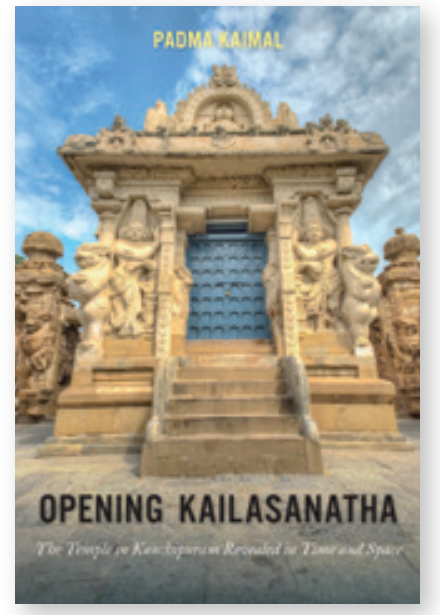

Opening Kailasanatha

The Temple in Kanchipuram Revealed in Time and Space

Padma Kaimal

\$65.00S HC / ISBN 9780295747774
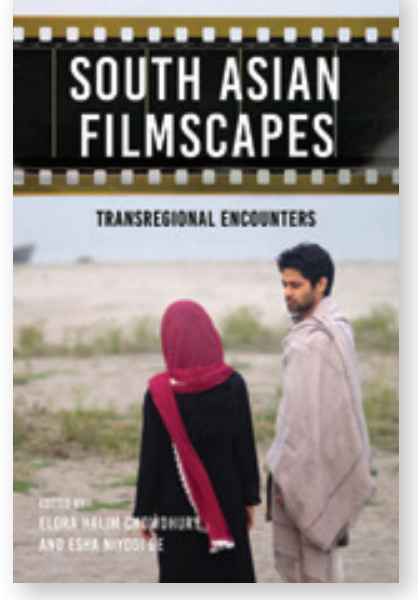

South Asian Filmscapes

Transregional Encounters

Edited by Elora Halim Chowdhury and Esha Niyogi De

$\$ 35.00$ S PB / ISBN 9780295747859

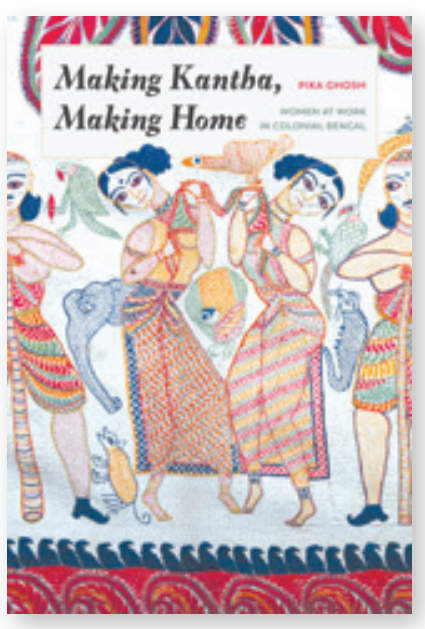

Making Kantha, Making Home Women at Work in Colonial Bengal Pika Chosh

$\$ 65.00$ S HC / ISBN 9780295746999

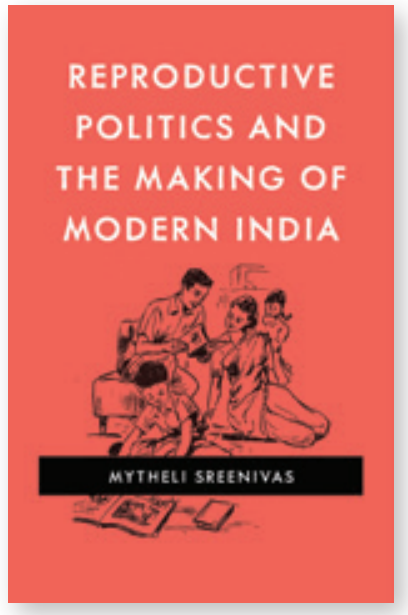

Reproductive Politics and the Making of Modern India Mytheli Sreenivas $\$ 30.00$ S PB / ISBN 9780295748849 TOME OA EDITION / DOI $10.6069 / 9780295748856$ 


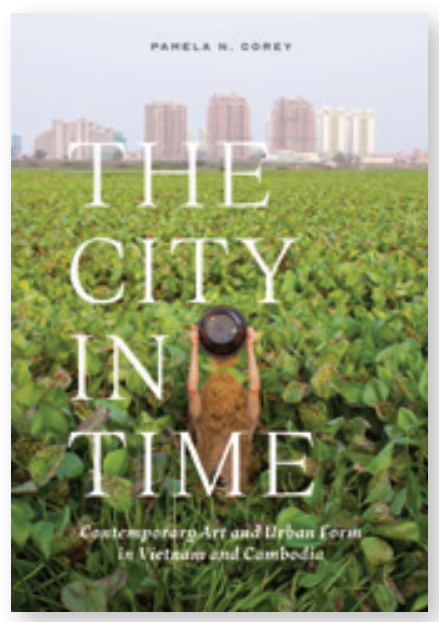

The City in Time

Contemporary Art and Urban Form in Vietnam and Cambodia

Pamela N. Corey

$\$ 65.00$ S HC / ISBN 9780295749235

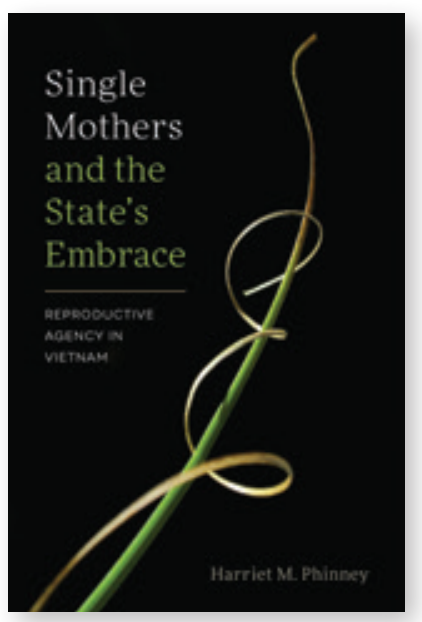

Single Mothers and the State's Embrace

Reproductive Agency in Vietnam Harriet M. Phinney $\$ 30.00$ S PB / ISBN 9780295749433

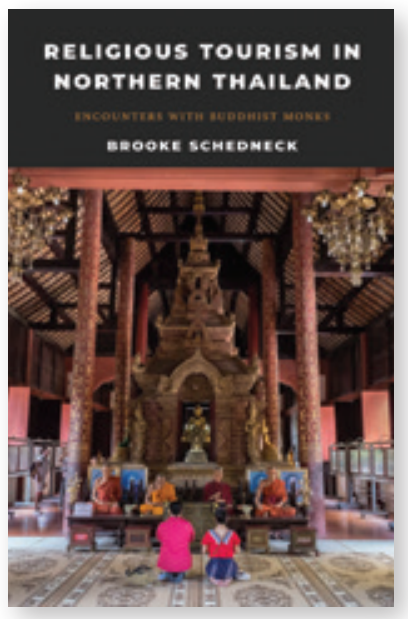

Religious Tourism in Northern Thailand

Encounters with Buddhist Monks Brooke Schedneck \$30.00S PB / ISBN 9780295748924

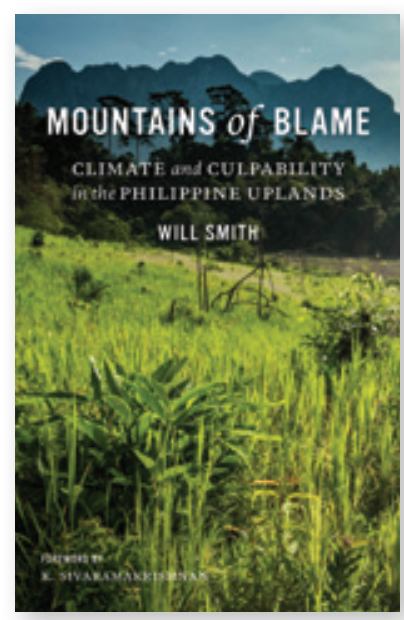

\section{Mountains of Blame}

Climate and Culpability in the Philippine Uplands Will Smith

Foreword by K. Sivaramakrishnan \$30.0OS PB / ISBN 9780295748160

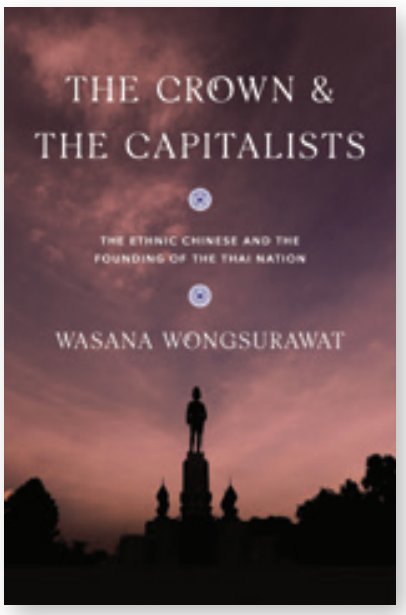

The Crown and the Capitalists The Ethnic Chinese and the Founding of the Thai Nation Wasana Wongsurawat \$30.00S PB / ISBN 9780295746241

Foreword by K. Sivaramakrishnan $\$ 30.00$ S PB / ISBN 9780295746906 


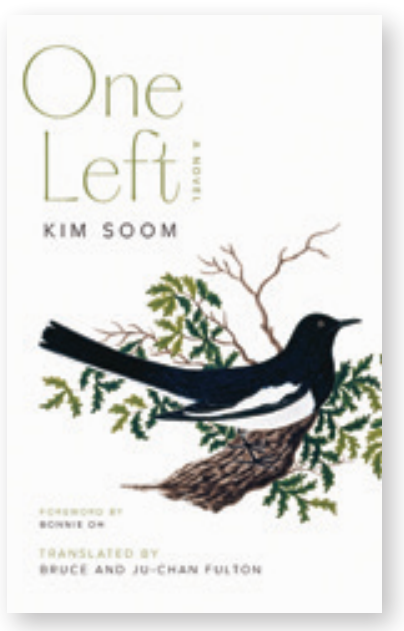

One Left

A Novel

Kim Soom

Translated by Bruce and Ju-Chan Fulton Foreword by Bonnie Oh

$\$ 19.95$ PB / ISBN 9780295747668

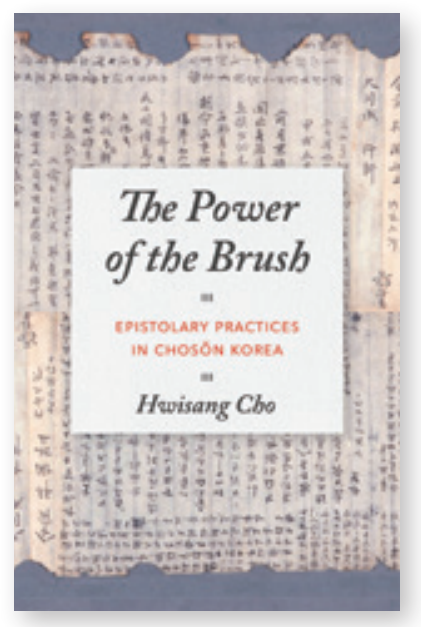

The Power of the Brush

Epistolary Practices in Chosón Korea Hwisang Cho

$\$ 30.00$ S PB / ISBN 9780295747811

TOME OA EDITION / DOI

10.6069 .9780295747828

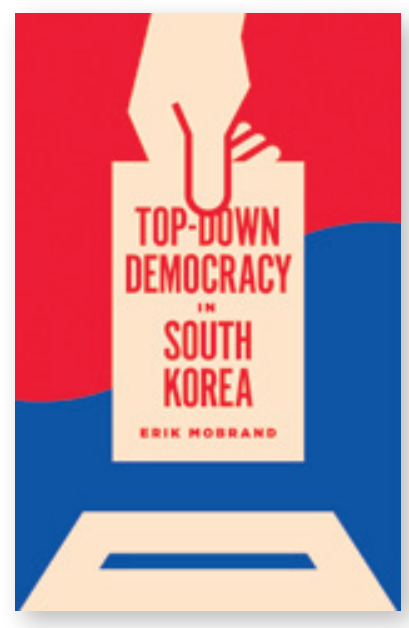

Top-Down Democracy in South Korea

Erik Mobrand

$\$ 35.00$ S PB / ISBN 9780295745473

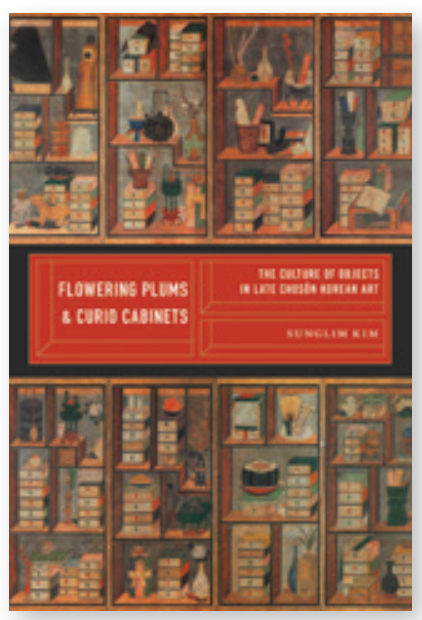

Flowering Plums and Curio Cabinets

The Culture of Objects in Late Choson Korean Art

Sunglim Kim

\$65.00S HC / ISBN 9780295743417

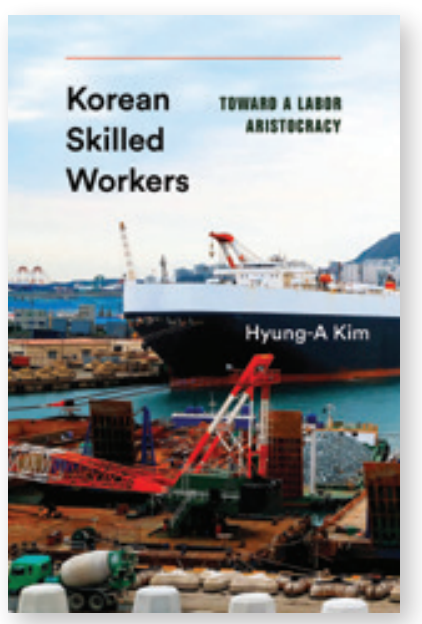

Korean Skilled Workers Toward a Labor Aristocracy Hyung-A Kim $\$ 30.00$ S PB / ISBN 9780295747217 


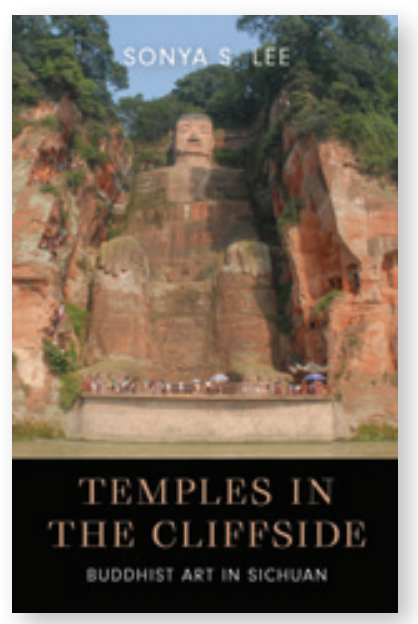

Temples in the Cliffside Buddhist Art in Sichuan Sonya S. Lee \$65.00S HC / ISBN 9780295749303

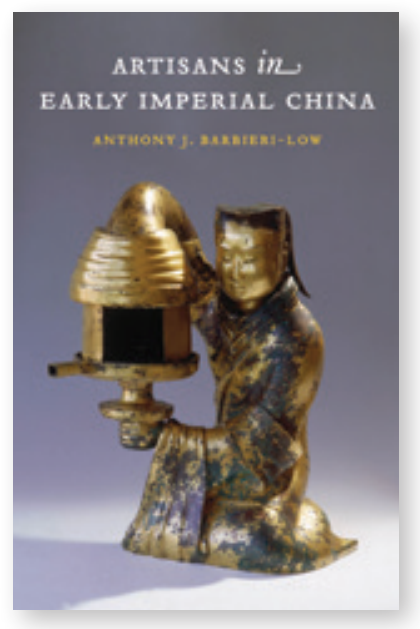

Artisans in Early Imperial China Anthony ]. Barbieri-Low $\$ 40.00$ S PB / ISBN 9780295749389

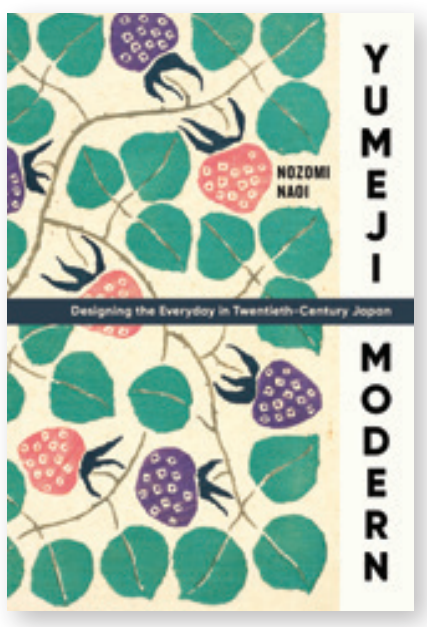

\section{Yumeji Modern}

Designing the Everyday in

Twentieth-Century Japan

Nozomi Naoi

\$65.00S HC / ISBN 9780295746838

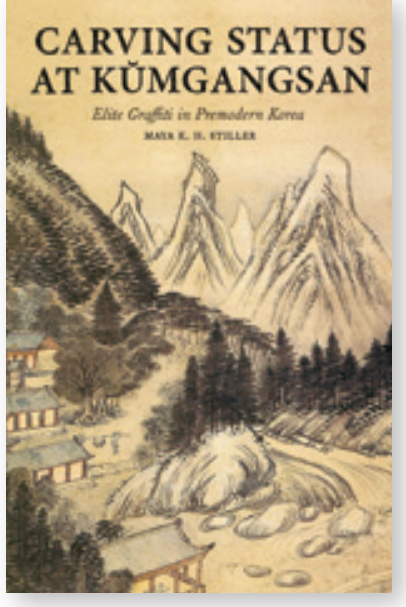

Carving Status at Kŭmgangsan Elite Graffiti in Premodern Korea Maya K. H. Stiller $\$ 65.00$ S HC / ISBN 9780295749259

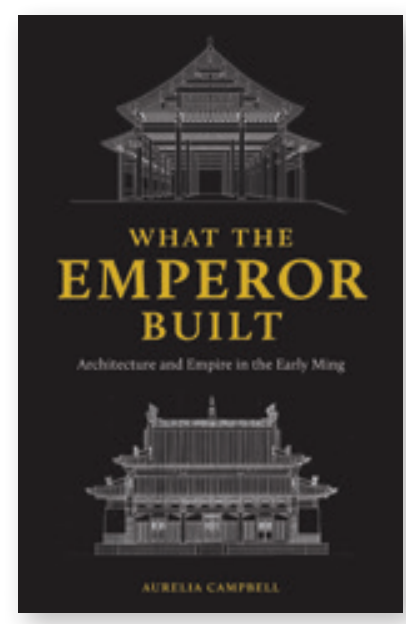

What the Emperor Built Architecture and Empire in the Early Ming Aurelia Campbell $\$ 65.00$ S HC / ISBN 9780295746883

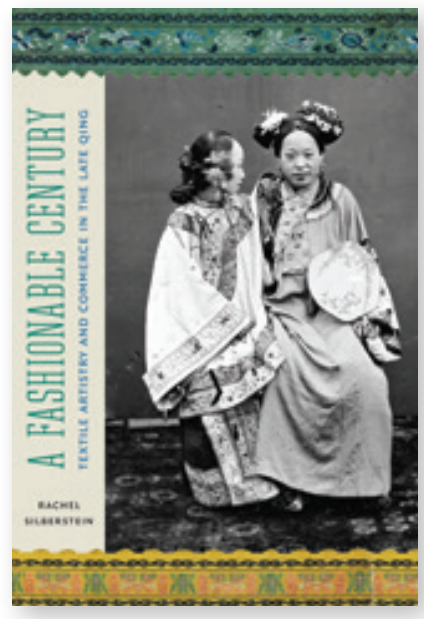

\section{A Fashionable Century}

Textile Artistry and Commerce in the Late Qing

Rachel Silberstein

\$65.00S HC / ISBN 9780295747187 


\section{ORDERING AND SALES INFORMATION}




\section{OFFICES}

University of Washington Press

Box 359570

Seattle, WA 98195-9570

Fax: (206) 543-3932

Email: uwapress@uw.edu

Website: uwapress.uw.edu

\section{HOW TO ORDER}

\section{Individuals}

We encourage you to support your local bookseller. You can also order directly from our website or by contacting our US distributor, Hopkins Fulfillment Services (HFS): Online: uwapress.uw.edu

Phone: (800) 537-5487

Email: hfscustserv@press.jhu.edu

\section{Booksellers}

Our books are represented to bookstores, museum stores, and specialty stores by a dedicated, experienced team of sales representatives in the United States and around the world. Booksellers should contact their local representative to order our titles. To set up an account or order directly, please contact our US distributor, Hopkins Fulfillment Services (HFS):

Phone: (800) 537-5487

Fax: (410) 516-6998

Email: hfscustserv@press.jhu.edu

Mailing address:

University of Washington Press

c/o Hopkins Fulfillment Services

PO Box 50370

Baltimore, MD 21211-4370

\section{GENERAL INFORMATION}

Prices, discounts, and publication dates are subject to change without notice. Our discount schedule is available upon request. For return policies and instructions, please visit our website.

\section{CATALOG DISCOUNT CODES}

Discount codes follow retail prices.

Trade: No mark

Short: $\mathrm{S}$

Text: $x$

\section{EBOOKS}

Digital editions of all titles listed with an EB ISBN are widely available through ebook vendors.

\section{EXAMINATION COPIES}

Examination copies are available at the discretion of the press to qualified instructors of appropriate courses. For instructions on how to request an examination copy, please visit our website.

\section{RIGHTS AND PERMISSIONS}

For inquiries about rights and permission, please contact Beth Fugate at bfuget@uw.edu. Unless otherwise specified, world rights are available for titles listed in this catalog and on our website.

\section{PUBLISHING PARTNERS}

The University of Washington Press distributes books from the following publishing partners:

Art Gallery of New South Wales

Fowler Museum at UCLA

International Sculpture Center

LM Publishers

Lost Horse Press

Lynx House Press

Museum for African Art

National Gallery of Australia

Power Publications

Silkworm Books

UCLA Chicano Studies Research Center Press Sales

Representatives 


\section{SALES REPRESENTATIVES}

\section{PACIFIC NORTHWEST (AK, ID, MT, OR, WA)}

Kurtis Lowe

kurtis@booktravelerswest.com

(206) 932-7865

(800) 440-0818 fax

WEST (AZ, CA, HI, NM, NV, UT)

William Gawronski

wgawronski@earthlink.net

(310) 488-9059

(310) $832-4717 \mathrm{fax}$

MIDWEST (CO, KS, KY, IA, IL, IN, MI, MN, MO, ND, NE, OH, OK, SD, WI, WY)

Kevin Kurtz

kk2841@columbia.edu

(773) 316-1116

(773) 489-2941 fax

MID-ATLANTIC AND SOUTH (AL, AR, DC, FL, GA, LA, MD, MS, NC, SC, TN, TX, VA, WV)

Catherine Hobbs

ch2714@columbia.edu

(804) 690-8529

NORTHEAST (CT, DE, MA, ME, NH, NY, PA, RI, VT)

Conor Broughan

cb2476@columbia.edu

(917) 826-7676

MEXICO, CENTRAL AND SOUTH AMERICA, PUERTO RICO, AND THE CARIBBEAN

US PubRep

Craig Falk

craigfalk@aya.yale.edu

\section{CANADA}

Ampersand represents the press in the Canadian market.

HEAD OFFICE / ONTARIO

Ampersand

Suite 213, 321 Carlaw Avenue

Toronto, ON M4M 2S1

www.ampersandinc.ca

(416) 703-0666

(416) $703-4745$ fax

Saffron Beckwith

saffronb@ampersandinc.ca

(416) 703-0666 Ext. 124

Morgen Young

morgeny@ampersandinc.ca

(416) 703-0666 Ext. 128

Laureen Cusack

laureenc@ampersandinc.ca

(416) 703-0666 Ext. 120

Vanessa Di Gregorio

vanessad@ampersandinc.ca

(416) 703-0666 Ext. 122

Evette Sintichakis

evettes@ampersandinc.ca

(416) 703-0666 Ext. 121

Jenny Enriquez

jennye@ampersandinc.ca

(416) 703-0666 Ext. 126

Kris Hykel

krish@ampersandinc.ca

(416) 703-0666 Ext. 127 
BRITISH COLUMBIA, ALBERTA, SASKATCHEWAN, MANITOBA, YUKON, NUNAVUT, NORTHWEST TERRITORIES

2440 Viking Way

Richmond, BC V6V $1 \mathrm{~N}_{2}$

(604) 448-7111

(604) $448-7118$ fax

Ali Hewitt

alih@ampersandinc.ca

(604) 448-7166

Dani Farmer

danif@ampersandinc.ca

(604) 448-7168

Jessica Price

jessicap@ampersandinc.ca

(604) 448-7170

Pavan Ranu

pavanr@ampersandinc.ca

(604) 448-7165

\section{QUEBEC}

Jenny Enriquez

jennye@ampersandinc.ca

(416) 703-0666 Ext. 126

(416) $703-4745$ fax

\section{ATLANTIC PROVINCES}

Kris Hykel

krish@ampersandinc.ca

(416) 703-0666 Ext. 127

(416) $703-4745$ fax

\section{ORDERS AND CUSTOMER SERVICE IN CANADA}

University of Toronto Press

5201 Dufferin Street

Toronto, $\mathrm{ON} \mathrm{M}_{3} \mathrm{H}_{5} \mathrm{~T} 8$

utpbooks@utpress.utoronto.ca

(800) 565-9533

(800) 221-9985 fax

\section{REST OF WORLD}

Combined Academic Publishers Ltd. represents the press to all areas outside the Americas.

\section{Office Address}

Combined Academic Publishers Ltd.

39 East Parade

Harrogate

North Yorkshire HG1 SLQ

United Kingdom

www.combinedacademic.co.uk

enquiries@combinedacademic.co.uk

+44 (0) 1423526350

+44 (0) 1494581602 fax

George Banbury, International Sales Manager georgebanbury@combinedacademic.co.uk

+44 (0) 1423526350

+44 (0) 7808608836 mobile

Charlotte Anderson, Senior Marketing Executive charlotteanderson@combinedacademic.co.uk

+44 (o) 1423526350

INTERNATIONAL ORDERS

AND CUSTOMER SERVICE

Marston Book Services

160 Milton Park

PO Box 269, Abingdon, Oxon OX14 4YN

United Kingdom

trade.orders@marston.co.uk

+44(0) 1235465500

+44 (0) 1235465555 fax 


\section{TITLE INDEX}

After the Blast $\mathbf{1 2}$

The Art of Ceremony $\mathbf{3}$

Between the Tides in Washington and Oregon 11

Charged 14

Cherokee Earth Dwellers 4

Communist Pigs $\mathbf{1 5}$

The Consolations of Science and Philosophy 44

The Country Where Everyone's Name Is Fear 43

Dale Harding 40

Debating Malthus $\mathbf{1 6}$

Dream Bridge $\mathbf{4 2}$

Emily Carr 36

Everybody 44
Fixing the Image $\mathbf{2 3}$

The Forging of a Black Community 9

Governing Water in India 29

The Great Quake Debate 13

Heritage Drinks of Myanmar $\mathbf{4 1}$

Hilma af Klint $\quad 38$

Iljuwas Bill Reid $\mathbf{3 7}$

In Memory of a Banyan Tree $\mathbf{4 3}$

In the Year of the Rabbit: A Novel 41

Jesintel $\mathbf{7}$

Labor under Siege $\mathbf{1 8}$

Light \& Darkness $\mathbf{4 0}$

The Many Lives of the First Emperor

of China 26

Matisse 39

A Ming Confucian's World 27
New Women of Empire 20

Pioneering Death $\mathbf{1 7}$

Seattle from the Margins 8

Spatial Dunhuang $\mathbf{2 5}$

Spawning Modern Fish $\mathbf{3 0}$

The Swedish Theory of Love $\mathbf{2 2}$

Three Early Mahāyāna Treatises from Gandhāra 34

Three Wooden Trunks $\mathbf{4 2}$

The Tibetan Nun Mingyur Peldrön $\quad \mathbf{2 8}$

Turning Land into Capital $\mathbf{3 3}$

Unsettling Native Art Histories on the Northwest Coast $\mathbf{5}$

Unshaved 21

Upland Geopolitics $\mathbf{3 2}$

Writing Labor's Emancipation

\section{AUTHOR INDEX}

Asaka, Megan 8

Baldissera, Lisa 36

Barbieri-Low, Anthony ]. 26

Berggren, Henrik 22

Boag, Peter 17

Buckley, Christopher 44

Bunn-Marcuse, Kathryn $\mathbf{5}$

Children of the Setting Sun Productions $\mathbf{7}$

Corbin, Luke ]. $\quad 4$

Cramer, Sue 38

Dobkins, Rebecca ]. 3

Dwyer, Michael 32,33

Fahs, Breanne 21

Farris, Katie $\mathbf{4 3}$

Fernandes, Leela $\mathbf{2 9}$

Fleischman, Thomas $\mathbf{1 5}$

Coldbarth, Albert $\quad \mathbf{4 4}$

Grant, Jenna 23

\author{
Hall, Greg 19 \\ Halperin, Mark 27 \\ Harding, Dale 40 \\ Harkin, Terence A. $4 \mathbf{1}$ \\ Hirsch, Philip 33 \\ Hough, Susan 13 \\ Jonaitis, Aldona $\mathbf{5}$ \\ Kaminsky, llya 43 \\ Kelly, Ryan P. 11 \\ Khersonsky, Boris and Ludmila 43 \\ Klinger, Terrie $\mathbf{1 1}$ \\ Lau, Chrissy Yee 20 \\ Lu Rong $\mathbf{2 7}$ \\ Lysheha, Oleh $\mathbf{4 2}$ \\ Mathews, Hannah $\quad 40$ \\ Mayhew, Robert ]. 16 \\ McMaster, Gerald $\mathbf{3 7}$ \\ Melnick Dyer, Alison $\quad 28$
}

Meyer, John ]. 11

Rothenberg, Michael $\mathbf{4 3}$

Schlosser, Andrea $\quad 34$

Schwartz, Harvey $\mathbf{1 8}$

Scurrah, Natalia 33

Shade, Hastings $\mathbf{4}$

Stephen, Ann $\mathbf{4 0}$

Swanson, Heather Anne 30

Taylor, Quintard 9

Teuton, Christopher B. 4

Tkacz, Virlana $\mathbf{4 2}$

Trägårdh, Lars $\mathbf{2 2}$

Turner, James Morton $\mathbf{1 4}$

Verdier, Aurélie 39

Wagner, Eric 12

Woods, Kevin 33

WuHung 25 
